
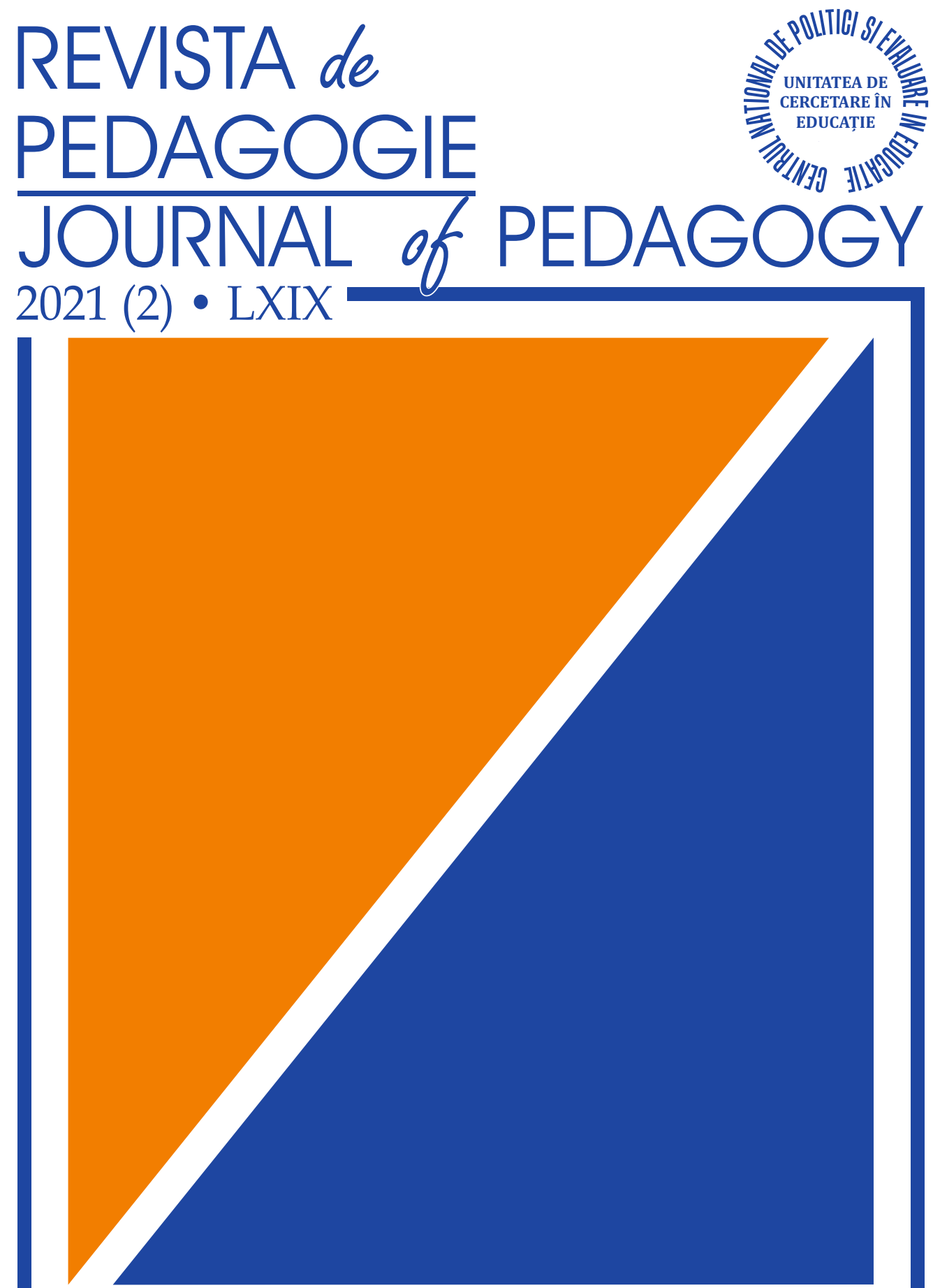
Prof. univ. emerit dr. Viorel NICOLESCU,

Universitatea din București, România

Prof. univ. dr. Constantin CUCOS,

DE

PEDAGOGIE

Universitatea „Al. I. Cuza” din Iași, România

\section{COLEGIUL DE REDACTIE:}

Prof. univ. dr. Gabriel ALBU, Universitatea de Petrol și Gaze din Ploiești, România

Cercet. şt. dr. Otilia APOSTU, C.N.P.E.E. - U.C.E.*, România

Acad. Alexandru BOBOC, Academia Română

Cercet. şt. dr. Laura Elena CĂPIŢ̆, C.N.P.E.E. - U.C.E. ${ }^{*}$, România

Prof. univ. dr. Carmen CREȚU, Universitatea „Al. I. Cuza” din Iași, România

Lector univ. dr. Alina Narcisa CRIȘAN, Universitatea Tehnică din Cluj-Napoca, România

Conf. univ. dr. Roxana ENACHE, vicepreședinte, Asociația „Academia Pedagogilor”, România

Prof. univ. dr. Irfan ERDOGAN, Universitatea din Istanbul, Turcia

Prof. univ. dr. Natasha Angelska GALEVSKA, Universitatea „Chiril și Metodiu” din Skopje, Macedonia

Prof. univ. dr. Dimitrios B. GOUDIRAS, Universitatea „Macedonia”, Salonic, Grecia

Cercet. şt. Atwell GRAHAM, Universitatea din Wales, Marea Britanie

Cercet. şt. dr. Irina HORGA, C.N.P.E.E. - U.C.E. ${ }^{*}$, România

Prof. univ. dr. Violeta MIRCHEVA, Institutul Național de Educație, Bulgaria

Prof. univ. dr. Ioan NEACŞU, Universitatea din București, România

Prof. univ. dr. Rodica NICULESCU, Universitatea „Transilvania” din Brașov, România

Prof. univ. dr. Aleksandra PEJATOVIC, Universitatea din Belgrad, Serbia

Prof. univ. dr. Rossitsa PENKOVA, Universitatea „K. Ohridski” din Sofia, Bulgaria

Lector univ. dr. Ana-Maria Aurelia PETRESCU, Universitatea „Valahia” din Târgoviște, România

Prof. univ. dr. Dan POTOLEA, Universitatea din București, România

Prof. univ. dr. Athina SIPITANOU, Universitatea „Macedonia”, Salonic, Grecia

Prof. univ. dr. Emil STAN, Universitatea de Petrol și Gaze din Ploiești, România

Acad. Alexandru SURDU, Academia Română

Prof. univ. dr. Nikos TERZIS, Universitatea „Aristotel”, Salonic, Grecia

Cercet. şt. dr. Simona Luciana VELEA, C.N.P.E.E. - U.C.E.*, România

Prof. univ. dr. Pavel ZGAGA, Universitatea din Ljubljiana, Slovenia

${ }^{*}$ Centrul Național de Politici și Evaluare în Educație - Unitatea de Cercetare în Educație

\section{RESPONSABIL DE NUMĂR:}

Cercet. șt. III Delia GOIA

\section{REDACTOR:}

Miruna Luana MIULESCU

\section{TEHNOREDACTARE COMPUTERIZATĂ ȘI TIPAR:}

Vlad PASCU

\section{BROȘARE:}

Constantin CHIȚU

Print ISSN: 0034-8678

Online ISSN: 2559-639X

Indexare BDI: CEEOL, Citefactor, Crossref, De Gruyter (IBZ and IBR), DOAJ, EBSCO, ERIH Plus, Google Academic, ROAD și Ulrichweb. Articolele care conțin subiecte despre învățământul superior pot fi indexate și în HEDBIB.

Informațiile și punctele de vedere prezentate în contribuțiile publicate sunt cele ale autorului (autorilor) și nu reflectă neapărat opinia oficială a Revistei de Pedagogie.

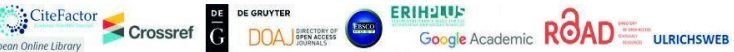

ADRESA REDACŢIEI: Str. Ştirbei Vodă Nr. 37, sector 1, Bucureşti 010102

Tel.: 021-314.27.83 Fax: 021-312.14.47

E-mail: revped@ise.ro Pagina web: http://revped.ise.ro

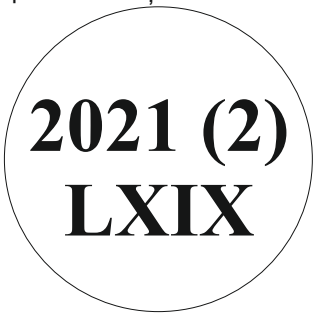




\section{REVISTA DE PEDAGOGIE/ JOURNAL OF PEDAGOGY \\ 2021 (2) - LXIX}





\section{CUPRINS}

\section{$\underline{\text { STUDII }}$}

Copiatul în timpul examenelor online - o trecere în revistă a literaturii de specialitate ...... 7 Adrian NĂZNEAN

Şcoala şi profesorul: schimbări în percep ia elevilor în timpul pandemiei 23

Cristian BUCUR, Laura Elena CIOLAN, Anca PETRESCU

Învă are socială şi emo ională în sala de clasă. Consiliere în şcoală pentru a evita conflictele

Karin SONNLEITNER

Autoeficacitatea şi burnout-ul în rândul profesorilor, în perioada şcolii online 59

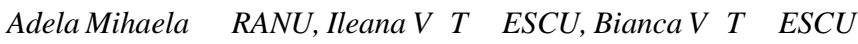

Percep ia profesorilor din învă ământul preşcolar privind asigurarea stării de

bine a copiilor, în context pandemic 79

Mihaela $G U$ U, Simona SAVA

Educa ia online în zonele rurale din România în perioada pandemiei: perspectivele profesorilor 101

Cristina TUNEGARU

\section{RECENZII}

SPERAN A FARCA, DESPRE FRICA DE NECUNOSCUT. Bucureşti, Editura Universitară, 2020, 266 pagini, ISBN 978-606-28-1167-9 121

Oana GHEORGHE

ION ALBULESCU SSI HORA IU CATALANO, e-DIDACTICA.

PROCESUL DE INSTRUIRE IN MEDIUL ONLINE. Bucureşti,

Editura Didactică, 2021, 416 pagini, ISBN 978-606-048-366-3 125

Gina-Florentina TUDORACHE, Mihaela BADEA 
CEDEFOP, INVENTARUL SISTEMELOR ŞI PRACTICILOR DE

CONSILIERE ŞI ORIENTARE PE TOT PARCURSUL VIE II - ROMÂNIA,

CareersNet national records, 2020

Angela ANDREI

$* * *$

Inova ie în consilierea şi orientarea carierei: tendin e interna ionale şi studii de caz

European Training Foundation, Fusun AKKOK, Angela ANDREI,

Florian KADLETZ, Hanna VORONINA, Almira ZAKIYEVA

Evaluarea PISA în România

155 


\section{CONTENTS}

\section{STUDIES}

Cheating during Online Examinations - Literature Review

Adrian NĂZNEAN

The School and the Teacher: Changes in Student Perception during the Pandemic 23

Cristian BUCUR, Laura Elena CIOLAN, Anca PETRESCU

Social and Emotional Learning in Classrooms. Counselling in School to

Avoid Conflicts

Karin SONNLEITNER

Teachers' Self-Efficacy and Burnout during Online School 59

Adela Mihaela ĂRANU, Ileana VĂTĂŞESCU, Bianca VĂTĂŞESCU

The Preschool Teachers' Perceptions on the Children's Well-being in the

Pandemic Context 79

Mihaela $G U$ U, Simona SAVA

Online Schooling in Rural Areas in Romania during the Pandemic:

Teachers' Perspectives 101

Cristina TUNEGARU

\section{REVIEWS}

SPERAN A FARCA, ABOUT THE FEAR OF THE UNKNOWN. Bucharest, Universitara Publishing House, 2020, 266 pages, ISBN 978-606-28-1167-9 121

OAna GHEORGHE

ION ALBULESCU ŞI HORA IU CATALANO, e-DIDACTICA.

THE ONLINE TEACHING PROCESS. Bucharest,

Didactica Publishing House, 2021, 416 pages, ISBN 978-606-048-366-3 125

Gina-Florentina TUDORACHE, Mihaela BADEA 
CEDEFOP, INVENTORY OF LIFELONG GUIDANCE SYSTEMS AND

PRACTICES - ROMANIA, CareersNet national records, 2020

Angela ANDREI

$* * *$

Innovation in Career Guidance: International Trends and Case Studies

European Training Foundation, Fusun AKKOK, Angela ANDREI,

Florian KADLETZ, Hanna VORONINA, Almira ZAKIYEVA

PISA Assessment in Romania 155 


\title{
CHEATING DURING ONLINE EXAMINATIONS - LITERATURE REVIEW
}

\section{Adrian Năznean*}

\author{
George Emil Palade University of Medicine, Pharmacy, \\ Science, and Technology of Târgu Mureş, \\ Petru Maior Faculty of Science and Letters, \\ Târgu Mureş, Romania \\ adrian.naznean@umfst.ro
}

\begin{abstract}
The COVID-19 pandemic forced the closure of many human activities. As a result, education quickly shifted from a classroom setting to an online one, challenging educators and students alike. Multiple issues that had barely been known to educators surfaced: technophobia, lack of rules or guidelines regarding online learning, politeness in a virtual environment, limited social interaction, but some of the greatest challenges remain cheating, and academic integrity concerns during online examinations. Technological and software advances can oftentimes identify cases of academic dishonesty. However, with mass education and faculty unpreparedness it is rather problematic to combat and avoid cheating during online assessment. This mixed-methods review based on the limited empirical research on the topic of cheating during online examinations will identify the factors that lead to cheating and will discuss the best ways of combating and avoiding academic dishonesty.
\end{abstract}

Keywords: academic dishonesty, assessment, cheating, online examination, online learning.

* Lecturer PhD., Science and Letters Department, Petru Maior Faculty of Science and Letters, George Emil Palade University of Medicine, Pharmacy, Science, and Technology of Târgu Mureş, Târgu Mureş, Romania. ORCiD: 0000-0001-9191-6302 


\section{Rezumat}

Pandemia COVID-19 a dus la sistarea multor activită $i$ umane. Drept urmare, procesul educativ a fost transferat din sala de clasă într-un mediul virtual, impunând numeroase provocări atât pentru profesori, cât şi pentru educabili. Există multe probleme care, până în acest moment, nu au fost cunoscute de cadrele didactice: tehnofobia, lipsa regulilor sau ghidurilor privind învă area online, polite ea în mediul virtual, interac iunea socială limitată, însă una dintre cele mai mari provocări este copiatul, o problemă de integritate academică, în timpul examenelor online. Progresele tehnologice şi aplica iile software pot identifica adesea cazurile de fraudă academică. Cu toate acestea, din cauza educa iei în masă şi lipsei de pregătire a cadrelor didactice, combaterea şi prevenirea copiatului în timpul evaluării online este problematică. Această analiză critică limitată a literaturii bazată pe cercetarea empirică despre tema fraudei în timpul examenelor online va identifica factorii care duc la fraudă şi va discuta cele mai bune modalită $i$ de combatere şi evitare a fraudei academice.

Cuvinte-cheie: copiere, evaluare, examinare online, fraudă academică, învă are online.

\section{Introduction}

Although the origin of the proverb one man's meat is another man's poison is unknown, it is attributed to the Roman poet and philosopher Titus Lucretius Carus who was the first to record it in the first century BC. Starting from this proverb, it can be inferred that dishonesty, transgression, or cheating, the focus of our paper, is regarded differently across cultures. Smith (2012) states that there are four main ethical theories which influence ethical perspectives in online classrooms. Whether we regard things from the point of view of subjectivism, cultural relativism, utilitarianism, or Kantian ethics, the dichotomy between right and wrong will always exist. As such, bringing it closer to the topic of our paper, what one student may perceive as dishonesty, another one might simply consider it honest behaviour, as we will prove in the forthcoming sections.

On the other hand, the reasons why students resort to cheating are various. Wenzel and Reinhard (2020) mention test anxiety, social anxiety, stress, parental pressure, to name just a few, the main underlying reasons being 
tests and difficult learning tasks. The authors refer to the rational choice theory and the strain theory according to which students decide whether to cheat or avoid academic dishonesty. Students also cheat in order to get higher marks so as to preserve scholarships or with a view to future internships, employment, etc. They find that the internet is easy to use for cheating and plagiarism, and there is lack of serious consequences if cheating is discovered (Mellar et al., 2018).

In the view of teachers, who are aware of the fact that cheating during online examinations is frequent (Ebohon et al., 2021), there are other reasons why students turn to cheating: not knowing what cheating and plagiarism are, parents' expectations, some students may be employed and have little time to study, the frequency of assessments and the workload that they carry, course content is not presented in an attractive way (Mellar et al., 2018), to name a few.

Ensuring academic integrity has been a challenge ever since the introduction of online teaching and assessment (Farland \& Childs-Kean, 2021) and is currently under investigation in many higher education institutions worldwide.

\section{Cheating in general}

\subsection{Cheating in written exams}

There are many factors that lead to cheating. Personality traits, consciousness, emotional episodes are simply some. While few people would presume that gender influences cheating, there is evidence that different genders have different motivations to cheat (Krou et al., 2021). However, prior to any further comments regarding cheating, we will rely on the definition of Bucciol et al. (2020), namely, "breaking the rules of conduct during a written examination". The meta-analytical approach of Krou et al. (2021) investigated whether gender moderates the relationship between motivation and cheating. The authors found that men cheated more often and had more positive attitudes towards cheating than women.

A study by Mellar et al. (2018) conducted in two universities, one in Bulgaria 
and one in Turkey, analysed the various ways students used for cheating both in examination rooms and in a virtual environment. The authors identified the following methods of cheating in examination rooms: impersonation, copying work from another student, receiving hints from other students, copying from materials, submitting text written prior to the examination, using a communication device to receive help from outside the examination room, giving an excuse in order to temporarily leave the room, plagiarism, and ghost writing. Additional ways of cheating reported by the authors included planting information in the room prior to the examination, using invisible ink, as well as translations from other languages.

Plagiarism, a huge problem in the academic world, implies copying parts of a work without acknowledging the source. Fabrication might frequently accompany plagiarism, that is, falsifying or modifying data and/ or information. Plagiarism, which is more common for take-home examinations, assignments, and homework, and which is the most common form of academic dishonesty among college students (Ampuni et al., 2020), occurs because students need to meet various deadlines and are pressed for time (Kang \& Zhang, 2020). Plagiarism may stretch as far as to the selling of theses (Ampuni et al., 2020). However, various disciplines may have richer sources at risk for plagiarism. Plagiarism may be widely used for essay or thesis writing in humanities and social sciences, whereas it may facilitate the fabrication of information and data in science, technology, engineering, and mathematics (Bucciol et al., 2020). Plagiarism may not only be a cultural perception, but it may also differ across academic disciplines (Denney et al., 2021).

Moreover, other reasons for cheating could be added to our list: students may have a different perception related to cheating, they may fail to understand the rules, they may find the topic too challenging and difficult (Turner \& Uludag, 2013).

According to certain authors, cheating in written examinations takes on various forms (Chirumamilla et al., 2020; Wenzel \& Reinhard, 2020):

- cheat sheets, forbidden aids;

- copying answers in tests;

- inappropriate collaboration: peer collaboration, student-staff collaboration;

- outside assistance; 
- peeking at the answers of other candidates;

- impersonation.

Cheat sheets are answers, possible solutions, paragraphs, essays written before the examination by students to be introduced into the examination room. They might be rather difficult to spot especially when a student's desk is full of other papers (Chirumamilla et al., 2020), but fairly easy to take into the examination room if they are hidden in books, folders, in clothes, or under wrist watches (Bawarith et al., 2017). Cheat sheets are a way of premeditated cheating (Daffin Jr. \& Jones, 2018).

A survey conducted in Australia and the UK by Awdry and Newton (2019) pointed out the fact that students turn to ghost writing, that is, an assignment carried out by someone else or purchased from a website (Mellar et al., 2018), for various reasons: higher education has become transactional, students go to universities to earn a degree, it is difficult to verify the authorship, namely the fact that an essay was purchased rather than written by the student, and also because there is little personalisation of the writing tasks set by the teachers.

\subsection{Online cheating prior to COVID-19}

Teachers are inclined to think that students cheat in online examinations because it does not imply much difficulty, on the other hand, students report that they turn to cheating because they face various learning difficulties (Amzalag et al., 2021).

Conducting assessments online has various advantages, such as lowering costs, several multimedia assessment tools, faster grading of the tests (Vazquez et al., 2021). Student authentication has been in use in the case of online proctored examinations for a few years now and was introduced with the advent of MOOCs (Massive Open Online Courses) and remote education (Atoum et al., 2017). However, it may be of different types. Apart from simple authentication, namely, using a password or answering some security questions, developments in computer science and technology allow biometric authentication as well. Such systems range from the simplest to the most complex ones which include user 
authentication, movement, sound, and keystroke monitoring (Butler-Henderson $\&$ Crawford, 2020), face and voice recognition (Nigam et al., 2021). While the contribution of technology has become essential, the use of it is not the only or most important preventative measure (Mellar et al., 2018).

Mellar et al. (2018) list the five following ways of cheating during online examinations including the submission of assignments: impersonation, communication, copying from materials on electronic devices, plagiarism, and ghost writing. The survey by Chirumamilla, et al. (2020) considered six cheating practices: impersonation, forbidden aids, peeking, peer collaboration, outside assistance, and student-staff collusion in an on-campus controlled setting. Their analysis, conducted in Norway and involving 212 students and 162 teachers, found that only $3 \%$ of students admitted to cheating with the most frequent practices being forbidden aids, peeking, and peer collaboration during on-campus examinations. Moreover, cheating on e-examinations was simpler when students were allowed to bring their own devices. The study also found that peeking was easier in e-examinations than paper-based ones. Another cheating scenario that should not be ignored is that which occurs in asynchronous examinations. Live proctoring in such cases is highly unlikely to be implemented because of the necessity to keep the test open for extended periods of time (Sullivan, 2016) as is the case of MOOCs or LMSs (Learning Management System).

\subsection{Online cheating during COVID-19}

Online examination can take various forms that do not have to replicate inclass testing (Linden \& Gonzalez, 2021). LMSs may have been the most widely used ones prior to the 2019 global pandemic because they can facilitate online formative assessment (Ngqondi et al., 2021). The occurrences of cheating that may arise are sometimes difficult to identify. Apart from the reasons listed above, personal traits, consciousness, age, etc., cheating is also influenced by other characteristics such as gender or nationality. A study by Amzalag et al. (2021) found that younger students and Arab ones cheat more in online examinations. From a statistical point of view, it was found that female players cheated less in online chess competitions during the coronavirus pandemic (Bilen \& Matros, 2021). 
Based on previous research conducted in the field (Amzalag et al., 2021), the authors also identified the three reasons for academic dishonesty in the case of students which can be summarised into: purpose, ability, and costs. Their study categorised the reasons why students cheated during COVID19 examinations into:

- unwillingness to fail;

- dissatisfaction with the lecturers;

- the benefits of dishonest behaviour which surpass the risks of being caught.

Students are more likely to resort to cheating when the tasks they need to complete are difficult and when these are graded, whereas anxiety levels do not rise when assignments are ungraded (Farland \& Childs-Kean, 2021).

The study by Lancaster and Cotarlan (2021) proved that the growth of a market leading file sharing website coincided with the COVID-19 pandemic. File sharing can occur on various websites as free to download assignments, course materials, notes, essays, answers, these services may also be charged or based on exchanges, i.e., the user has to upload a file in order to be able to download another one. Such services are usually cheap and quick and are even legal in certain countries (Awdry \& Newton, 2019). The reasons why students use such essay mills fall under three main categories, which, however, may not be applicable to all geographical regions: dissatisfaction with the teaching and learning environment, the student's language spoken at home, and the multitude of opportunities to cheat (Awdry \& Newton, 2019).

\section{Proctoring}

Test and examination anxiety, as a result of cognitive burden, significantly encourages academic dishonesty of students (Sullivan, 2016). The Reedy et al. study found that both students and staff perceived that lack of supervision is the main factor that provides students with the opportunity to cheat (Reedy et al., 2021). Conducting a randomised control trial, Vazquez et al. (2021) recorded $11 \%$ higher scores in the results of students who took an unproctored examination. Moreover, the Vazquez study also emphasised the fact that differences in the results of proctored and non-proctored examinations were 
smaller when web-based proctoring tools were used versus in-class live proctoring.

According to Nigam et al. (2021), there are three types of online proctoring systems: live, recorded, and automated. Live proctoring, also termed remote proctoring (Linden \& Gonzalez, 2021) happens in real time and it requires a human proctor who is digitally competent. Recorded proctoring, as the name suggests, records the activity of the exam taker, eye movement, object and face detection, whereas automated proctoring implies that the system is able to detect fraud based on different algorithms and technologies.

Various types of digital proctoring systems have already been developed. Such systems rely on the access to the exam taker's web camera and microphone (Nigam et al., 2021). Their development, however, has to consider multiple operating systems as students, generically termed exam takers, may be using an Android, an iOS, or a Windows device. Artificial Intelligence Based Proctoring Systems (AIPS) can be implemented in different types of distance education including MOOCs in order to prevent academic fraud. Such a system delivers the test in a secure browser in order to prevent the student from using other computer resources. It monitors keyboard activity, keystroke dynamics, screen sharing, and, with the aid of the webcam and microphone, the system can detect suspicious student behavior and can bring the image of that particular student to the forefront of a human proctor's screen. Such a system can be cost effective since one human proctor can supervise the activity of many students.

Nevertheless, one important feature in the use of AIPS is the privacy of the students, since their microphones and cameras can be accessed by the system, it could store sensitive data which can be against data protection regulations in various countries. As such, there may be geographical regions in which the implementation of such a system would lead to breaching of the law.

\section{Threats, difficulties, disadvantages of online examinations}

However, distance learning and assessment are not void of disadvantages and threats. Probably one of the greatest impediments that can occur is the 
limited access to a broadband internet connection (Pregowska et al., 2021). Students may find themselves under the burden of stress and anxiety during proctored online examinations (Linden \& Gonzalez, 2021) which leads them to refrain from typing too much, scrolling extensively. A sense of fatigue may arise after having spent months in online education (Pregowska et al., 2021) and, as a result, they may perform poorly in assessments and examinations. The online testing environment negatively affects student performance due to ambient distractions, student discomfort, technical issues, or the impossibility to ask for clarifications if some questions are ambiguous (Fask et al., 2014).

It should not be ignored that teachers may be unfamiliar or inexperienced in online teaching and assessment methods (Ebohon et al., 2021) which can lead to improperly formulated questions or tasks.

It has to be acknowledged that the global pandemic which occurred early in 2020 has had, and with the current $4^{\text {th }}$ wave (as of September 2021), still has serious consequences on the lives of millions of students. A student does not always turn to cheating as a sign of academic dishonesty, but, as previously mentioned, they may be faced with a plethora of problems in their daily lives. The COVID-19 pandemic, which has already made millions of victims, has left families shattered by financial burdens, unemployment, health sequalae, to name just a few. As such, some cases of cheating should be viewed and quantified and qualified through a lens of compassionate perception which should serve as extenuating circumstances. These vulnerable students should be exempt from certain penalties (Amigud \& Pell, 2020) in order to restore and improve their potential of academic behaviour.

\section{Ways of avoiding cheating}

While certain types of assessment may be more effective in an online setting, from the point of view of instant grading, not all of them are suitable if the aim is to prevent students from cheating. Multiple choice questions (MCQs) are fairly easy to be answered (Ebohon et al., 2021), thus, avoiding them is a good measure in preventing cheating during online assessments and 
examinations. However, LMSs allow the randomisation of questions so that the order in which they are displayed to any two exam takers is different. Randomisation and shuffling can be used for MCQs not only to change the order of the questions, but also to change the order of the choices. Although MCQs are associated with a higher likelihood of cheating, randomisation can, however, be used to discourage it (Arnold, 2016). Some LMSs can also generate various types of reports which can enable the measurement of the likelihood of cheating (Chirumamilla et al., 2020). On the other hand, MCQs may not always be conclusive and reflect a greater depth of learning (Darling-Aduana, 2021) and if the teacher uses the same question bank, the students may run the risk of not understanding the study material as they will only memorise the answers to the questions (Golden \& Kohlbeck, 2020). Whenever relying on question banks, teachers should periodically revise and rephrase the answers in order to prevent instances of cheating (Golden \& Kohlbeck, 2020).

Other methods can be employed such as: essays, reports, oral assessments, short answers. Evaluators can devise tests with timed questions so that exam takers do not have the chance to find answers in course materials, on the internet, course notes, etc. (Reedy et al., 2021).

According to Wenzel and Reinhard (2020), taking learning tests after having completed some study materials, but before a final examination has its benefits, however, learning tests can increase levels of anxiety and can be acute stressors. As such, their use should be limited and adapted to the realities and particularities of the course and course participants in line with learning outcomes.

Apart from making assessments more personalised and reflective, teachers can also turn to oral examinations in order to reduce contract cheating. There are other approaches as well to combat occurrences of contract cheating, such as legislation (Butler-Henderson \& Crawford, 2020), which, however, may not apply to all countries.

MOOC providers nowadays, such as Coursera or edX (Indi et al., 2021), Udemy or Future Learn, allow access to a test only after the user has read the terms of it, and selected the agree option. Implementing honour codes may not have the same results in all universities (Ampuni et al., 2020). 
However, to lower cheating levels, such codes have to explain why cheating is detrimental not only for the student, the peers, but also for the society (Bucciol et al., 2020). To have effective results, students should be reminded about honour codes prior to an examination. On the other hand, honour codes may be more effective in face-to-face examinations (Fontaine et al., 2020) than virtual ones.

Abuhammad (2020) hypothesises that the current pandemic period will result in the introduction of new laws, regulations, and solutions regarding education. One solution that might reduce plagiarism and cheating is the training and preparation of both students and their parents for online learning.

Academic integrity plays a crucial role in shaping an individual in terms of profession, society, family, ethical values and principles. As a conclusion of the Amzalag study (2021), the authors recommend instructing students on various ethical principles, encouraging discussions between faculty and students, rebuilding trust via meetings and dialogues.

Another means that would discourage the use of contract cheating services and plagiarism is the use of a plagiarism detection software. Written assignments can be scanned with the aid of such software applications (Beck, 2014) or even web-based ones. Moreover, plagiarism software detectors can also be used to check the understanding of the learned material of students following their submission of a written task (Bdair, 2021).

\section{Conclusion}

As this literature review highlights, cheating in examinations is a frequent occurrence, especially in regard to online ones. From a pedagogical point of view, restoring a healthy academic conduct is the desideratum of future education, whether in a face-to-face or in a virtual environment. Mitigation, dialogue, sometimes even punishment may be a preventative measure to discourage future episodes of cheating and to forestall such behaviour of becoming second nature and to poison the social and professional life of the individual. One key feature of any teacher should be the ability to balance recovery and punishment, but we should also bear in mind that each case 
may have distinct underlying reasons which can explain why the student acted that particular way.

\section{References}

- Abuhammad, S. (2020). Barriers to distance learning during the COVID-19 outbreak: A qualitative review from parents' perspective. Heliyon, 6(11), 1-5. https://doi.org/10.1016/j.heliyon.2020.e05482

- Amigud, A., \& Pell, D.J. (2020). When academic integrity rules should not apply: A survey of academic staff. Assessment \& Evaluation in Higher Education, 46(6), 928-942. https://doi.org/10.1080/02602938.2020.1826900

- Ampuni, S., Kautsari, N., Maharani, M., Kuswardani, S., \& Buwono, S.B.S. (2020). Academic Dishonesty in Indonesian College Students: An Investigation from a Moral Psychology Perspective. Journal of Academic Ethics, 18, 395-417. https://doi.org/10.1007/s10805-019-09352-2

- Amzalag, M., Shapira, N., \& Dolev, N. (2021). Two Sides of the Coin: Lack of Academic Integrity in Exams During the Corona Pandemic, Students' and Lecturers' Perceptions. Journal of Academic Ethics.

https://doi.org/10.1007/s10805-021-09413-5

- Arnold, I.J.M. (2016). Cheating at online formative tests: Does it pay off? The Internet and Higher Education, 29, 98-106.

https://doi.org/10.1016/j.iheduc.2016.02.001

- Atoum, Y., Chen, L., Liu, A.X., Hsu, S.D.H., \& Liu, X. (2017). Automated Online Exam Proctoring. IEEE Transactions on Multimedia, 19(7), 1609-1624. https:// doi.org/10.1109/TMM.2017.2656064

- Awdry, R., \& Newton, P.M. (2019). Staff views on commercial contract cheating in higher education: A survey study in Australia and the UK. Higher Education, 78(4), 593-610. https://doi.org/10.1007/s10734-019-00360-0

- Bawarith, R., Basuhail, A., Fattouh, A., \& Gamalel-Din, S. (2017). E-exam Cheating Detection System. International Journal of Advanced Computer Science and Applications, 8(4). https://doi.org/10.14569/IJACSA.2017.080425

- Bdair, I.A. (2021). Nursing students' and faculty members' perspectives about online learning during COVID-19 pandemic: A qualitative study. Teaching and Learning in Nursing, 16(3), 220-226. https://doi.org/10.1016/j.teln.2021.02.008

- Beck, V. (2014). Testing a model to predict online cheating-Much ado about nothing. Active Learning in Higher Education, 15(1), 65-75. https://doi.org/10.1177/1469787413514646

- Bilen, E., \& Matros, A. (2021). Online cheating amid COVID-19. Journal of Economic Behavior \& Organization, 182, 196-211.

https://doi.org/10.1016/j.jebo.2020.12.004 
- Bucciol, A., Cicognani, S., \& Montinari, N. (2020). Cheating in university exams: The relevance of social factors. International Review of Economics, 67, 319338. https://doi.org/10.1007/s12232-019-00343-8

- Butler-Henderson, K., \& Crawford, J. (2020). A systematic review of online examinations: A pedagogical innovation for scalable authentication and integrity. Computers \& Education, 159. https://doi.org/10.1016/j.compedu.2020.104024

- Chirumamilla, A., Sindre, G., \& Nguyen-Duc, A. (2020). Cheating in e-exams and paper exams: The perceptions of engineering students and teachers in Norway. Assessment \& Evaluation in Higher Education, 45(7), 940-957.

https://doi.org/10.1080/02602938.2020.1719975

- Daffin Jr., L.W., \& Jones, A.A. (2018). Comparing Student Performance on Proctored and Non-Proctored Exams in Online Psychology Courses. Online Learning, 22(1). https://doi.org/10.24059/olj.v22i1.1079

- Darling-Aduana, J. (2021). Authenticity, engagement, and performance in online high school courses: Insights from micro-interactional data. Computers \& Education, 167. https://doi.org/10.1016/j.compedu.2021.104175

- Denney, V., Dixon, Z., Gupta, A., \& Hulphers, E. (2021). Exploring the Perceived Spectrum of Plagiarism: A Case Study of Online Learning. Journal of Academic Ethics, 19, 187-210. https://doi.org/10.1007/s10805-020-09364-3

- Ebohon, O., Obienu, A.C., Irabor, F., Amadin, F.I., \& Omoregie, E.S. (2021). Evaluating the impact of COVID-19 pandemic lockdown on education in Nigeria: Insights from teachers and students on virtual/online learning. Bulletin of the National Research Centre, 45(76), 1-11. https://doi.org/10.1186/s42269-021-00538-6

- Farland, M.Z., \& Childs-Kean, L.M. (2021). Stop tempting your students to cheat. Currents in Pharmacy Teaching and Learning, 13(6), 588-590. https://doi.org/10.1016/j.cptl.2021.01.035

- Fask, A., Englander, F., \& Wang, Z. (2014). Do Online Exams Facilitate Cheating? An Experiment Designed to Separate Possible Cheating from the Effect of the Online Test Taking Environment. Journal of Academic Ethics, 12(2), 101-112. https://doi.org/10.1007/s10805-014-9207-1

- Fontaine, S., Frenette, E., \& Hébert, M.-H. (2020). Exam cheating among Quebec's preservice teachers: The influencing factors. International Journal for Educational Integrity, 16(14). https://doi.org/10.1007/s40979-020-00062-6

- Golden, J., \& Kohlbeck, M. (2020). Addressing cheating when using test bank questions in online Classes. Journal of Accounting Education, 52. https://doi.org/10.1016/j.jaccedu.2020.100671

- Indi, C.S., Pritham, V., Acharya, V., \& Prakasha, K. (2021). Detection of Malpractice in E-exams by Head Pose and Gaze Estimation. International Journal of Emerging Technologies in Learning (IJET), 16(8), 47. https://doi.org/10.3991/ijet.v16i08.15995 
- Kang, X., \& Zhang, W. (2020). An experimental case study on forum-based online teaching to improve student's engagement and motivation in higher education. Interactive Learning Environments, 1-12. https://doi.org/10.1080/10494820.2020.1817758

- Krou, M.R., Fong, C.J., \& Hoff, M.A. (2021). Achievement Motivation and Academic Dishonesty: A Meta-Analytic Investigation. Educational Psychology Review, 33, 427-458. https://doi.org/10.1007/s10648-020-09557-7

- Lancaster, T., \& Cotarlan, C. (2021). Contract cheating by STEM students through a file sharing website: A Covid-19 pandemic perspective. International Journal for Educational Integrity, 17(3). https://doi.org/10.1007/s40979-021-00070-0

- Linden, K., \& Gonzalez, P. (2021). Zoom invigilated exams: A protocol for rapid adoption to remote examinations. British Journal of Educational Technology, 52(4), 1323-1337. https://doi.org/10.1111/bjet.13109

- Mellar, H., Peytcheva-Forsyth, R., Kocdar, S., Karadeniz, A., \& Yovkova, B. (2018). Addressing cheating in e-assessment using student authentication and authorship checking systems: Teachers' perspectives. International Journal for Educational Integrity, 14(2), 1-21. https://doi.org/10.1007/s40979-018-0025-x

- Ngqondi, T., Maoneke, P.B., \& Mauwa, H. (2021). A secure online exams conceptual framework for South African universities. Social Sciences \& Humanities Open, 3(1). https://doi.org/10.1016/j.ssaho.2021.100132

- Nigam, A., Pasricha, R., Singh, T., \& Churi, P. (2021). A Systematic Review on AIbased Proctoring Systems: Past, Present and Future. Education and Information Technologies, 26, 6421-6445. https://doi.org/10.1007/s10639-021-10597-x

- Pregowska, A., Masztalerz, K., Garliñska, M., \& Osial, M. (2021). A Worldwide Journey through Distance Education-From the Post Office to Virtual, Augmented and Mixed Realities, and Education during the COVID-19 Pandemic. Education Sciences, 11(3), 1-26. https://doi.org/10.3390/educsci11030118

- Reedy, A., Pfitzner, D., Rook, L., \& Ellis, L. (2021). Responding to the COVID-19 emergency: Student and academic staff perceptions of academic integrity in the transition to online exams at three Australian universities. International Journal for Educational Integrity, 17(9). https://doi.org/10.1007/s40979-021-00075-9

- Smith, C. (2012). Ethical behaviour in the e-classroom. What the online student needs to know. Chandos Publishing Ltd.

- Sullivan, D.P. (2016). An Integrated Approach to Preempt Cheating on Asynchronous, Objective, Online Assessments in Graduate Business Classes. Online Learning, 20(3). https://doi.org/10.24059/olj.v20i3.650

- Turner, S.W., \& Uludag, S. (2013). Student perceptions of cheating in online and traditional classes. 2013 IEEE Frontiers in Education Conference (FIE), 11311137. https://doi.org/10.1109/FIE.2013.6685007 
- Vazquez, J.J., Chiang, E.P., \& Sarmiento-Barbieri, I. (2021). Can we stay one step ahead of cheaters? A field experiment in proctoring online open book exams. Journal of Behavioral and Experimental Economics, 90. https://doi.org/10.1016/j.socec.2020.101653

- Wenzel, K., \& Reinhard, M.-A. (2020). Tests and academic cheating: Do learning tasks influence cheating by way of negative evaluations? Social Psychology of Education, 23(3), 721-753. https://doi.org/10.1007/s11218-020-09556-0

The online version of this article can be found at: http://revped.ise.ro/category/2021-en/

\section{(CC) BY-NC-BA}

This work is licensed under the Creative Commons Attribution-NonCommercial-ShareAlike 4.0 International License.

To view a copy of this license, visit http://creativecommons.org/licenses/by-nc-sa/4.0/ or send a letter to Creative Commons, PO Box 1866, Mountain View, CA 94042, USA.
Versiunea online a acestui articol poate fi găsită la: http://revped.ise.ro/category/2021-ro/

\section{$(c))$ EY-NC- $Z$ A}

Această lucrare este licen iată sub Creative Commons Attribution-NonCommercial-ShareAlike 4.0 International License.

Pentru a vedea o copie a acestei licen e, vizita $i$ http://creativecommons.org/licenses/by-nc-sa/4.0/ sau trimite i o scrisoare către Creative Commons, PO Box 1866, Mountain View, CA 94042, SUA. 



\title{
THE SCHOOL AND THE TEACHER: CHANGES IN STUDENT PERCEPTION DURING THE PANDEMIC
}

\author{
Cristian Bucur* \\ Laura Elena Ciolan** \\ Anca Petrescu***
}

\author{
University of Bucharest, \\ Faculty of Psychology and Educational Sciences, \\ Bucharest, Romania \\ cristian.bucur@fpse.unibuc.ro,laura.ciolan@fpse.unibuc.ro, \\ anca.petrescu@fpse.unibuc.ro
}

\begin{abstract}
The relationship between the learning environment and the learning behaviours has long been of interest in educational literature. When addressing the socioemotional stages, Erickson raises awareness of the psycho-social influence of school by way of diligence vs inferiority (Harwood et al., 2010), while Galos and Aldridge (2020) explore how designing a learning environment focused on student self-efficacy triggers statistically significant differences in 4 (out of 9) areas of analysis: fairness, task clarity, learning responsibility and task achievement.

The aim of the present study is to highlight the significance and the differences in the main student psychosocial representations of school and teachers before and during the pandemic, the latter being characterised by government-imposed restrictions as well as changes in the student-teacher interaction, both during the second school term of 2019-2020 and the two school terms of the academic year 2020-2021.

The areas we intend to explore are: overall attitude to school and student emotional

* Lecturer, PhD., Teacher Training Department, Faculty of Psychology and Educational Sciences, University of Bucharest, Bucharest, Romania.

** Senior Lecturer, PhD., Teacher Training Department, Faculty of Psychology and Educational Sciences, University of Bucharest, Bucharest, Romania.

*** Lecturer, PhD., Teacher Training Department, Faculty of Psychology and Educational Sciences, University of Bucharest, Bucharest, Romania. Corresponding author.
\end{abstract}


states, the perception on teacher and peer relations, the perception on school as an organisation but also as a learning environment, the parents as a filter on schoolrelated perceptions, and the projective dimension on school life.

The resulting statistical analysis (both nonparametric tests for independent groups and correlation) reveals major changes in the student perception on school and teachers, which will require systematic future intervention, as well as an upgrade of educational strategies, considering that the approaches designed and applied during the pandemic proved unable to compensate for the changes brought about by the restrictions on learning.

Keywords: pandemic, perception, school, student, teacher.

\section{Rezumat}

Rela ia dintre mediul educa ional şi comportamentele de învă are constituie o preocupare activă a studiilor de specialitate. Dacă Erickson, în stadialitatea socio-emo ională, ne sensibilizează asupra influen ei de natură psiho-socială a şcolarită ii prin sentimentul de sârguin ă versus inferioritate (Harwood et al., 2010), Galos şi Aldridge (2020) eviden iază modul în care crearea unui mediu educa ional focalizat pe o creştere a percep iei autoeficien ei în învă are din partea elevilor generează diferen e semnificative statistic pentru 4 (din cele 9) dimensiuni investigate: echitate, claritatea sarcinilor, responsabilitatea învă ării şi orientarea către sarcină.

La rândul său, lucrarea de fa ă urmăreşte să reliefeze semnifica ia şi diferen ele principalelor reprezentări psihosociale legate de şcoală şi cadrul didactic $\hat{\imath} n$ perioada prepandemică versus cea pandemică, ultima fiind caracterizată de restric iile şi modificările de interac iune stabilite de guvern, care au afectat direct semestrul al II-lea al anului scolar 2019-2020 şi ambele semestre ale anului 2020-2021.

Dimensiunile vizate în studiul nostru sunt: stările afective generale şi atitudinea globală fa ă de scoală, percep ia rela iei cu ceilal $i$ colegi, percep ia rela iei cu profesorul, percep ia şcolii ca institu ie şi clădire, părin ii ca filtru al percep iilor fa $\breve{a}$ de şcoală, dimensiunea proiectivă asupra vie ii de şcolar.

Rezultatele analizei statistice (atât diferen $\breve{a}$ neparametrică, cât şi corela ii) ne determină să afirmăm că schimbările produse în percep ia asupra şcolii şi cadrului didactic sunt majore şi vor impune pe viitor atât o interven ie sistematică, cât şi o actualizare a strategiilor educa ionale, în contextul în care cele deja dezvoltate şi aplicate în perioada pandemică nu au putut compensa modificările produse de restric iile de desfăşurare a şcolii.

Cuvinte-cheie: elev, pandemie, percep ii, profesor, şcoală. 


\section{General background}

The changes that took place in education as a result of the Coronavirus pandemic have triggered multiple, multi-level effects, and have become a recurrent topic in academic writing and research, particularly in what concerns the relationship between online learning on the one hand, and student well-being, learning quality, educational methodology and appropriateness of content and evaluation forms on the other hand (Barnett \& Jung, 2021; Onyema et al., 2020; Pokhrel \& Chhetri, 2021; Tsolou et al., 2021).

Faced with difficult choices, the decision-makers had to take on a crucial role in supporting the education provision and to look for the most effective action plans to address the varied challenges of such a large-scale crisis. Currently, the main objective has to do with minimizing the pandemic harm on schools (Saavedra, 2020) and, at the same time, with rebuilding resilient education systems that would be able to restore the safety and confidence in the capacity of education for regeneration for all teachers, students and their families (UNICEF, 2021).

The present context facilitates in-depth exploration and comparative analysis of all cognitive, psycho-social and emotional strata of education before and during the pandemic, with a focus on the changes brought about by the move towards online schooling.

What has changed and to what extent in the student perception of school and teaching staff? How do they see themselves in relation to the school environment and actual space? Has the tendency to digitalize education impacted significantly the overall attitude of learners towards the purpose and importance of school? Can our students (still) feel good in a school setting?

\section{Research methods}

From this point of view, the starting point of the present study was the pandemic as the background against which education has taken place for over a year and a half. The data was collected both before and during the 
SARS-CoV-2 Coronavirus outbreak, which brought major changes in the global lifestyle and significantly impacted the education systems worldwide.

\subsection{Hypotheses}

In our research, we presumed that there are significant differences in the making of teacher representation based on student age, gender, as well as on-site (pre-pandemic) versus on-line learning in pandemic time (as imposed by government restrictions in March 2020). Taking all this into account, our working hypotheses were as follows:

- Teacher representation changes significantly based on student age and gender.

- The psycho-social representations of school are different before and during the pandemic.

As such, we established that our independent variables would be the age and gender of students as well as the nature of their learning experience before and during the pandemic (further referred to as " 2020 "), while the dependent variable would be the two-fold representation of teacher and school.

\subsection{Research tools}

The research tool for data collection was an opinion survey conducted online, using the Google Form application. The questionnaire was structured on 6 different aspects of school and teacher representation: the overall student emotional states and attitude towards school, the students' perception on teacher and peer relations, the students' perception of school as both an organisation as well as a building, parents as a filter of students' perception on school, the projective dimension on school life. We elaborated between 3 to 8 items for each of these peculiar aspects, while the student relationship with their teachers and schools was comprised of 6 open-ended questions:

a. Which is the most important thing that you feel you learned in school?

b. Do you feel understood by your teacher?

c. If anything bad happens to you at school, who do you tell first? 
d. If you could spend more time at school with your teacher(s), how long would that be and what activities would you like to do?

e. What should your teacher do so that you are happier at school?

f. What should your classroom be like so that you are happier at school?

In the present study, we focused exclusively on responses to these 6 openended questions, which are meant to explore the relationship between child or adolescent and both school and learning, typically mediated by teachers. The other aforementioned 5 dimensions were not taken into account for the analysis.

The answers were provided directly by students, as confirmed by the teachers and parents who volunteered to take part in this research, as effective intermediaries between the questionnaire and its actual respondents.

\subsection{Target group}

The questions were answered by Romanian primary and secondary school students, across ages and genders. All the respondents had equal access to online education, in accordance with the emergency measures and the official regulations implemented by the Ministry of Education. After discarding errors and incomplete answers, we ended up with a final number of 793 participants, distributed unevenly into two different groups: pre-pandemic (before March 2020) and pandemic (after March 2020), and sharing the following characteristics:

Table no. 1. Demographics

\begin{tabular}{|c|c|c|c|c|c|c|c|c|c|}
\hline $\begin{array}{c}\text { Age } \\
5-7 \\
\text { years }\end{array}$ & $\begin{array}{c}\text { Age } \\
8 \\
\text { years }\end{array}$ & $\begin{array}{c}\text { Age } \\
9-12 \\
\text { years }\end{array}$ & $\begin{array}{c}\text { Age } \\
13-14 \\
\text { years }\end{array}$ & $\begin{array}{c}\text { Age } \\
15-16 \\
\text { years }\end{array}$ & $\begin{array}{c}\text { Age } \\
16-18 \\
\text { years }\end{array}$ & Female & Male & $\begin{array}{c}\text { Before March } \\
2020\end{array}$ & $\begin{array}{c}\text { After March } \\
2020\end{array}$ \\
\hline 327 & 77 & 267 & 61 & 16 & 45 & 368 & 425 & $\begin{array}{c}297 \\
(193 \mathrm{~F}, 104 \mathrm{M})\end{array}$ & $\begin{array}{c}496 \\
(175 \mathrm{~F}, 321 \mathrm{M})\end{array}$ \\
\hline
\end{tabular}

Ages were grouped based on development traits, anticipating the presumed differences in perception of school and teacher from one age to another. The 
grouping criteria is also relevant from the class level point of view (e.g., 5 to 7 years-olds are in Reception class and 1st grade, taking the first steps into formal schooling), which is consequently related to the teacher, the experience within the group, the specific learning mechanisms and the type of educational activity. However, the investigated lot should not be considered a sample due to the lack of systematic criteria of description and the volunteer-based data collection.

\section{Findings and results}

To begin with, the data analysis involved a qualitative answer analysis as well as generating the categories of psychological significance in the openended answers. These categories were coded and analysed by descriptive and inferential analysis, for each of the 6 items.

The analysis started off with the potential statistical significance of group differences (based on the independent variables and the groups established within them) and was concluded by a descriptive stage, where psychological significance was added to the findings.

\subsection{Inferential analysis}

Based on data specificities, we used nonparametric tests for our inferential analysis, in particular the Kruskal-Wallis test, which was proposed by the preliminary data analysis by Statistical Package for the Social Sciences (SPSS). The cut-off test significance was 0.05. Not all items provided statistical differences and not on all independent variables. The table below describes only the items where statistical analysis rejected the null hypothesis:

Table no. 2. Items and Variables with statistical difference

\begin{tabular}{|c|c|c|c|c|c|c|}
\hline Independent Variable - Item & Item a. & Item b. & Item c. & Item d. & Item e. & Item f. \\
\hline Gender & $>0,05$ & 0,04 & 0,05 & $>0,05$ & $>0,05$ & $>0,05$ \\
\hline Age & 0,00 & 0,00 & 0,00 & $>0,05$ & 0,02 & 0,00 \\
\hline Pre-pandemic - pandemic & 0,00 & 0,00 & 0,00 & $>0,05$ & 0,00 & $>0,05$ \\
\hline
\end{tabular}


As shown in the table, the variables with the biggest differences were age and pandemic-related. The gender variant was statistically significant for only two items:

- Do you feel understood by your teacher?

- If anything bad happens to you at school, who do you tell first?

This first glimpse at results highlights a few initial findings: firstly, that some variables prove more productive in discriminating the changes in how students perceive teachers; these variables are age and pandemic - "2020". It turns out that gender differences only impact to a small extent the representation of student-teacher relations, despite the fact that gender representations are in full development at the ages under analysis.

A major discrimination criterion is undoubtedly age itself, as an expression of development significance at family, social and socio-educational level. This suggests that the impact of student-teacher relations varies wildly from one age group to another, which needs to be analysed further in terms of the psychological relevance it displays.

The second very productive independent variable - the pandemic "2020" - enables us to put forth the finding that the new types of learning activities - other than face to face and most of them changed into online learning have led to significant changes in the representations of school and teacher. Additionally, if we take into account the relatively short time span of this variable enacting change (approximately 6 months), we can notice the unexpected influence on children and adolescents of the ways learning activities are organized and delivered.

The fact that gender, as an independent variable, discriminated so low between the items suggests that the changes and their impact did not rely on whether a student was a boy or a girl; the adaptive resources of both were just as easy (or hard) to permeate. In other words, representations of teachers differ only slightly depending on gender, and the student-teacher relationship is perceived as being as supportive and significant for both male and female students; it is what ensures an integrated, overall development and leads to similar educational achievements, without the hindrance of potential gender discrimination. 
The variable relating to the pandemic - "2020" - does not seem to discriminate at all between the categories of time and activities spent afterschool (item d.), nor does it impact the way the classroom should look like (item f.) This is particularly interesting as it encourages us to notice that the willingness of students to spend additional time with their teachers is not at all connected to the changes in representations that the move online brought about. Similarly, the significance of the classroom for the student is not overwhelmingly influenced by the shift to online learning.

Moreover, neither does the age variable influence the student's willingness to spend additional time with their teacher in school, after class. The difference between the representation of school and teacher, and the representation of after-school and teacher is inconsistent for the student: the school seems to be an all-encompassing concept, while everything else is probably an administrative issue (connected to time, for instance) or a relational one (teacher-student).

\subsection{Qualitative analysis}

Qualitatively, we have analysed the categories of results per item as percentages, so that the effects of participant differences are reduced. Any differences highlighted in each answer category will be in excess of $10 \%$.

\subsubsection{Item a. Which is the most important thing you feel you} learned in school?

The answers to this item varied substantially: answers that mentioned writing and reading were twice as many (26\%) as those mentioning mathematics $(11 \%)$. In between we can find those referring to social and relational development (18\%). Moreover, the differences in percentage are extremely relevant, depending on the variable categories:

- Learning reading and writing, as well as mathematics, scores as the most important gain for over $70 \%$ of students aged 8-12, but barely achieves an overall of 10\% for ages 13-19.

- Students aged below 7 are highly aware of drawing and generally artistic 
skills (71\%), but these become virtually non-existent for students over 14 years old. A similar scenario takes place with teamwork abilities (only scarcely mentioned over the age of $13-26 \%$, and other interests and hobbies $-11 \%$ ). For students over 13 , these categories score a similar percentage with the "I don't know / I can't tell" answer $-27 \%$.

- In terms of gender, there aren't many notable differences in terms of awareness. The only exception is that $67 \%$ of girls seem to be more aware of learning to work as a team in school, compared to only $33 \%$ of the boys. Other than that, we can safely restate the previous idea according to which the representations of male and female students about school and teacher are similar, and teachers do not typically discriminate based on gender.

- Things are remarkably different for the pandemic variable - "2020": there are differences close to $100 \%$ between the students' perception before and during the pandemic. Starting with 2020 , only $36 \%$ of students seem to realise that they learn to read and write in school (compared to $64 \%$ before 2020). The learning of mathematics almost disappears from school representation: it falls sharply from $81 \%$ before the pandemic, to a mere $19 \%$ during 2020. Practical and artistic skills decrease from $65 \%$ by almost half $-35 \%$, while socializing and friends follow a similar pattern. Perhaps the most significant fact is that school representations seem to get de-structured, as suggested by the increase of "I don't know" answers from $27 \%$ to $73 \%$ in 2020 .

\subsubsection{Item b. Do you feel understood by your teacher?}

- Interestingly enough, positive representations of teacher support and empathy seem to increase in primary school from $25 \%$ (ages 5-7) to $32 \%$ (ages 9-12), however they only reach a total of $13 \%$ for other ages. Negative representations of teacher support and empathy hit a peak at 8-, 9-12-, and 13-14-year olds (over 60-70\%).

- Yet again, gender does not seem to inform major difference in the answers of girls and boys, especially when they are phrases as categorical yes/no assertions. There is, however, one notable exception: boys tend to feel less understood overall (66\%), compared to only $33 \%$ of the girls who share this feeling. 
- The pandemic reveals a negative polarization of teacher representations as emotional support and balance, as well as the basis of social exploration. 2020 marks a reduction by half in positive answers (36\% compared to $64 \%$ before 2020 ), while the categorically negative answers more than double (68\% compared to $32 \%$ before 2020 ).

3.2.3 Item c. If anything bad happens to you at school, who do you tell first?

- This item further explores the significance of the meaningful relationship between student and teacher, with the adult support, confidence and representation as a point of reference. It is a relationship that provides safety and attachment to school and specific activities. From the answers, we can notice an overall $47 \%$ of students show trust in their teachers, followed by $16 \%$ who would first tell their mothers and $1 \%$ who would share their misfortunes with their fathers.

- In terms of age, confidence in the teacher is at a peak between 9 and 12 years $(33 \%)$, with a total of $89 \%$ for ages 5-12. By contrast, in the following 7 years (12-19), only $10 \%$ of adolescents would trust their teachers enough. Trust placed in adults decreases dramatically after the age of 13 (from $10 \%$ of students who would reach out to their mothers to $3 \%$, or from $5 \%$ who would reach out to teachers to $4 \%$ ). However, there is an increase in confidence placed in peers (from 15\% to 19\%).

- Hiding emotionally unsettling events seems to be on the increase between 9 and 14 years, with a total of $66 \%$. The high percentage suggests that this is an extremely vulnerable age group, with obvious needs for counselling and socioemotional support. In contrast, only $16 \%$ of students aged 15-19 would keep school adversity as a secret.

In what concerns gender, there are some specific differences, although there are no significant overall discrepancies between male and female representation of trust and safety:

- Girls tend to find it easier to get close to their teachers (56\% of girls would reach out to a teacher compared to $44 \%$ of boys), but they would only seldom rely on their father (only $21 \%$ of girls would reach out to the male primary care, compared to $79 \%$ of boys). Additionally, more girls 
regard peers as significant support than boys (62\% of girls compared to $38 \%$ of boys). The data also reveals the fact that boys tend less to look for external support, relying instead mainly on the father figure $(79 \%$ boys compared to $21 \%$ girls).

In terms of the pandemic variable, the findings reveal, first of all, a substantial decrease in the teacher role for support, together with that of the parents, while the other sources of confidence and safety stay relatively the same as before 2020: the percentage of students that would reach out to a teacher diminishes by half after 2020 (from 68\% before the pandemic to $32 \%$ ). Similarly, the support of the father figure falls sharply from $71 \%$ to $29 \%$, while slightly more students would reach out to their mothers instead (53\% compared to $47 \%$ before the pandemic). Interestingly enough, students stop looking for support in any other school staff - headteacher, other class teachers (there is a stunning change from $100 \%$ to $0 \%$ ), while reaching out to peers also shifts negatively from $57 \%$ to $43 \%$.

3.2.4 Item d. If you could spend more time at school with your teacher(s), how long would that be and what activities would you like to do?

This item was aimed at highlighting the student-teacher relationship and its strength beyond the timetabled classes that one has to attend.

The age variable shows that the willingness to stay for after-school activities is the biggest for ages 9-12. A similar percentage (around 10\%) of students would show the same willingness around age 8 , but that decreases drastically (by up to three to ten times) for ages 13-19. Nevertheless, a significant number of students would be willing to spend their entire day in school (37\%), but only at around 8 years of age. There is also the negative extreme, with a good number of students who are not willing at all to spend extra time in school: $26 \%$ of 8 -year-olds and $29 \%$ of 9-12-year-olds.

Gender seems an interesting variable for this item.

- There are twice as many girls than boys who would be willing to spend their entire day at school (67\% of girls compared to $33 \%$ of boys), even if for those students who are not willing at all to spend extra time in school, gender is almost irrelevant (46\% of girls and $54 \%$ of boys). 
- The most notable are the differences in activities and school subjects that each gender displays: boys are more interested in mathematics and science (75\% compared to only $25 \%$ ), while girls would stay over time to do activities such as painting, modelling or other practical skills (63\% of girls compared to $38 \%$ boys), languages and communication ( $73 \%$ of girls compared to $27 \%$ of boys). An almost equal number of girls and boys would stay longer for physical activities (46\% of girls and $54 \%$ of boys).

What did the pandemic restrictions in learning organisation and delivery bring about? Here are the differences of more than $10 \%$ :

- There is a dramatic fall in the overall student interest in mathematics and science, from $83 \%$ before 2020 to $17 \%$ after that. An identical decrease can be noticed in practical and artistic skills (from $83 \%$ to $17 \%$ ), and a very similar one as well for languages and communication (from $82 \%$ to $18 \%$ ), while the shift of interest in physical activities is reduced from $67 \%$ to $33 \%$.

- Additionally, only $22 \%$ of students would be now willing to spend the entire day at school compared to the $78 \%$ of students before 2020 (prepandemic times), whereas the percentage of students who would not be willing at all to stay overtime stays relatively the same during the pandemic. The same tendency can be noticed among students who would be willing to stay a few hours (3-4 hrs) longer: their numbers drop to half during the pandemic (71\%-28\%, respectively $62 \%-38 \%)$.

- However, there is a steady percentage of students who are willing to stay 1 or 2 hours longer at school (59\% of students before 2020 compared to $41 \%$ after 2020 , respectively $51 \%-49 \%$ ).

We could therefore say that the effect of restrictions on the student's willingness to stay longer in school is the more noticeable the longer the additional times potentially spent with the teacher (there is an average decrease of 50\%). The percentage of students who do not find any motivation to spend extra time in school stays the same as before the pandemic.

3.2.5. Item e. What should your teacher do so that you are happier at school?

The independent variable of age shows that 9-12-year-olds (51\%) would be 
happier if less homework were assigned. Younger students (5-7 years of age) say that their teacher should smile more (32\%), which totals up to $80 \%$ of the answers up to 12 year olds. The need for reading is very significant at $8(33 \%)$, as well as that for play (37\%). Between 8-12 years of age, students seem to feel that they don't understand enough (a cumulative 37\%). As a result, one of the most present needs is for support from their teacher ("I want them to just sit with me").

Of the students who display a sensitivity towards the teacher raising their voice, the peak age seems to be 8 year olds (30\%), while the overall percentage among 5-9-year-olds totals 50\%.

At the same time, an overwhelming 98\% of students who answered they are (already) happy are between 5 and 12 years of age, reaching a peak between 9-12 years old (44\%).

In terms of age, girls seem to feel the need for more fairness (61\% of girls compared to $39 \%$ of boys). Girls also display a more noticeable need to understand more (70\% of girls compared to $30 \%$ of boys) and refer to themselves as happy more often (67\% versus $33 \%)$.

The pandemic - "2020" decreased the need for play (which reaches only $32 \%$ after 2020 compared to the $68 \%$ it scored beforehand); it also diminished the perceived need for rules (15\% post 2020 compared to $85 \%$ before), as well as the need for the teacher to just sit with me (33\% after 2020 compared to $67 \%$ before). Only $30 \%$ of students (less than half in 2020, compared to the $70 \%$ beforehand) still make a mention of teacher raising their voice, but there are also significantly fewer students who feel already happy (30\% in 2020 compared to $70 \%$ before).

\subsubsection{Item $f$. What should the classroom be like so that you are} happier at school?

The last research item explores the significance of the classroom, which is frequently and heavily influenced by the personality of the teacher and the nature of the relationship between teacher and student. 
We started by considering what the various representations of the classroom are for different age groups, as an extension of teacher personality and school's organizational profile, and we were able to identify the following:

- for 5-7-year-olds, it is important that the classroom is colourful (33\%) and beautiful (34\%);

- for 8 -year-olds, the room must be beautiful $(38 \%)$ and have a lot of visuals $(42 \%)$;

- for 9-12-year-olds, the most important is that the room be clean and tidy (48\%), a place of happy relationships, friends and understanding (38\%);

- most 13-19-year-olds also refer to tidiness, cleanliness and quality relationship. It must also be mentioned that many answers for this age group specify equipment and facilities as being important (22\% in total).

In terms of gender, most girls seem to prefer a colourful classroom (60\% of girls compared to $40 \%$ of boys) and focus more on harmonious relationships ( $57 \%$ of girls compared to $43 \%$ of boys). In other respects, there are only minor differences around $10 \%$.

The pandemic variable generated a significant decrease in all aspects connected to the student perception of the classroom, the most obvious of which refer to the room being beautiful (mentioned by only $34 \%$ of students compared to $66 \%$ before 2020), images and fairies (29\% compared to $71 \%$ before 2020$)$, nicely decorated (34\% compared to 66\%), clean and tidy (39\% compared to $61 \%$ ). The results provide fertile ground for future research on the differences between the physical learning environment and the virtual classrooms of online education.

\section{Discussion}

The findings of this study have to be seen in light of some limitations. First, the study focused on two different groups (pre-pandemic and pandemic) in terms of age and gender distribution, with no analysis of urban/ rural disparities. Second, not all age groups had the same consistency level; for some of them, the low number of valid recorded responses impedes on the strength of evidence in favour of our research hypotheses. 
Nevertheless, the analysis clearly points out that the restrictions on educational activities have had a considerable impact on how students relate to both teachers and the school as whole. Despite their relatively short duration of enforcement, the pandemic-related constraints have reverberated in the chief aspect of school life (by way of comparison, a similar educational shift, the Reception/ Preparatory class year, needed to benefit from years of teacher training, as well as systematic action on parents and students alike).

Our research results show once more that the mental representations of teachers change significantly with the student age, the most sensitive of whom are 9-12-year-olds, who are particularly dependent on their interaction with the teacher.

Furthermore, the student gender influences only partially and to a small extent their mental representation of their teacher, which at the same time highlights the teachers' ability to treat students as developing beings rather than girls or boys who act in specific roles - which comes to show that gender discrimination is virtually non-existent.

There are, however, a few essential elements that need to be addressed by teachers and educational managers and which require immediate, even if not systemic, intervention.

- Student gender determines different needs.

Girls seem to need:

- a physical space that is well equipped and psychologically safe and warm;

- more playful interaction with the teacher;

- their learning organized in different ways, since they feel certain tasks and subjects are more difficult;

- more teamwork.

At the same time, the girls' answers point to the fact that they are happier at school.

As for boys, they:

- feel (almost twice as) pressured by the amount of learning hours and work; 
- state that they "aren't understood" by teachers, which augment maladaptive behaviours and weaken the psycho-social mechanisms that would motivate and mobilize them.

- Student age influences the student relationships with their teacher and peers.

- Even a significant percentage of 5-7 and 8-year-olds state they feel alone and unsupported in various learning tasks, which leads to a negative separation between students and learning activities, as if they are constantly tested against standards they do not quite grasp and therefore don't know how to succeed.

- The teaching style, the quality of the relationship with the teacher and a supportive attitude seem to matter more to 5-7 and 8-year-olds.

- Similarly, peer relationships prove to pose a problem to 9-year-olds, which later decreases from $55 \%$ to $28 \%$.

- Students in the 5-7- and 8-years age groups seem more sensitive to how well equipped the physical space is and how attractive it is, displaying at the same time a substantial need for alternative activities.

- Almost every other student between 6 and 8 years of age would like their teacher to use a softer voice $(52 \%)$ and would need more help to understand things (49\%).

- Every third student between 6 and 8 years of age says they would like their teacher to smile more.

- There is a notable polarisation between students who realise the value of school and learning, and those who are thoroughly under-motivated. This leads to the idea that building and developing an awareness of the importance of education, as well as the efforts that assist this process, have already been established prior to this age and work autonomously further on.

- During the pandemic, there are twice as many students who feel burdened by homework and school activities, over a very short time (one year).

- Many of the students who participated in our study have explicitly stated the need for their teacher to be closer to them and engage in shared activities, which suggests they might have felt abandoned in the face of academic difficulties and issues. Overall, there is an enhanced need for a different kind of learning and teaching, with fewer subjects and less pressure to perform. 


\section{Conclusion}

The results of our research confirm that the measures imposed in the context of the 2020 pandemic have substantially altered the national educational landscape. Besides the age and gender specific needs that were also part of this study, we believe it is essential to consider future interventions that would minimize the harmful effects of the changes brought about by the pandemic, as well as to develop educational programmes that will be suited to the current context. The future of post-pandemic education will depend to a great extent on understanding a new educational paradigm, as well as on the systemic capacity to view these challenges as just as many development opportunities.

\section{References}

- Barnett, W.S., \& Jung, K. (2021). Seven Impacts of the Pandemic on Young Children and their Parents: Initial Findings from NIEER's December 2020 Preschool Learning Activities Survey. National Institute for Early Education Research.

- Galos, S., \& Aldridge, J.M. (2020). Relationships between learning environments and self-efficacy in primary schools and differing perceptions of at-risk students. Learning Environments Research, 24(1), 253-268. https://doi.org/10.1007/s10984-020-09323-0

- Harwood, R., Miller, S.A., \& Vasta, R. (2010). Psihologia copilului. Polirom.

- Onyema, E.M., Nwafor, C.E., Obafemi, F.A., Shuvro, S., Fyneface, G.A., Aabha, S., \& Alhuseen, O.A. (2020). Impact of Coronavirus Pandemic on Education. Journal of Education and Practice, 11(13), 108-121.

https://doi.org/10.7176/JEP/11-13-12

- Pokhrel, S., \& Chhetri, R. (2021). A Literature Review on Impact of COVID-19 Pandemic on Teaching and Learning. Higher Education for the Future, 8(1), 133-141. https://doi.org/10.1177/2347631120983481

- Saavedra, J. (2020). Educational Challenges and Opportunities of the Coronavirus (COVID- 19) Pandemic. World Bank Blogs.

- Tsolou, O., Babalis, T., \& Tsoli, K. (2021). The Impact of COVID-19 Pandemic on Education: Social Exclusion and Dropping out of School. Creative Education, 12, 529-544. https://doi.org/10.4236/ce.2021.123036

- UNICEF (2021). Building Resilient Systems beyond the COVID-19 Pandemic: Second set of considerations for school reopening. UNICEF Europe and Central Asia. 
The online version of this article can be found at: http://revped.ise.ro/category/2021-en/

\section{(cc) EY-NC-SA}

This work is licensed under the Creative Commons Attribution-NonCommercial-ShareAlike 4.0 International License.

To view a copy of this license, visit http://creativecommons.org/licenses/by-nc-sa/4.0/ or send a letter to Creative Commons, PO Box 1866, Mountain View, CA 94042, USA.
Versiunea online a acestui articol poate fi găsită la: http://revped.ise.ro/category/2021-ro/

\section{(cC) DY-NC-SA}

Această lucrare este licen iată sub Creative Commons Attribution-NonCommercial-ShareAlike 4.0 International License.

Pentru a vedea o copie a acestei licen e, vizita $i$ http://creativecommons.org/licenses/by-nc-sa/4.0/ sau trimite i o scrisoare către Creative Commons, PO Box 1866, Mountain View, CA 94042, SUA. 


\title{
SOCIAL AND EMOTIONAL LEARNING IN CLASSROOMS. COUNSELLING IN SCHOOL TO AVOID CONFLICTS
}

Karin Sonnleitner*

University of Graz,

Center for Social Competence and Institute of the Foundations of Law,

Graz, Austria

karin.sonnleitner@uni-graz.at

\begin{abstract}
Heyse \& Erpenbeck (2009) define counselling competence very broadly as the ability to counsel people and organisations. This requires for teachers an extensive knowledge of content, social-emotional competence and solution-oriented thinking. In this context, the article focuses on the one hand on the location of the legal basis for teacher training in higher education in the context of counselling competence and how counselling skills can be improved to avoid conflicts in the classroom. On the other hand it describes the handling and use of counselling skills in everyday school life based on the results of focus group discussions within the Erasmus+ project SEEVAL.
\end{abstract}

Keywords: conflicts in school, content analysis, counselling, focus groups, social emotional learning.

\section{Rezumat}

Heyse şi Erpenbeck (2009) definesc competen a de consiliere într-un mod foarte larg ca fiind capacitatea de a consilia persoane şi organiza ii. Aceasta solicită din partea profesorilor cunoştin e extinse de con inut, competen e socioemo ionale şi o gândire orientată pe solu ii. In acest cadru, articolul se concentrează pe de o parte pe identificarea bazei legale privitoare la formarea

* Senior Lecturer, Center for Social Competence and Institute of the Foundations of Law, University of Graz, Graz, Austria. 
profesorilor în învă ământul superior, în ceea ce priveşte competen a de consiliere. Pe de altă parte, articolul descrie utilizarea competen elor de consiliere $\hat{\imath} n$ via a şcolară curentă, cu referire la rezultatele discu iilor din cadrul focus-grupului realizat in proiectul Erasmus + SEEVAL.

Cuvinte-cheie: analiză de con inut, conflicte în şcoală, consiliere, focus grup, învă are socio-emo ională.

\section{Introduction}

Since counselling is broadly defined as the ability to counsel people and organisations (Heyse \& Erpenbeck, 2009), counsellors and teachers alike need an extensive knowledge of content, social emotional competence and solution oriented thinking. Due to social changes, growing complexity and the loss of reliable structures, the need for counselling in schools is increasing. Consequently, teachers not only counsel pupils, but also need guidance themselves in order to cope with the diverse tasks. In this context, the following questions arise: how they deal with conflict situations in the classroom and what changes are needed to enable a better implementation of social and emotional learning in school.

The education of teachers for primary and secondary education has been fundamentally reformed in the recent years in Austria. The most visible innovation is the introduction of a four-year bachelor's degree programme, followed by a master's programme lasting at least one or two years. There are four network regions between universities/colleges for teacher education in Austria. The Austrian Federal Framework Law on the Introduction of a New Education for Pedagogues, which was enacted in 2013, stipulates in $\S$ 42 (1a) that the curricula of bachelor's and master's degree programmes for obtaining a teaching profession must be competence-based and include the teaching of general and special pedagogical competences, subject-specific and didactic competences, inclusive and intercultural competences, social competences, counselling competences and professional understanding. In the now applicable paragraph, different competences are still implemented in the curricula.

In this context, it is worthwhile to clarify: the meaning of counselling 
competencies for conflict management in the context of social emotional learning; then how social and emotional learning be integrated in school, which methods to use and what changes to plan for. Finally, two practical tools are provided for teachers to use directly in the classroom.

\section{Improving counselling competences to avoid conflicts}

In everyday school life, the teaching staff must act in a counselling capacity at various levels, for example in parental work, with other teachers and school children (Drechsel et al., 2020; Gartmeier, 2019). The focus will be on the classroom with all its conflicts, where teachers should convey security, show professional competence and signal empathy in order to impart social emotional learning to the students (Grewe, 2015; Palzkill et al., 2015; Schnebel, 2017). Social emotional learning is a process in which children and adults acquire and effectively apply the knowledge, attitudes and competencies to understand and manage emotions, set and achieve positive goals, feel and show empathy for others, build and maintain positive relationships and make responsible decisions. So, there are lots of aspects, which teachers have to observe. The five areas - self-awareness, self-management, social awareness, relationship skills and responsible decision-making - are fundamental to social emotional learning (CASEL, 2017).

All areas are important to diagnose and solve conflicts. Conflicts often have negative connotations, yet they hold great potential. Aconstructive approach to conflicts leads to further developments in the classroom. To achieve this progress, however, a systematic approach to the topic is necessary (Sonnleitner \& Gschweitl, 2021). Lessons, in which social emotional learning takes place are suitable to teach pupils different ways to systematically and constructively analyse, diagnose, manage and solve conflicts.

\section{Method}

Building on this theoretical background, focus group discussions were conducted within the framework of the international project SEEVAL (Social and Emotional Education - Building Inclusive Schools and Ownerships of 
Values). A focus group is "a carefully planned discussion designed to obtain perceptions on a defined area of interest in a permissive, nonthreatening environment" (Krueger \& Casey, 2009, p. 2). With this kind of qualitative research, the outcomes are in-depth information about the daily problems and challenges (Danner et al., 2018). Multiple participants explain their own standpoint in a simultaneous discussion so that the outcome is - in the best case - a broad range of issues and more than the outcome of an individual interview with a single participant (Cyr, 2019). The number of participants depends on the purpose and the goal (Vaughn et al., 1996). At the beginning of the focus group, an opening question is asked to get the discussion going. Questions aiming at factual information are a good choice. This is followed by introductory and transitional questions that introduce the topic. Key questions are at the centre of the discussion and address the actual research questions. Concluding questions summarise and give the facilitator reassurance that he/ she has understood the participants well (Schulz et al., 2012).

The purpose of the SEEVAL-study is to set up a training programme to develop the educators' social and emotional competences for the classroom learning. For this purpose, best practices and methods from Europe will be collected and guidelines will be developed. In the three focus groups we collected and analysed information about needs and perceptions on social and emotional learning in schools.

WUS Austria (2021) and the Center for Social Competence (2021) at the Graz University invited teachers and school psychologists working with children aged 12 to 18 as well as teachers from universities and university colleges for teacher education.

Among the participants of all three focus groups were schoolteachers (13) and school psychologists (2) as well as teacher trainers from universities (1) and university colleges for teacher education (5). The focus group discussions lasted between 80 and 90 minutes each. Experience in social emotional learning was a precondition for participation.

The focus groups were recorded, transcribed and finally paraphrased following the qualitative content analysis of Mayring (2015). All responses remain anonymous. 
The following chapters contain the results of the content analysis.

\section{Results}

To reach the purpose we asked the 21 persons the following questions:

1. How is social and emotional learning integrated in their school and what does teaching look like?

2. What specific practices, methods, books, materials are used?

3. What changes are needed to enable a better implementation of social and emotional learning in school?

\subsection{Integration of social emotional learning in school}

The interview partners were asked how social and emotional learning is integrated in their school and what does teaching look like?

In the majority of schools one hour a week, mostly in the first hour on Monday, the children have the opportunity to strengthen their interaction with each other, to observe themselves, to exchange ideas and to work on conflicts in the social emotional learning lesson. Besides, in three schools social and emotional learning is even part of the school mission statement and has been institutionalized as a subject, which has an effect outside of the lesson provided for it. If necessary, this lesson can be extended to the following second lesson.

But the curriculum is in the foreground and the teachers would like to have more time to bring in social aspects. So, one or two hours are too few in view of the large range of topics. The interview partners are sure that social emotional learning lessons are extremely important and meaningful and there are still enough conflicts that take up a lot of time.

The teachers focus on personality development and want to strengthen the individuality and togetherness with for example a strength's portfolio or a class climate conference. Such a conference can be convened by pupils, parents and teachers in case of conflicts, in which conflicts are discussed. 
They also train buddies and peers. The buddies are pupils who accompany new pupils and make it easier for them to get started and arrive at the new school. There is a special training for the peer mediators, in which conflict strategies are learned so that the pupils are able to solve minor conflicts themselves without adult intervention and to support conflict resolution. One teacher describes that in his school the introductory seminar is held by school social workers.

Further trainings include non-verbal and non-violent communication as well as conflict resolution strategies. Moreover, for example, courses in personality development, communication, coaching, social learning, human dignity and human respect are offered at the university. Many teachers name the concept of non-violent communication (NVC), in which the focus is on empathy, self-empathy and on connecting, appreciative communication. NVC is offered as an elective subject for primary and secondary education as well as for vocational education. One opportunity to expand the social and emotional competences are project days.

One teacher points out that social and emotional learning is not only a subject, but also firmly integrated in the regular lessons. It happens every day and really every hour. In the first school year, the focus of social learning is on oneself, getting to know one's own strengths and weaknesses: pupils are strengthened where they can be strengthened. In the second school year, social learning focuses on the group. It is about learning acceptance meaning that everyone is good and okay the way they are. Then, in the third school year, the focus is on teamwork, and in the fourth grade on career orientation. One teacher emphasises that with regard to the topic of social emotional learning in his school there are officially no lessons, no value units, nothing at all. However, if necessary, the head-master agrees to deal with conflicts or problems outside the lesson. Having no lessons is a problem in general. Another teacher mentions a special example: In her school the hour, which is provided for social emotional learning, is split with the subject of computer science. So, the lesson never takes place with the whole class and doesn't make sense, because individual topics often cannot be finished or work processes have to be interrupted or aborted.

In another school a time-out concept is implemented in which the teaching 
staff has the opportunity to send conspicuous children out of class so that a colleague who has developed the concept can talk to the pupil about the conflict. Appropriate documentation and scoring take place. One teacher explains compulsory events in the area of social and personal competence. The students deal with their attitudes and values with regard to various focal points (e.g., multilingualism, migration, human rights education). These events take place within the framework of group coaching.

\subsection{Methods Being Used}

The following question was asked about the category of materials, practices and methods: What specific practices, methods, books, materials on social and emotional learning are used?

No matter which method is used, the main thing is that it is used in an authentic manner. Two teachers express their preference for emotional pattern cards. In one school there exists a method pool to choose from. The teaching staff can choose for themselves what they can work well with, because not everyone is comfortable with everything. The choice of methods should be individually adapted to the class. If someone wants to incorporate social and emotional learning in the classroom, they will definitely do it.

Most of them use methods, which they have acquired through participation in further training. They underline the importance of such a pool of material and mix those methods with classic lesson plans, which give a certain security at the beginning, especially for teachers who are afraid of teaching social and emotional learning. It is important to have room for play, conversation and exercises. There are certain subjects where there is always room and other subjects where it is very difficult. 
Table no. 1. Methods being used

\begin{tabular}{|l|l|l|}
\hline apps & full text documents & role plays \\
\hline change of perspective & group work reflection & slide sets \\
\hline cooperation games & learning games & sports community games \\
\hline countless books & lists of needs and feelings & theatre methods \\
\hline digital media & nonviolent communication & various power point \\
\hline discussions & online materials & working with impulses \\
\hline experiencing silence & paraphrasing & world café \\
\hline
\end{tabular}

They also use meditation exercises to experience silence. Coaching conversations are another method. The conversation always takes place at the end of the semester. Pupils can talk to teachers at eye level, which fosters the relationship level. As another method, one teacher mentions the strengths pass with a focus on strengths work. This is created with the involvement of parents, siblings or other persons who name the students' strengths. The children simply learn to know their strengths, also to know their weaknesses and to learn to talk about themselves. The teachers also recommend various books like "Solving Conflicts Yourself" by Kurt Faller or the Handbook for Human Rights Education by Wolfgang Benedek, the Berlin-Brandenburg "Anti-Bullying Primer" or "Dealing with Conflicts NonViolently" or "Mediation in Schools" by Jamie Walker. Materials from the University of Vienna, the POLIS Centre and materials from Özeps are also used.

Another aspect is the exchange among teachers. Also, the networking between different school systems or systems and organizations are very important. One teacher has exchange meetings with colleagues and a two-day training to increase the pool of materials. One teacher adds the topic of reflection about the method and the way of giving the pupils feedback. What is suitable for the teacher and what for the content? For the feedback you have to ask yourself, what do I see when the pupils play different roles and what is the outcome for real life situations? Self-reflective learning, problem-based learning, an appreciative, empathetic approach and, above all, communication at eye level is encouraged. Another teacher mentions the VIVID (2021) association in the field of addiction prevention. The association has a very 
good, easy-to-implement concept with very concrete suggestions for expanding the social and emotional competence of the pupils. VIVID provides folders for free with suggestions and ideas, especially for teachers whose experience with social learning is still at the beginning. Although VIVID is an addiction prevention programme, the focus is on strengthening one's own personality. It is about making oneself strong and recognizing one's actual abilities.

In a school this folder is still called "I-folder" in the first year. The folder begins with the "I", then expands to include the "you" and ends with the "togetherness". The folder gives teachers the possibility to create a lesson very quickly.

\subsection{Changes}

In the category of changes, the teachers answer the question: What changes are needed to enable a better implementation of social and emotional learning in school?

All participants say that there is a need for changes, e.g. more breaks or more free space, but this is not possible in the current school system. There should be a concept that strengthens the pupils' personal responsibility and independence within the framework of a coaching lesson. Especially social learning needs more time and space in everyday school life. The curriculum should implement that the teachers should work with real life situations, in which pupils learn how to deal with their emotions and react appropriately. Another problem is the structure of a "50-minute cycle" for one subject. Conflicts are often left half-finished. One teacher sees the need for change in society in general, away from the performance principle towards a society in which social and emotional competences gain in value. One teacher sums it up with the sentence that she can create her own place, but it also needs a place from the system. Social and emotional learning needs to be brought more into the public awareness, the value of this area needs to be increased. To strengthen the self-responsibility of the pupils, student parliament, a social course or a chill base or peer mediation can be implemented. In the peer mediation, peers or high school students come to the classes and help the 
pupils to solve their conflicts. This approach is very popular, because the conflict parties feel better understood by their peers. For three teachers the problem lies in the lack of financial and time resources as well as personal competences of the individual teacher. When you have to solve a complex problem or a concrete situation with binary solution options, it needs more than just teaching the subject matter. It needs other approaches and more practical experience. Furthermore, the headmaster makes a significant contribution to whether teaching of social and emotional learning is promoted or rather hindered. If the teacher has a lot of leeway, he/she is able to move and achieve something. As a result, emotional and social learning should already be taught as part of the university training and be deepened or expanded in further training and not firstly acquired. Teachers should be supported with counselling, supervision, stress management, work-life balance, resilience, which are currently not really included in the basic university curriculum. One teacher demands free, continuous offers of supervision or coaching for teachers. Counselling by colleagues and exchange should be encouraged. A way to counsel the pupils to avoid conflicts are break-out rooms, in which new groups of students can always be put together. This also helps to avoid feelings of exclusion and ensures mutual communication. During attendance hours additional community-focused projects are available. The school of one teacher has chosen the vision: "In the first two weeks of school only social learning happens and - how do I learn?". It focuses on the attitude towards oneself and one's learning. Mostly all teachers agree that the role model effect and a positive attitude is important for the pupils. They imitate the behavior.

Picking up on the COVID situation one teacher adds that the initial technical problems were quickly solved, but the lack of the social component became increasingly obvious. According to this, the technical handling of distance learning functions smoothly for the most part, but the students lack the process of interaction, social learning, human exchange or just being able to vent their frustrations with a fellow student.

In the next chapter the practical tools nonviolent communication and paraphrasing, which were named by the participants of the focus groups are described. Both tools can directly be integrated in classrooms. 


\section{Practical tools}

Nonviolent Communication, developed by Marshall Rosenberg $(2003,2015)$ guides us to reframe how we express ourselves, how we hear others and resolve conflicts by focusing our consciousness on what we are observing, feeling, needing, and requesting. Through these four steps of nonviolent communication, appreciative conversations can be held in order to avoid or resolve conflicts.

The first component of nonviolent communication involves the distinction between observation and evaluation. Through pure observation, you can make your conversation partner more aware of your own situation. If observation and evaluation are mixed up, the other person hears criticism more often and takes a defensive stance. Nonviolent communication does not aim to completely hide evaluations, but to develop an awareness of the separation of these two opposites.

It is useful to imagine how a camera objectively observes a situation from the outside. A camera can also only be used to record observations without giving an assessment. So, an observation is always related to a time frame and a time context (Rosenberg, 2016; Rust, 2011).

Table no. 2. Example for observation and evaluation

\begin{tabular}{|l|l|}
\hline Observation & Evaluation \\
\hline $\begin{array}{l}\text { On Wednesday you went to the cinema } \\
\text { with my girlfriend. }\end{array}$ & $\begin{array}{l}\text { On Wednesday you met with my girlfriend for } \\
\text { quite a long time. }\end{array}$ \\
\hline
\end{tabular}

While in the first phase of nonviolent communication observation is relevant, in the second step special attention must be paid to feelings. In today's society, feelings are often not given special importance and many people also have difficulties in clearly expressing their real feelings. Fear, sadness, but also happiness and joy are often ignored. In this context, Rosenberg (2016, p. 51) emphasizes that the phrase "I feel that" or "I feel as if..." only expresses an opinion, while a feeling itself is not revealed (for example "I 
feel as if I'm living with a wall"). Therefore, the formulation "I am ..." should be used, for example /

I'm exhausted.

I'm happy.

I'm frustrated.

I'm excited (Holler, 2005, p. 64, 74).

Needs are the root of feelings and the elementary conditions for life and survival. Just as feelings often cannot be expressed, needs are also confused with strategies, interpretations and behavioral diagnoses of others. So, conflicts often arise in the family, in everyday school life and everyday work as a result of the inadequate fulfillment of needs.

For expressing needs you can use the following language patterns:

1. I feel ... because I ... need.

E.g.: I feel under pressure because I need rest/relaxation.

2. I am ... because ... is important to me /for me.

E.g.: I am annoyed because it is important to me to use my time wisely.

The expression of needs significantly influences the four steps of nonviolent communication and also affects the others. To resolve a conflict, it is often necessary to ask about one's own needs and those of the other person.

After observation, feelings and needs, the fourth element of non-violent communication is the correct formulation of requests. Requests often contain disguised demands or are formulated vaguely and ambiguously. In order to fulfill a need, requests should be named in such a way that the willingness of the other person to respond considerately increases as well. It should therefore be avoided to express requests in a negative form, rather it is advantageous to use positive language of action. However, conveying a clear and unambiguous request seems difficult, especially since there may be uncertainties about what you actually want yourself. Because of this, a request should contain a specific action, be positively formulated and be verifiable. "Pious wishes" should be avoided and requests that can be fulfilled should be formulated.

Summing up nonviolent communication is not a method to change the behavior 
of other pupils and teachers or to get one's own way. This mediative technique is suitable for building relationships that include sensitive, appreciative and considerate behavior.

Another tool which teachers can integrate to avoid conflicts in classrooms but can also be used in counselling situations is paraphrasing. It is important that not only the teacher paraphrases. He/she should also tell the students the background of this tool so that also the pupils are able to use it. While paraphrasing can be explained very simple, it is harder to paraphrase in (high) escalated situations.

In the sense of nonviolent communication, paraphrasing is also done by reproducing what is heard in one's own words, with the difference of formulating the content as a question. This signals understanding to the interlocutor and, if necessary, provides the opportunity for correction. The aim of the question is to empathize with the other person and at the same time to support him or her in revising what has been misunderstood. Paraphrasing is useful in situations where there is uncertainty about whether you have understood what you have heard correctly or when the other person needs confirmation (Rosenberg, 2016).

This kind of summary helps to sort topics and arguments as well as to check if everything relevant has been named (Lindemann et al., 2018). It gives the speaker the opportunity to reconsider his/her statement. If the statement was understood correctly, the paraphrase is confirmed. Otherwise he/she has the opportunity to correct it (Rosenberg, 2016).

It is therefore a question of the interlocutor reproducing what he or she has heard in his or her own words. Thus, the understanding can be checked and corrected if necessary to prevent misunderstandings. Paraphrasing shows that what was said by the person speaking was both heard and the essence of his statement was grasped by the interlocutor and there is a willingness to continue talking about the topic that has been started. Paraphrasing signals interest and appreciation.

Example 1:

„I feel quite disregarded.” 
„It sounds like you are dissatisfied and disappointed because it's about appreciation." (Holler, 2017, p. 338).

Example 2:

„I don't know how we're going to do this if nobody has the overview and results aren't being matched."

„You are concerned with transparency and exchange. Does that apply?" (Geier, 2017, p. 322).

\section{Discussion}

Regarding the practical application of social emotional learning in schools, it belongs to the interest of the school management and the agreed school mission statement, if teachers use social emotional learning in the classrooms. The headmaster can support the teachers by allowing them to attend additional workshops to develop their competences. Most of the participants of the focus groups report that social emotional learning is integrated selectively into daily school life with one or two lessons per week. Usually, these units take place in the first and second year of secondary education. There are nine years of compulsory education in Austria. For the first four years, pupils must attend primary schools. After graduation, children from the age of 10 choose between different types of secondary school. Then, all pupils must either go into professional training or continue school education, until the age of 18 .

At the beginning of secondary education, some teachers use the first one or two weeks for social emotional learning or an excursion in which the class climate is strengthened and the pupils, who attended different schools, get to know each other.

The teachers mention several topics, which are discussed in social emotional learning classes, for example conflicts in the school class, teamwork, bullying, accepting diversity, personality development and getting to know their own strengths and weaknesses. Pedagogical advisors, school mediators and teachers educate buddies, but in the most cases the individual class teachers have to implement social emotional learning. The most important problem is 
that there is not enough time for this type of learning in the individual subjects.

The participants agree that they gathered a pool of methodologies and tools over the last years. The teachers took part in further education and workshops, gathered materials, and make it available to their colleagues. These materials are literature, handbooks, guidelines ready-made lessons or best practices.

All focus group participants prefer certain methods and tools and use them more often because they feel comfortable using the techniques. Some of the tools are role playing games, theatre methodologies, group work, taking positions in the room, emotion cards, cooperation games or peer mediation.

The teachers suggest including obligatory social emotional learning courses for future teachers at the university level. Moreover, pre-service teachers should have a lot of practical training to gain more experience in the classroom during studying at the university. For all teachers free counselling, coaching and supervision should be available. Some teachers are of the opinion that social emotional learning should be anchored in school development policies. Furthermore, the local authorities for education should regulate it. With a whole-school approach not only committed teachers are able to implement this form of learning. Some teachers mention that changes are sometimes dreams, which can't be realized, because first the school management has to integrate social emotional learning in the professional curriculum.

The results show that young teachers are often unprepared to deal with stress in conflict situations but have lots of professional competences. Therefore, counselling competence is especially important in situations where social emotional learning (e.g., teaching conflict management competences) is required. This has on the one hand a positive impact on the individual child, and on the other hand on the general atmosphere in the classroom. More time and more space for dealing with conflicts and other daily challenges, such as strengthening the classroom climate, should be deeply embedded in the school culture. In addition, networking opportunities between teachers, including those from different school systems, should be considered to share practical experiences and provide space for personal exchange (WUS Austria, 2021). 


\section{References}

- CASEL (Collaborative for Academic, Social, and Emotional Learning). (2021, September 6). What Is the CASEL Framework? https://casel.org/sel-framework/

- Center for Social Competence. (2021, September 6). https://soziale-kompetenz.uni-graz.at/de/

- Cyr, J. (2019). Focus Groups for the Social Science Researcher. Cambridge University Press.

- EV South-East. (2021, September 6). https://www.lehramt-so.at/ev-sued-ost/

- Danner, M.J.E., Worth Pickering, J., \& Paredes, T.M. (2018). Using focus groups to listen, learn, and lead in higher education. Stylus Publishing, LLC.

- Drechsel, B., Sauer, D., Paetsch, J., Fricke, J., \& Wolstein, J. (2020). Beratungskompetenzen von Lehramtsstudierenden im erziehungswissenschaftlichen Studium evidenzbasiert fördern - Das Bamberger PeerBeratungstraining. Sonderheft Evidenzbasierung in der Lehrkräftebildung, EZFE, 4, 193-214.

- Gartmeier, M. (2019). Elternberatung als Herausforderung: Eine Perspektivenübernahme. Pädagogische Führung. Zeitschrift für Schulleitung und Schulberatung, 6, 212-213.

- Geier, F. (2017). Kommunikation in der Mediation. In Th. Trenczek, D. Berning, C. Lenz \& H.-D. Will (Eds.), Handbuch Mediation und Konfliktmanagement (2nd ed., pp. 316-322). Nomos.

- Grewe, N. (2015). Gesprächsführung und Leitlinien der Beratung. In N. Grewe (Ed.), Praxishandbuch Beratung in der Schule: Grundlagen, Methoden und Fallbeispiele (3rd ed.). Link.

- Heyse, V., \& Erpenbeck, J. (2009). Kompetenztraining: Informations- und Trainingsprogramme (2nd ed.). Schäffer-Poeschel.

- Holler, I. (2005). Trainingsbuch Gewaltfreie Kommunikation. Junfermann Verlag.

- Holler, I. (2017). Gewaltfreie Kommunikation in der Mediation. In Th. Trenczek, D. Berning, C. Lenz \& H.-D. Will (Eds.), Handbuch Mediation und Konfliktmanagement (2nd ed., pp. 335-339). Nomos.

- Krueger, R.A., \& Casey, M.A. (2009). Focus groups: A practical guide for applied research (4th ed.). Sage.

- Lindemann, H., Mayer, C.-H., \& Osterfeld, I. (2018). Systemisch-lösungsorientierte Mediation und Konfliktklärung. Vandenhoeck \& Ruprecht GmbH \& Co. KG.

- Mayring, Ph. (2015). Qualitative Inhaltsanalyse: Grundlagen und Techniken (12th ed.). Beltz.

- Palzkill, B., Müller, G., \& Schute, E. (2015). Erfolgreiche Gesprächsführung in der Schule: Grenzen ziehen, Konflikte lösen, beraten. Cornelsen.

- Rosenberg, M. (2003). Life-Enriching Education: Nonviolent Communication 
helps schools improve performance, reduce conflict, and enhance relationships. PuddleDancer Press.

- Rosenberg, M. (2015). Nonviolent Communication: A Language of Life (3rd ed.). PuddleDancer Press.

- Rosenberg, M. (2016). Gewaltfreie Kommunikation. Eine Sprache des Lebens (12th ed.). Junfermann Verlag.

- Rust, S. (2011). Wenn die Giraffe mit dem Wolf tanzt. Vier Schritte zu einer einfühlsamen Kommunikation (8th ed.). KOHA-Verlag.

- Schnebel, S. (2017). Professionell beraten: Beratungskompetenz in der Schule (3rd ed.). Beltz.

- Schulz, M., Mack, B., \& Renn, O. (Eds.). (2012). Fokusgruppen in der Empirischen Sozialwissenschaft: Von der Konzeption bis zur Auswertung. VS Verlag für Sozialwissenschaften.

- Sonnleitner, K., \& Gschweitl, V. (2021, September 6). Conflict Diagnosis: How to deal with a conflict?

http://skills.turiba.lv/files/ARTICLE\%20Conflict\%20Diagnosis.pdf

- Vaughn, Sh., Schumm, J., \& Sinagub, J. (1996). Focus Group Interviews in Education and Psychology. Sage Publications.

- VIVID. (2021, September 6). https://www.vivid.at/

- WUS Austria. (2021, September 6). Austrian National Report on social and emotional learning. http://www.wus-austria.org/files/user/docs/Projects/ SEEVAL/Report_Focus-groups_Round-tables_Austria_FINAL.pdf

- WUS Austria. (2021, September 6). https://www.wus-austria.org/

The online version of this article can be found at: http://revped.ise.ro/category/2021-en/

\section{(Cc) BY-NC-BA}

This work is licensed under the Creative Commons Attribution-NonCommercial-ShareAlike 4.0 International License.

To view a copy of this license, visit http://creativecommons.org/licenses/by-nc-sa/4.0/ or send a letter to Creative Commons, PO Box 1866, Mountain View, CA 94042, USA.
Versiunea online a acestui articol poate fi găsită la: http://revped.ise.ro/category/2021-ro/

\section{(cc) $\mathrm{Br}-\mathrm{NC}-\mathrm{sa}$}

Această lucrare este licen iată sub Creative Commons Attribution-NonCommercial-ShareAlike 4.0 International License.

Pentru a vedea o copie a acestei licen e, vizita $i$ http://creativecommons.org/licenses/by-nc-sa/4.0/ sau trimite i o scrisoare către Creative Commons, PO Box 1866, Mountain View, CA 94042, SUA. 



\title{
AUTOEFICACITATEA ŞI BURNOUT-UL ÎN RÂNDUL PROFESORILOR, ÎN PERIOADA ŞCOLII ONLINE
}

\author{
Adela Mihaela ăranu* \\ Universitatea Tehnică de Construc ii Bucureşti, \\ Departamentul pentru Pregătirea Personalului Didactic, \\ Bucureşti, România \\ adela.taranu@ise.ro
}

Ileana Vătăşescu**

Cabinet Individual de Psihologie,

Craiova, România

iulia_cib@yahoo.com

Bianca Vătăşescu***

Cabinet Individual de Psihologie,

Craiova, România

vatasescu.bianca@gmail.com

\section{Rezumat}

În timpul pandemiei de COVID-19, trecerea la învă ământul online a schimbat substan ial caracteristicile activită ilor profesorilor, în special datorită folosirii intensive a telecomunica iilor. O serie de studii recente explorează deja efectele produse de aceste schimbări de cadru asupra comportamentului individual şi atrag aten ia asupra riscurilor în zona sănătă ii mintale pentru cei implica i. Date anterioare indică faptul că nivelul de burnout resim it de profesori este mai puternic decât cel al persoanelor cu alte profesii (Shoji et al., 2016), însă studiile care explorează stresul şi burnout-ul asociate cu munca online sunt incipiente.

Studiul de fa ă analizează rela ia dintre burnout şi autoeficacitate pentru un lot de 50 de

* Conferen iar universitar doctor, Departamentul pentru Pregătirea Personalului

Didactic, Universitatea Tehnică de Construc ii Bucureşti, Bucureşti, România.

Cercetător ştiin ific gr. II - Centrul Na ional pentru Politici şi Evaluare în

Educa ie - Unitatea de Cercetare în Educa ie, București, România.

** Psihoterapeut, Cabinet Individual de Psihologie, Craiova, România.

*** Psiholog clinician, Cabinet Individual de Psihologie, Craiova, România. 
profesori dintr-o şcoală în care s-a trecut la predarea online. Necesitatea cercetării acestei asocieri pleacă de la premisa că eficacitatea autopercepută este importantă în mobilizarea profesorului pentru schimbările aşteptate în perioada predării online. Diferite studii indică o corela ie inversă între autoeficacitate şi burnout (Friedman, 2003), respectiv între autoeficacitatea profesorului şi două fa ete ale burnout-ului: epuizare emo ională şi depersonalizare (Skaalvik \& Skaalvik, 2010). Ne-am propus explorarea asocierii de moment între variabilele dependente măsurate şi estimarea factorilor care au avut impact negativ asupra autoeficacită ii percepute a profesorilor în perioada lucrului în online. Chiar dacă datele surprinse nu se pot generaliza şi nu se poate vorbi despre o rela ie cauză-efect, studiul de fa ă surprinde un moment real care poate fundamenta o interven ie de ameliorare/ optimizare, cel pu in la nivelul şcolii de referin ă.

Cuvinte-cheie: autoeficacitate, burnout-ul profesorilor, pandemia de COVID-19, predare online.

\section{Abstract}

During the COVID-19 pandemic, the transition to the online education substantially changed the characteristics of the teachers' activities, especially due to the intensive use of telecommunications. A number of recent studies are already exploring the effects of these framework changes on individual behavior and drawing attention to the risks of mental health for those involved. Previous data indicate that the level of burnout experienced between the teachers is much stronger compared to the symptoms felt by other professionals (Shoji et al., 2016), but studies exploring the stress and burnout associated with working online are incipient.

The present study analyzes the relationship between burnout and self-efficacy for a group of 50 teachers from a secondary school during online teaching. The need to research this correlation starts from the premise that self-perceived effectiveness is important in mobilizing the teachers for the expected changes during online teaching. Previous data indicate an inverse correlation between self-efficacy and burnout (Friedman, 2003), respectively between teachers self-efficacy and two facets of the burnout: emotional exhaustion and depersonalization (Skaalvik \& Skaalvik, 2010). Our aim is to explore the momentary correlation between the dependent variables and to estimate the factors that had a negative impact on the perceived self-efficacy of teachers during online work. Even if the captured data cannot be generalized and we cannot talk about a cause-effect relation, the present study captures a real moment that can substantiate an improvement/optimization of the intervention, at least at the level of the reference/referential school.

Keywords: COVID-19 pandemic, online teaching, teacher burnout, teacher selfefficacy. 


\section{Introducere}

În contextul măsurilor de distan are socială, educa ia s-a aflat în fa a unei provocări care a putut fi gestionată cu precădere cu suport digital. Pandemia de COVID-19 a avut un impact major asupra telecomunica iilor, iar studiile confirmă faptul că a crescut exponen ial utilizarea aplica iilor media care permit teleconferin ele, învă area online şi comunicarea socială pe re elele de socializare (Mheidly et al., 2020). Schimbarea rutinelor individuale şi institu ionale au adus provocări legate de starea de bine a personalului din învă ământ, a cursan ilor şi a părin ilor şi a afectat capacitatea şcolilor de a răspunde la aceste provocări şi de a oferi sprijin pentru elevi şi personal.

Potrivit OMS (2020), gestionarea stresului şi anxietă ii devine principala problemă de sănătate mintală generată de pandemia de COVID-19. Date de cercetare arată că persoanele care au petrecut mai mult de 10 zile în carantină/ lockdown erau mai predispuse să raporteze simptome de stres posttraumatic, confuzie şi furie, fa ă de perioada anterioară (Brooks et al., 2020). Se estimează că în perioada lockdown-ului din 2020, pe lângă factorii de stres genera i de izolarea în case, factorii asocia i cu telecomunica iile au accelerat inciden a burnout-ului (Mheidly et al., 2020). De asemenea, datele anterioare arată că nivelul de eficacitate al elevilor a fost scăzut în clasele unde profesorii au ob inut scoruri ridicate la nivelul de stres şi burnout şi redus la strategii de coping (Herman et al., 2018).

Studiul ETUCE (2021) privind aspecte ocupa ionale ale personalului din sistemele de învă ământ din 40 de tări europene, inclusiv România, avertizează alături de UNESCO asupra faptului că profesorii au experimentat niveluri mai mari de distres din cauza volumului de muncă în timpul şcolii la distan ă. Între nevoile profesorilor raportate de responden ii la studiu, suportul psihologic se află pe locul trei (după asigurarea unui mediu sigur şi sănătos de muncă şi sprijin financiar pentru tehnologie).

Referitor la con inutul muncii, responden ii profesori în cele mai ample studii din România în perioada şcolii la distan ă indică provocări, chiar obstacole în eficien a activită ii referitoare la accesul la echipamente şi internet de calitate necesare pentru desfăşurarea activită ilor online cu elevii, resurse de timp ample solicitate de pregătirea şi organizarea activită ilor online, insuficienta 
dezvoltare a competen elor digitale necesare pentru utilizarea diferitelor instrumente şi aplica ii online, disconfort profesional în interac iunea cu elevii în contexte online (Botnariuc et al., 2020; UCE-CNPEE, 2020). În acelaşi timp se consemnează în procente situate în jurul valorii de $40 \%$ stări precum confuzie, nerăbdare, teamă, furie, triste e, îngrijorare, nemul umire şi nervozitate resim ite în mare şi foarte mare măsură de profesori (ISMBCMBRAE, 2020).

\subsection{Burnout-ul în rândul profesorilor}

Burnout-ul este cunoscut sub numele de sindrom de epuizare cronică şi atitudine negativă fa ă de muncă, cu o etiologie legată de gestionarea defectuoasă a stresului în muncă. În timp, acest concept a primit mai multe defini ii şi diferite dimensiuni de bază, dar trei sunt cele mai răspândite astăzi - epuizare, cinism/ depersonalizare şi nivel scăzut de realizare personală/ ineficien ă (Bakker \& Sanz-Vergel, 2020). Epuizarea este descrisă ca un sentiment de pierdere a energiei, din cauza expunerii continue la condi ii de muncă extrem de solicitante; este simbolică şi cel mai strâns asociată cu performan a în rol, dar şi cu alte rezultate organiza ionale cum sunt absenteismul şi performan a autoraportată la locul de muncă (Schaufeli \& Buunk, 2003). Cinismul/ depersonalizarea este o stare de detaşare ostilă de munca proprie, înso ită de iritabilitate, atitudini inadecvate şi retragere; apare ca urmare a epuizării emo ionale şi este ini ial un mecanism defensiv, care ac ionează ca un tampon emo ional sub forma unei preocupări detaşate cu poten ial de transformare în dezumanizare (Maslach \& Leiter, 2016). Sentimentul de nerealizare este adesea asociat cu o productivitate scăzută şi incapacitatea de a face fa ă solicitărilor. Oamenii tind să-şi piardă progresiv credin a în capacitatea lor de a face la ceea ce li se cere, ceea ce poate duce la un verdict autoimpus de eşec (Maslach \& Leiter, 2016). Se estimează că experien a epuizării tinde să reducă încrederea pe care o au lucrătorii în îndeplinirea cu succes a sarcinilor lor (Bakker et al., 2003), conducând la o scădere a performan ei lor. În acelaşi timp, cinismul şi ineficien a din cadrul burnout-ului tind să afişeze modele mai pu in consistente în cadrul studiilor care măsoară performan a în muncă (Taris, 2006).

Metaanalizele care au lucrat cu datele ob inute în rândul cadrelor didactice 
au surprins un burnout mai puternic decât studiile efectuate în rândul lucrătorilor cu alte ocupa ii (Shoji et al., 2016).

În urma studiului în care Farber a estimat că aproximativ $20 \%$ dintre profesorii americani se confruntă cu burnout (1983), în baza experien ei psihoterapeutice acesta reconsideră abordarea conceptului ca sindrom cu etiologie şi simptome relativ consistente în cazul tuturor indivizilor şi propune trei profiluri de burnout (Farber, 2000): (1) burnout tip epuizare/ uzură, caz în care o persoană se dezangajează de muncă, sim indu-se depăşit în confruntarea cu stresul; (2) burnout clasic/frenetic, caz în care o persoană lucrează din ce în ce mai mult atunci când se confruntă cu factorii stresori, uneori riscându-şi sănătatea şi ignorându-şi via a personală; (3) tipul demotivat, în cazul persoanelor care se confruntă sau percep condi iile de muncă monotone şi nestimulative; pentru această categorie stresul muncii nu este deosebit de mare, dar recompensele nu sunt intrinseci şi în cele din urmă îşi pierd implicarea şi creativitatea profesională.

Potrivit lui Farber (2000), profilul profesorului predispus la burnout este: vârstă sub 40 de ani, predă în ciclul gimnazial sau liceal, idealişti sau pasiona i de munca lor, tind să fie influen a i de evenimente externe/ situa ii care scapă controlului mai degrabă decât de reac ii interne. Factorii de stres cel mai des experimenta i de către profesori sunt: muncă excesivă, clase numeroase şi elevi apatici şi/sau perturbatori. Tipul de şcoală care generează un mediu de lucru ce favorizează burnout-ul: şcoli urbane de mari dimensiuni, săli de clasă supraaglomerate, deteriorate sau murdare, personal şi echipamente insuficiente, management care nu oferă sprijin interpersonal sau administrativ pentru eforturile profesorilor. În cele din urmă, subevaluarea cronică a muncii profesorilor şi, în mod similar, continuarea denigrării muncii îndeplinite în primul rând de femei constituie un context social care îi fac pe profesori să se simtă neaprecia i şi să muncească sub presiunea de a ob ine rezultate educa ionale „mai bune” (Farber, 2000).

De-a lungul timpului au fost testate numeroase programe de interven ie pentru diminuarea burnout-ului în rândul profesorilor, cele mai comune componente ale acestor programe incluzând practicile de tip mindfulness, tehnicile de relaxare, cele de identificare şi corectare a gândurilor disfunc ionale/ negative şi sprijinul colegial (Ansley et al., 2021). Date recente de cercetare arată că aceste abordări sunt eficiente pentru epuizarea emo ională şi nerealizarea 
personală, însă eficacitatea acestor interven ii este aproape nulă în ceea ce priveşte depersonalizarea (Iancu et al., 2018).

\subsection{Autoeficacitatea profesorilor}

Constructul de autoeficacitate indică percep ia asupra propriei capacită ii de a îndeplini sarcini zilnice previzibile care, pe termen lung, modelează procesul de luare a deciziilor. Conceptul de autoeficacitate se bazează în principal pe două teorii psihologice influente ale secolului al XX-lea: locul controlului şi teoria social-cognitivă. În ceea ce priveşte locul controlului, autoeficacitatea profesorului este descrisă ca fiind convingerea lor că performan a elevilor poate fi modelată de profesor, dincolo de influen ele mediului de acasă (Vieluf et al., 2013). Bandura (2019) subliniază că percep ia privind eficacitatea personală determină modul în care persoana percepe oportunită ile şi obstacolele din mediu şi afectează alegerea ac iunilor, efortul şi timpul pe care aceştia sunt dispuşi să le investească când se confruntă cu dificultă i. Persoanele eficiente au mai multe şanse să-şi stabilească obiective mai provocatoare, tind să fie mai rezistente şi să experimenteze mai pu ine emo ii negative în procesul de atingere a acestor obiective (Bandura, 2019). Mai mult, autoeficacitatea corelează negativ cu epuizarea, sugerând că persoanele cu autoeficacitate generală scăzută au o stimă de sine scăzută şi cogni ii negative cu privire la realizările lor (Yao et al., 2018).

Autoeficacitatea profesorului (teacher self-efficacy) a fost descrisă ca un indicator subiectiv al măsurării modului în care profesorii pot realiza sarcini specifice în profesia didactică şi a fost unul dintre cele mai studiate constructe în formarea profesorilor (Morris et al., 2017). Ea este strâns legată nu numai de nivelul stării de bine în activitatea profesională, ci şi de rezultatele şcolare ale elevilor (Vieluf et al., 2013). Studii recente eviden iază faptul că profesorii cu un nivel raportat de autoeficitate ridicat sunt disponibili pentru o rela ie profesională autentică cu elevii şi experimentează mai multă satisfac ie profesională (Granziera \& Perera, 2019). De asemenea, fac apel la creativitate în sarcinile de predare pentru a-i determina pe elevi să în eleagă subiectele complexe sau dificile (Zee \& Koomen, 2016) şi sunt motiva i să diversifice strategiile prin utilizarea resurselor educa ionale digitale de învă are (Glackin \& Hohenstein, 2018). 
Potrivit studiilor recente, aceste asocieri dintre predarea la clasă şi autoeficacitate nu pot fi transferate în cazul predării online. Din raportările profesorilor, autoeficacitatea este percepută ca fiind mai redusă în contextul predării online comparativ cu predarea în mediul fizic (Johnson et al., 2020), mai ales în cazul profesorilor fără experien ă de predare online şi pentru cazurile în care grupurile de elevi au fost la fel de numeroase ca în cadrul fizic (Kenrick, 2020).

Un studiu recent care a măsurat autoeficacitatea în contextul predării online în diferite momente ale pandemiei de COVID-19 pentru 351 de profesori din China a concluzionat că autoeficacitatea în raport cu utilizarea tehnologiei a crescut în timp, odată cu acumularea de experien ă (Ma et al., 2021).

Printre factorii care au condus la scăderea autoeficacită ii asociate predării online, studiile consemnează dificultă ile anticipate cu utilizarea tehnologiei, diminuarea conexiunii socio-emo ionale cu elevii, dificultă ile de lucru cu elevii care prezintă un interes scăzut pentru disciplinele şcolare, cunoaşterea insuficientă a aspectelor pedagogice ale predării online şi caracteristicile consumatoare de timp ale predării online (Bao, 2020; Johnson et al., 2020; Ma et al., 2021; Putri et al., 2020; Scull et al., 2020).

Cercetările efectuate cu privire la stres arată că autoeficacitatea poate func iona ca o resursă - factor individual de autoreglare, ce poate fi activată pentru a minimiza efectele presiunii resim ite şi determină recuperarea după stresul resim it la locul de muncă (Shoji et al., 2016).

O serie de studii au investigat corela ia dintre burnout şi autoeficacitatea profesorului. Zee şi Koomen (2016) au analizat studii publicate între 1976 şi 2014 şi au observat faptul că asocierea dintre burnout şi autoeficacitatea variază de la -0,17 la -0,63 (mediana de -0,25). Mai mult, corela ia între autoeficacitatea profesorilor şi cele trei dimensiuni ale burnout-ului profesorului arată o corela ie între autoeficacitate şi epuizare ce variază de la -0,09 la -0,76 (mediană - 0,25), corela ie între autoeficacitate şi realizare personală ce variază de la 0,13 la 0,75 (mediană 0,36 ) şi corela ie între autoeficacitate şi depersonalizare ce variază de la -0,16 la -0,6 (mediană 0,33). O altă metaanaliză ce include 29 de studii înregistrează o corela ie medie de -0,33 între burnout şi autoeficacitate în rândul profesorilor (Shoji et al., 2016). 
$\mathrm{Cu}$ toate acestea, nu s-a găsit nicio corela ie semnificativă între nivelul autoeficacită ii profesorilor în online şi burnout (Ma et al., 2021). Acest lucru ar putea fi asociat cu faptul că profesorii devin mai pu in energici din cauza multitudinilor sarcinilor zilnice de predare, dar îşi men in autoeficacitatea ridicată raportându-se la realizările lor în predare într-un context diferit/ provocator (Dicke et al., 2018).

\section{Metodologia cercetării}

Studiile sus in existen a unui nivel crescut de burnout în rândul profesorilor. În contextul izolării, al incertitudinii specifice perioadei pandemiei de Covid-19, al schimbării practicilor de predare şi al utilizării intensive a suportului digital în educa ie, anticipăm un nivel scăzut de autoeficacitate şi un nivel crescut al burnout-ului profesorilor.

Metodologia de cercetare porneşte de la concluziile datelor anterioare, potrivit cărora autoeficacitatea este invers corelată cu burnout-ul raportat (Friedman, 2003), respectiv cu două fa ete ale burnout-ului: epuizare emo ională şi depersonalizare (Skaalvik \& Skaalvik, 2010).

De asemenea, s-a luat în considerare următorul aspect: chiar dacă un individ este autoeficace la anumite sarcini, nu înseamnă că este la fel de capabil în toate celelalte sarcini (Bandura, 2019). Am avut în vedere faptul că, în contextul pandemiei generate de Covid-19, autoeficacitatea profesorilor cu privire la modul de a-şi realiza sarcinile a fost un construct în continuă modificare, pe fondul noilor abilitări necesare, cu precădere în zona digitalizării; de aceea, studiul de fa ă s-a raportat la activitatea profesorilor după aproximativ şase luni de la debutul activită ii didactice online.

\subsection{Obiective}

Acest studiu investighează asocierea dintre autoeficacitatea percepută şi burnout-ul în rândul profesorilor dintr-o şcoală gimnazială, raportate la ultimele şase luni de activitate didactică online. Ne-am propus explorarea asocierii de moment între variabilele măsurate şi estimarea factorilor individuali şi 
contextuali care au avut impact negativ asupra autoeficacită ii percepute a profesorilor în perioada predării online.

\subsection{Participan i şi procedură}

Popula ia investigată a fost formată din profesori califica i care predau la ciclul primar şi gimnazial într-o şcoală din mediul urban. Criteriile de includere în lot au vizat vârsta între 22 şi 55 de ani şi experien ă minimă de 3 ani în învă ământ, pentru a nu aduce factori suplimentari cu poten ial în afectarea nivelului de autoeficacitate percepută (poten ial deficit ridicat în zona competen elor didactice sau digitale). A rezultat un lot de 50 profesori, relativ omogen la criteriul gen, $60 \%$ dintre aceştia cu o experien ă de predare în învă ământul preuniversitar între 10 şi 20 de ani şi vârsta între 30 şi 45 de ani, $100 \%$ fără experien a predării online (din rol de profesor/ instructor sau de cursant). Participarea persoanelor la studiu a fost voluntară şi în baza consim ământului informat al responden ilor în toate etapele.

Colectarea datelor s-a realizat online în perioada ianuarie-martie 2021, prin autoraportare în prima etapă şi interviuri individuale online în a doua etapă a studiului. Participan ilor li s-a comunicat necesitatea raportării într-un spa iu privat, lipsit de zgomote şi fără întreruperi, în două serii de aproximativ 15 minute pentru fiecare chestionar şi o serie de 60 minute (pentru interviu).

Studiul de fa ă nu are preten ii de generalizare a datelor surprinse şi nici de interpretări a acestora în termeni de cauză-efect, limitele principale fiind date de caracteristicile lotului de participan i redus numeric, relativ omogen structural şi fără varia ie în privin a institu iei/ mediului de provenien ă. Procedura utilizată surprinde însă un moment real cu caracteristici de noutate la nivel personal şi organiza ional, care poate fundamenta o interven ie de ameliorare/ optimizare, cel pu in la nivelul şcolii de referin ă.

\subsection{Metoda şi instrumentele utilizate}

Au fost colectate date cantitative cu două instrumente pentru măsurarea autoeficacită ii şi a burnout-ului, respectiv Scala de Auto-Eficacitate Independen ă [In] şi Inventarul Maslach de Măsurare a Burnout-ului. Date 
calitative referitoare la factorii asocia i autoeficacită ii au fost colectate prin intermediul interviurilor individuale semistructurate.

Scala de Auto-Eficacitate [In] face parte din Scalele IPIP (International Personality Item Pool) adaptate pe popula ia României, având un indice de fidelitate de .72 şi interval de încredere de .65-.76 (Iliescu et al., 2015). Cuprinde 10 itemi şi scala de scorare este de tip Likert in 5 trepte. Chestionarul a fost completat de întreaga popula ie a lotului (50 persoane).

Inventarul Maslach de măsurare a burnout-ului utilizează trei subscale pentru măsurarea celor trei dimensiuni ale burnout-ului - epuizarea emo ională, depersonalizarea şi sentimentul nerealizării personale; cuprinde 16 itemi, scorare pe scală de rating a frecven ei în 7 trepte (niciodată - zilnic). Pentru a evita sensibilizarea scalei, respoden ii nu au fost informa i referitor la faptul că itemii măsoară nivelul de burnout. Chestionarul a fost completat de întreaga popula ie a lotului (50 persoane).

Interviul individual de profunzime a fost utilizat pentru colectarea datelor calitative referitoare la factorii interni şi externi/ contextuali cu impact negativ asupra autoeficacită ii percepute cu privire la ultimele şase luni în care au predat online. Interviurile au fost organizate pentru şase profesori - trei din aceştia cu scor ridicat la autoeficacitate şi scăzut la burnout, trei cu scor scăzut la autoeficacitate şi crescut la burnout. Am optat pentru un interviu semistructurat condus de moderatori cu experien ă în domeniul psihologiei clinice, datorită tematicii specific clinice (legată de burnout) şi cu miză ridicată din punct de vedere psihologic şi social.

\section{Rezultate}

Pentru stabilirea corela iilor dintre autoeficacitate şi burnout, cu cele trei aspecte componente (respectiv epuizare, cinism/ depersonalizare şi nerealizare/ ineficien ă profesională), s-a calculat coeficientul Pearson. Au fost ob inute corela ii puternice între scale pentru popula ia de 50 de profesori care predau la ciclul primar şi gimnazial într-o şcoală din mediul urban. Se pot vedea în continuare tablourile corela iilor ob inute. 
Graficul nr. 1. Corela ii autoeficacitate - epuizare

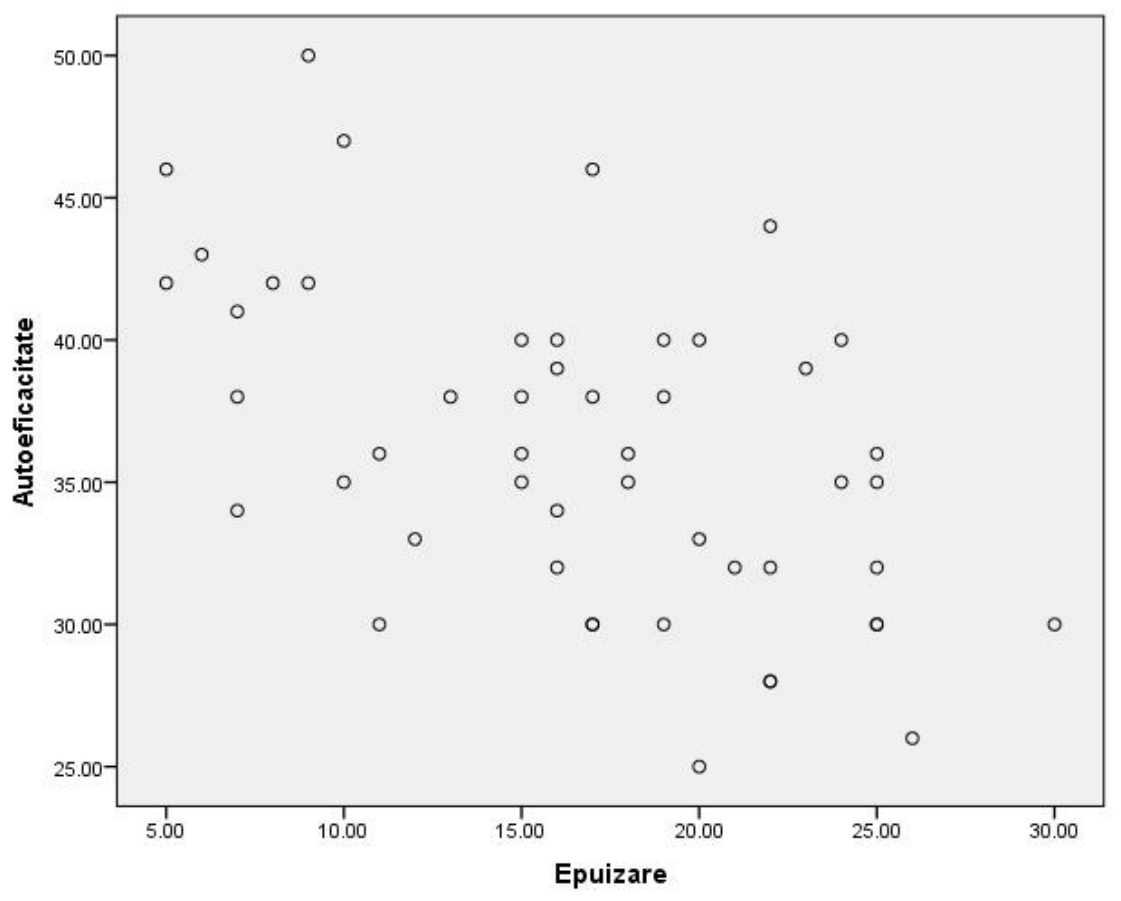

Pentru asocierea dintre autoeficacitate şi epuizare rezultatele studiului arată o corela ie negativă r=-.529 (p<0,005).

În ceea ce priveşte asocierea dintre autoeficacitate şi nerealizare/ ineficien ă profesională, rezultatele studiului arată o corela ie negativă r= -.499 $(p<0,005)$. Se observă ca sentimentul de nerealizare înregistrează cele mai crescute valori dintre cele trei dimensiuni ale burnout-ului. 
Graficul nr. 2. Corela ii autoeficacitate - nerealizarel ineficien ă profesională

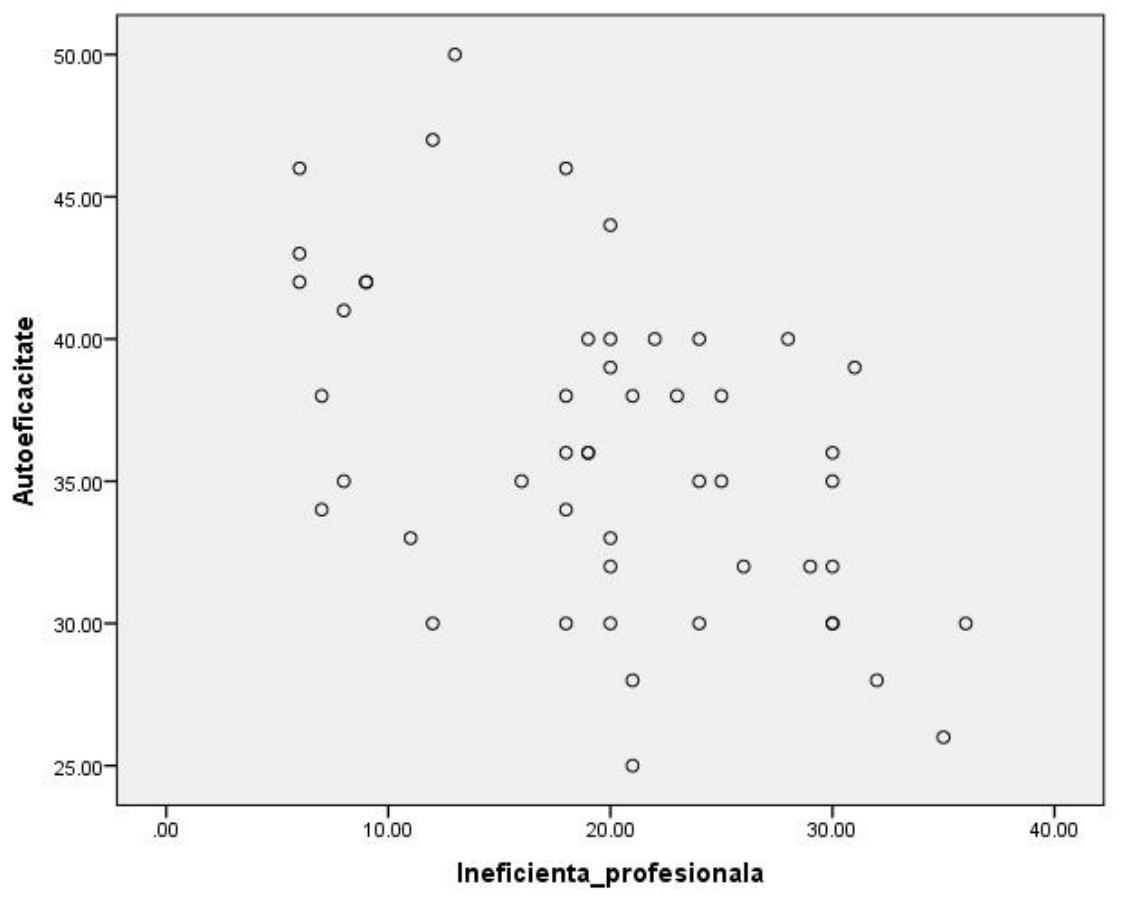

Similar, rezultatele studiului arată o corela ie negativă r=-.481 (p<0,005) pentru asocierea dintre autoeficacitate şi depersonalizare/ cinism. 
Graficul nr. 3. Corela ii autoeficacitate - cinism/ depersonalizare

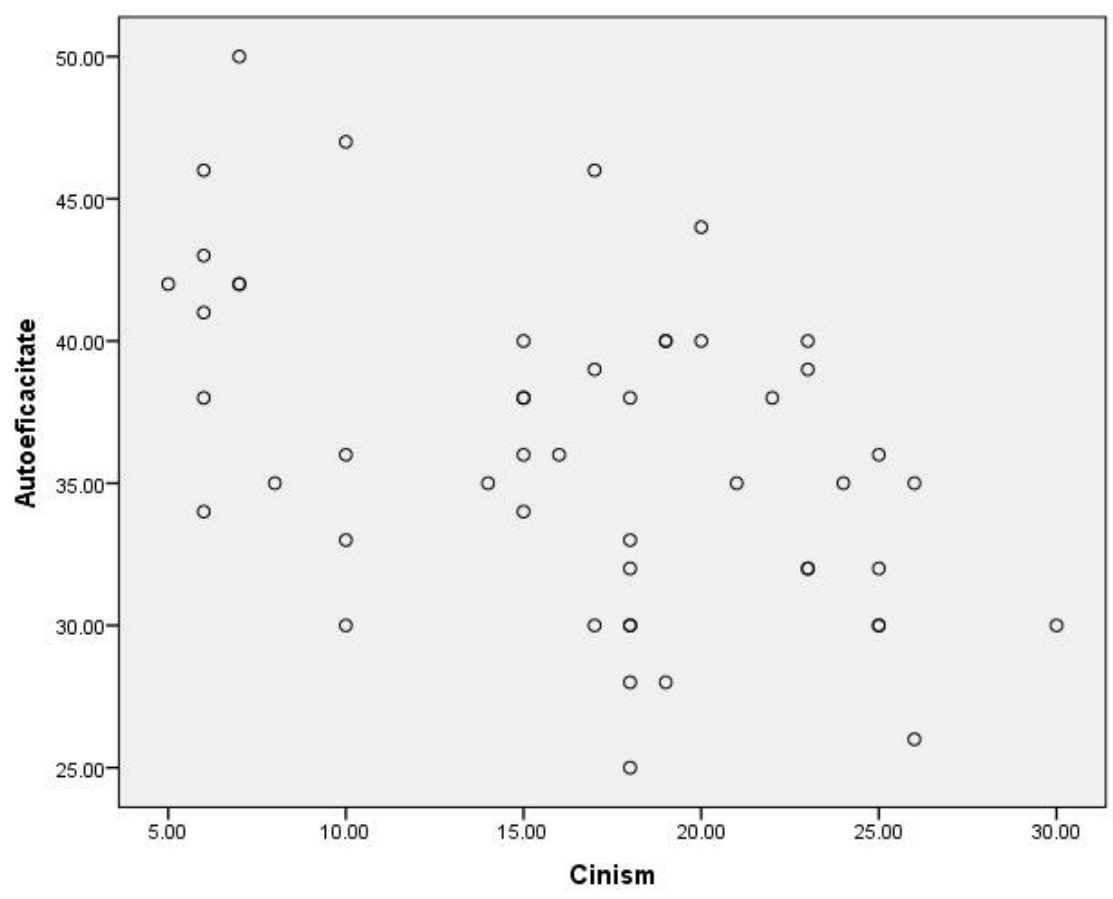

Pentru toate cele trei perechi de aspecte măsurate, rezultatele înregistrează corela ii negative (niveluri ridicate de epuizare, cinism/ depersonalizare şi nerealizare/ ineficien ă profesională se corelează cu un nivel scăzut de autoeficacitate), coeficientul indicând o mărime a efectului semnificativă. $\mathrm{Cu}$ toate acestea, analiza graficelor de tip scatterplot eviden iază că datele ob inute nu sunt suficient de bine grupate pentru a aduce informa ii suplimentare în confirmarea corela iilor puternice ob inute. O posibilă explica ie pentru această dispersie a datelor este lotul restrâns de cercetare şi varietatea caracteristicilor acestora - vârste diferite, cadru diferit de predare (primar/ gimnazial), nivel variabil de experien ă didactică, nivel variat al competen elor digitale. De asemenea, numărul de responden i nu a fost suficient de mare pentru a analiza modul în care autoeficacitatea şi burnoutul sunt modelate în func ie de numărul de elevi la clasă (sub 25 elevi şi peste 25 elevi) sau în func ie de durata de predare online şi numărul orelor de muncă pe zi. 
Ulterior, datele calitative colectate pentru identificarea factorilor individuali şi contextuali care au avut impact negativ asupra autoeficacită ii percepute a profesorilor în perioada predării online au permis creionarea unor profiluri relativ consistente.

Interviurile de profunzime realizate cu trei profesori care au ob inut cele mai scăzute rezultate în ce priveşte autoeficacitatea şi ridicate în privin a burnoutului resim it în ultimele şase luni de predare online au eviden iat următoarele caracteristici ale acestora: predau mai degrabă la gimnaziu, deci lucrează cu număr mare de elevi din clase diferite; profesori nou veni i în şcoală (sub 2 ani) sau slab integra i în comunitatea şcolii; resimt o presiune subiectivă crescută pentru succes profesional; resimt insatisfac ie în privin a recunoaşterii muncii de către elevi şi părin i; au sentimentul că nu au acces complet la informa ii dinspre managementul şcolii sau de la colegi; capacitate redusă de a identifica persoanele resursă sau de sprijin dintre colegi/ părin i/ elevi; nevoie resim ită de a fi în contact permanent cu informa ii din afară, asociată cu insecuritate; confruntarea cu evenimente dificile în plan personal; disconfort în rela ia cu tehnologia; toleran ă scăzută la disfunc iile tehnice întâmpinate; rutină slab instalată în plan personal şi profesional în perioada distan ării fizice determinate de pandemia de Covid-19; absen a încrederii că experien a acumulată în predarea online va putea fi valorificată profesional ulterior.

Interviurile de profunzime realizate cu trei profesori care au ob inut cele mai crescute rezultate în ce priveşte autoeficacitatea şi scăzute în privin a burnoutului resim it în ultimele 6 luni de activitate online au eviden iat următoarele caracteristici ale acestora: predau mai degrabă la ciclul primar, deci lucrează cu o singură clasă de elevi sau îşi cunosc bine majoritatea elevilor din perioada predării fa ă în fa ă; au conexiuni bune în comunitatea şcolii, se simt parte a acesteia; simt că munca lor este recunoscută de colegi şi de o parte dintre părin i; sunt relativ autonomi profesional; au un rol profesional bine conturat, îşi cunosc poten ialul şi limitele; caută şi identifică relativ uşor solu ii la dificultă i pe care le consideră provocări; sunt interesa i de educa ia digitală; au experien ă în lucrul pe proiecte; şi-au stabilit o rutina zilnică minimă pentru nevoi personale; au încredere că experien a acumulată în predarea online le aduce deja beneficii şi că o vor valorifica în viitor. 
Ambele tipuri de profesori au men ionat o serie de factori contextuali mai largi sau situa ionali care au poten at preocupările/ distresul asociat predării online. Între acestea, cele mai frecvent invocate dificultă i au vizat: lipsa de previzibilitate legată de durata activită ii online şi aşteptarea continuă ca aceasta să înceteze; îndrumări, decizii şi aşteptări neclare şi în schimbare venite din sistem pe linie ierarhică; creşterea cerin elor de tip birocratic în termene limită nerealiste; îngrijorări legate de modul de evaluare şi recunoaştere a muncii; practica într-o şcoală competitivă, cu presiune mare generată de părin i pentru performan ă; gestionarea lucrului cu elevi neuroatipici sau cu elevi perturbatori; scăderea timpul alocat vie ii de familie şi a calită ii acestuia; timpul prelungit pe device-uri alocat convorbirilor telefonice, mesageriei scrise şi emailurilor; gestionarea predării în scenariul hibrid (simultan online şi fizic la aceeaşi clasă de elevi).

\section{Concluzii}

Obiectivele prezentului studiu au vizat analiza rolului pe care autoeficacitatea îl are în rela ie cu burnout-ul resim it, în cazul unui lot de profesori care predau în şcoală gimnazială centrală într-un oraş de mari dimensiuni din România şi estimarea factorilor individuali şi contextuali care pot influen a scorurile ob inute.

Rezultatele studiului arată o asociere negativă puternică între autoeficacitate şi toate cele trei dimensiuni ale burnout-ului pe lotul evaluat, iar pe componenta sentiment de nerealizare/ lipsa eficien ei s-au înregistrat valorile cele mai ridicate ale burnout-ului profesorilor. Corela iile mari ob inute în cadrul cercetării de fa ă, raportate la perioada de predare online, sunt similare cu cele ale altor studii: cu cât este mai mic sentimentul de autoeficacitate perceput, cu atât este mai mare nivelul de burnout raportat (Friedman, 2003). In ceea ce priveşte profesorii, studiile care au vizat anterior activitatea fa ă în fa ă au consemnat corela ii puternice în special pentru două fa ete ale burnout-ului - epuizare emo ională şi depersonalizare (Skaalvik \& Skaalvik, 2010). Un studiu care a monitorizat periodic profesori din China în timpul pandemiei de COVID-19 timp de şase luni consemnează creşterea treptată a autoeficacită ii în contextul predării online, iar în ceea ce priveşte burnoutul, epuizarea a fost singurul moderator semnificativ raportat la autoeficacitatea 
profesorilor în predarea online (Ma et al., 2021). Pe de altă parte, Putri şi colab. (2020) au raportat faptul că profesorii nu percep cu încredere predarea online şi nu se consideră suficient de pregăti i pentru acest tip de predare.

Raportat la aceste date şi luând în considerare informa iile oferite de interviurile realizate, rezultatele acestui studiu pot fi atribuite, pe de o parte, aspectelor legate de neîncrederea în învă ământul online, de formarea deficitară a profesorilor în zona competen elor digitale şi a gestionării situa iilor noi/ de criză, iar pe de altă parte, pot fi atribuite aspectelor culturale şi organizatorice de tipul dependen ei profesorilor de decizii ierarhice şi de instabilitate structurală a sistemului educa ional, care generează insecuritate suplimentară celei generate de pandemie.

Deşi corela iile negative dintre autoeficacitate şi bournout, ob inute în cadrul studiului de fa ă, sunt semnificative, datele de cercetare trebuie analizate cu precau ie, având în vedere distribuirea neomogenă pe scatterplot determinată în primul rând de numărul mic de responden i. Diferite studii semnalează că nivelul de autoeficacitate şi nivelul de burnout pot fi influen ate de vârstă, gen, numărul de elevi la clasă, timpul de predare în online pe zi, durată de predare online (număr de luni) pe perioada distan ării fizice impuse de măsurile pentru combaterea pandemiei de Covid-19. Din cauza numărului redus de responden i şi caracterului relativ omogen al grupului, studiul de fa ă nu a putut verifica în ce măsură aceste variabile pot influen a nivelul de autoeficacitate şi burnout. Studiile viitoare pe popula ie mai numeroasă ar putea aduce date importante legate de impactul acestor variabile.

Datele ob inute în urma interviurilor de profunzime au semnalat, asemenea altor studii realizate în perioada pandemiei şi şcolii la distan ă (Botnariuc et al., 2020; ETUCE, 2021; ISMB-CMBRAE, 2020; UCE-CNPEE, 2020), nevoi ale profesorilor de ghidaj şi suport în primul rând de natură psihologică (pentru sine şi pentru a putea sprijini elevii), apoi tehnică şi metodologică/ didactică pentru a putea sus ine un construct puternic de autoeficacitate. Datele calitative arată că profesorii care au parcurs perioada predării online cu costuri şi riscuri mai mici din punct de vedere personal şi profesional au fost cei care au lucrat într-un context rela ional mai stabil şi colaborativ (elevi pe care-i cunoşteau bine, colaborare cu colegii şi părin ii) şi care au manifestat autonomie în plan profesional. Credem că, alături de dezvoltarea competen elor profesionale în 
contextul digitalizării educa iei, programele de dezvoltare personală şi a grupurilor/ echipelor de profesori ar putea răspunde nevoilor şi accentelor psihologice individuale şi organiza ionale semnalate de rezultatele acestor studii.

\section{Referin e}

- Ansley, B.M., Houchins, D.E., Varjas, K., Roach, A., Patterson, D., \& Hendrick, R. (2021). The impact of an online stress intervention on burnout and teacher efficacy. Teaching and Teacher Education, 98. https://doi.org/10.1016/j.tate.2020.103251

- Bakker, A.B., \& Sanz-Vergel, A.I. (2020). Burnout. In B.J. Carducci \& C.S. Nave (Eds.), The Wiley Encyclopedia of Personality and Individual Differences: Clinical, Applied, and Cross-Cultural Research: Vol. IV (1st ed., pp. 411-415). John Wiley \& Sons Ltd.

- Bakker, A.B., Demerouti, E., Taris, T.W., Schaufeli, W.B., \& Schreurs, P.J.G. (2003). A multigroup analysis of the job demands-resources model in four home care organizations. International Journal of Stress Management, 10(1), 16-38. https://doi.org/10.1037/1072-5245.10.1.16

- Bandura, A. (2019). Applying theory for human betterment. Perspectives on Psychological Science, 14(1), 12-15. https://doi.org/10.1177/1745691618815165

- Bao, W. (2020). COVID -19 and online teaching in higher education: A case study of Peking University. Human Behavior and Emerging Technologies, 2(2), 113-115. https://doi.org/10.1002/hbe2.191

- Botnariuc, P., Cucoş, C., Glava, C., Iancu, D., Ilie, M., Istrate, O., Labăr, A.V., Pânişoară, I.O., Ştefănescu, D., \& Velea, S. (2020). Şcoala online. Elemente pentru inovarea educa iei. Editura Universită ii din Bucureşti.

- Brooks, S.K., Webster, R.K., Smith, L.E., Woodland, L., Wessely, S., Greenberg, N., \& Rubin, G.J. (2020). The psychological impact of quarantine and how to reduce it: rapid review of the evidence. Lancet, 395(10227), 912-920. https://doi.org/10.1016/S0140-6736(20)30460-8

- Kenrick, A. (2020). Teacher perceptions of efficacy in the secondary virtual classroom: A phenomenological study. City University of Seattle.

- Dicke, T., Stebner, F., Linninger, C., Kunter, M., \& Leutner, D. (2018). Alongitudinal study of teachers' occupational well-being: Applying the job demands-resources model. Journal of Occupational Health Psychology, 23(2), 262-277. https://doi.org/10.1037/ocp0000070

- ETUCE. (2021). Occupational health and safety of teachers, academics and other education personnel in times of COVID-19. https://www.csee-etuce.org/ en/policy-issues/covid-19/4326-new-study-on-vaccination-of-teachers-by-etuce 
- Farber, B.A. (2000). Treatment strategies for different types of teacher burnout. Journal of Clinical psychology, 56(5), 675-689.

https://doi.org/10.1002/(SICI)1097-4679(200005)56:5<675::AID-JCLP8>3.0.CO;2-D

- Farber, B.A. (Ed.). (1983). Stress and burnout in the human service professions. Pergamon.

- Friedman, I.A. (2003). Self-Efficacy and Burnout in Teaching: The Importance of Interpersonal-Relations Efficacy. Social Psychology of Education, 6, 191-215. https://doi.org/10.1023/A:1024723124467

- Glackin, M., \& Hohenstein, J. (2018). Teachers' self-efficacy: Progressing qualitative analysis. International Journal of Research and Method in Education, 41(3), 271-290. https://doi.org/10.1080/1743727X.2017.1295940

- Granziera, H., \& Perera, H. (2019). Relations among teachers' self-efficacy beliefs, engagement, and work satisfaction: A social cognitive view. Contemporary Educational Psychology, 58, 75-84. https://doi.org/10.1016/j.cedpsych.2019.02.003

- Herman, K.C., Hickmon-Rosa, J.E., \& Reinke, W.M. (2018). Empirically derived profiles of teacher stress, burnout, self-efficacy and coping and associated student outcomes. Journal of Positive Behavior Interventions, 20(2), 90-100. https://doi.org/10.1177/1098300717732066

- Iancu, A.E., Rusu, A., Măroiu, C., Păcurar, R., \& Maricu oiu, L.P. (2018). The effectiveness of interventions aimed at reducing teacher burnout: A metaanalysis. Educational Psychology Review, 30(2), 373-396. https://doi.org/10.1007/s10648-017-9420-8

- Iliescu, D., Popa, M., \& Dimache, R. (2015). Adaptarea românească a Setului Interna ional de Itemi de Personalitate: IPIP-Ro. Psihologia Resurselor Umane, 13(1), 83-112.

- ISMB-CMBRAE. (2020). Studiu privind percep ia elevilor, părin ilor şi a profesorilor asupra activită ilor zilnice în perioada de autoizolare.

http://www.cmbrae.ro/2017/wp-content/uploads/2020/06/Raport_studiu_ ISMB_CMBRAE_context_pandemie_2020-1.pdf

- Johnson, N., Veletsianos, G., \& Seaman, J. (2020). U.S. faculty and administrators' experiences and approaches in the early weeks of the COVID-19 pandemic. Online Learning Journal, 24(2), 6-21. http://dx.doi.org/10.24059/olj.v24i2.2285

- Ma, K., Chutiyami, M., Zhang, Y., \& Nicoll, S. (2021). Online teaching selfefficacy during COVID-19: Changes, its associated factors and moderators. Education and information technologies, 26, 6675-6697. https://doi.org/10.1007/s10639-021-10486-3

- Maslach, C., \& Leiter, M.P. (2016). Understanding the burnout experience: recent research and its implications for psychiatry. World psychiatry, 15(2), 103111. https://doi.org/10.1002/wps.20311 
- Mheidly, N., Fares, M.Y., \& Fares, J. (2020). Coping with stress and burnout associated with telecommunication and online learning. Frontiers in Public Health, 8, 1-7. https://doi.org/10.3389/fpubh.2020.574969

- Morris, D., Usher, E., \& Chen, J. (2017). Reconceptualizing the sources of teaching self-efficacy: A critical review of emerging literature. Educational Psychology Review, 29, 795-833. https://doi.org/10.1007/s10648-016-9378-y

- OMS (2021, August 28). Mental health and psychological resilience during the COVID-19 pandemic. http://www.euro.who.int/en/health-topics/healthemergencies/coronavirus-covid-19/news/news/2020/3/mental-health-andpsychological-resilience-during-the-covid-19-pandemic

- Putri, R.S., Purwanto, A., Pramono, R., Asbari, M., Wijayanti, L.M., \& Hyun, C.C. (2020). Impact of the COVID-19 pandemic on online home learning: An explorative study of primary schools in Indonesia. International Journal of Advanced Science and Technology, 29(5), 4809-4818.

- Schaufeli, W.B., \& Buunk, B.P. (2003). Burnout: An overview of 25 years of research and theorizing. In M.J. Schabracq, J.A.M. Winnubst \& C.L. Cooper (Eds.), The handbook of work and health psychology (pp. 282-424). Wiley Online Library. https://doi.org/10.1002/0470013400.ch19

- Scull, J., Phillips, M., Sharma, U., \& Garnier, K. (2020). Innovations in teacher education at the time of COVID19: An Australian perspective. Journal of Education for Teaching, 46(4), 497-506. https://doi.org/10.1080/02607476.2020.1802701

- Shoji, K., Cieslak, R., Smoktunowicz, E., Rogala, A., Benight, C.C., \& Luszczynska, A. (2016). Associations between job burnout and self-efficacy: A meta-analysis. Anxiety, Stress and Coping, 29(4), 367-386.

https://doi.org/10.1080/10615806.2015.1058369

- Skaalvik, E.M., \& Skaalvik, S. (2010). Teacher self-efficacy and teacher burnout: A study of relations. Teaching and teacher education, 26(4), 1059-1069. https://doi.org/10.1016/j.tate.2009.11.001

- Taris, T.W. (2006). Is there a relationship between burnout and objective performance? A critical review of 16 studies. Work \& Stress, 20(4), 316-334. https://doi.org/10.1080/02678370601065893

- UCE-CNPEE. (2020). Invă area la distan ă. Anchetă cu privire la activită ile educa ionale desfăşurate în România, în perioada suspendării cursurilor scolare fa ă în fa $\breve{a}$.

https://www.ise.ro/wp-content/uploads/2020/08/Invatarea-la-distanta_Raportde-cercetare_august-2020.pdf

- Vieluf, S., Kunter, M., \& Van de Vijver, F.J. (2013). Teacher self-efficacy in crossnational perspective. Teaching and Teacher Education, 35, 92-103.

https://doi.org/10.1016/j.tate.2013.05.006 
- Yao, Y., Zhao, S., Gao, X., An, Z., Wang, S., Li, H., \& Dong, Z. (2018). General selfefficacy modifies the effect of stress on burnout in nurses with different personality types. BMC Health Services Research, 18. https://doi.org/10.1186/s12913-018-3478-y

- Zee, M., \& Koomen, H.M.Y. (2016). Teacher self-efficacy and its effects on classroom processes, student academic adjustment, and teacher well-being: A synthesis of 40 years of research. Review of Educational Research, 86(4), 9811015. https://doi.org/10.3102/0034654315626801

The online version of this article can be found at: http://revped.ise.ro/category/2021-en/

\section{(CC) $B Y-N C-3 A$}

This work is licensed under the Creative Commons Attribution-NonCommercial-ShareAlike 4.0 International License.

To view a copy of this license, visit http://creativecommons.org/licenses/by-nc-sa/4.0/ or send a letter to Creative Commons,

PO Box 1866, Mountain View, CA 94042, USA.
Versiunea online a acestui articol poate fi găsită la: http://revped.ise.ro/category/2021-ro/

\section{(cc) B B-NC-sA}

Această lucrare este licen iată sub Creative Commons Attribution-NonCommercial-ShareAlike 4.0 International License.

Pentru a vedea o copie a acestei licen e, vizita $i$ http://creativecommons.org/licenses/by-nc-sa/4.0/ sau trimite i o scrisoare către Creative Commons, PO Box 1866, Mountain View, CA 94042, SUA. 


\section{PERCEP IA PROFESORILOR DIN ÎNVĂ ĂMÂNTUL PREŞCOLAR PRIVIND ASIGURAREA STĂRII DE BINE A COPIILOR, ÎN CONTEXT PANDEMIC}

Mihaela Gu u*

Şcoala Gimnazială Nr. 24 - Structură: Grădini a cu Program Prelungit Nr. 27, Timişoara, România

mihaela.gutu97@e-uvt.ro

Simona Sava**

Universitatea de Vest din Timişoara, Departamentul de Ştiin e ale Educa iei,

Timişoara, România

lidia.sava@e-uvt.ro

\section{Rezumat}

Starea de bine, un concept des vehiculat, a intrat tot mai mult în aten ia specialiştilor şi a practicienilor, mai ales pe parcursul perioadei pandemice, a cărei anvergură a influen at semnificativ starea de bine a tuturor. Scopul studiului comparativcorela ional a fost investigarea percep iilor şi practicilor profesorilor din învă ământul preşcolar românesc privind rolul lor în asigurarea stării de bine a preşcolarilor în grădini a de copii, în contextul pandemiei de COVID-19. Astfel, pornind de la cadrul teoretic ce delimitează factorii care influen ează starea de bine la această vârstă (Aulia et al., 2020; Kwi-Ok et al., 2020; Sönmez \& Ceylan, 2016), s-au folosit Instrumentul de autoevaluare a stării de bine - IASB (Rodawell, 2019), elaborat de Universitatea din Bucureşti în cadrul proiectului Rodawell şi The Scale of Happiness Strategies for Children Used by Preschool Teachers - HSCPT (Sapsağlam et al., 2019). La chestionarea online au răspuns 149 profesori pentru învă ământ preşcolar,

* Profesor pentru învă ământul preşcolar, Grădini a cu Program Prelungit Nr. 27, Şcoala Gimnazială Nr. 24 din Timişoara, România. Masterat „Management educa ional şi dezvoltare curriculară”.

** Profesor universitar doctor, Departamentul de Ştiin e ale Educa iei, Facultatea de Sociologie şi Psihologie, Universitatea de Vest din Timişoara, Timişoara, România. Autor corespondent. (Chttps://orcid.org/0000-0003-2398-1801 
mai ales din jude ul Timiş. Rezultatele studiului (analizate prin Testul-T pentru două eşantioane independente, ANOVA One-Way, Corela ia Spearman) eviden iază existen a unei asocieri pozitive între percep iile şi practicile educatorilor în asigurarea stării de bine, dar şi existen a unor diferen e semnificative statistic între practicile cadrelor didactice din mediul urban vs. rural, în sensul că, deşi percep asemănător starea de bine a copiilor, profesorii din mediul rural tind să utilizeze mai des strategiile de înveselire. Deopotrivă, percep iile profesorilor diferă în func ie de modalitatea de desfăşurare a activită ii didactice în context pandemic: rolul autoperceput şi practicile dedicate pentru asigurarea bunăstării sunt mai intense în format hibrid şi online, decât în cel tradi ional.

Cuvinte-cheie: învă ământ preşcolar, pandemia de Covid-19, percep ia profesorilor, starea de bine, strategii de înveselire.

\section{Abstract}

Well-being, a concept so often discussed, has increasingly come to the attention of specialists and practitioners, especially during the pandemic period whose magnitude has significantly influenced the well-being of all of us. The purpose of the comparative-correlational study was to investigate the perceptions and practices of teachers in Romanian preschool education regarding their role in ensuring the well-being of preschoolers in kindergarten, in the context of the COVID-19 pandemic. Thus, starting from the theoretical framework that delimits the factors that influence the well-being at this age (Aulia et al., 2020; Kwi-Ok et al., 2020; Sönmez \& Ceylan, 2016), we used The Scale of Self-assessment of Wellbeing - IASB (Rodawell, 2019), developed by the University of Bucharest within the Rodawell project, and The Scale of Happiness Strategies for Children Used by Preschool Teachers - HSCPT (Sapsağlam et al., 2019). The online questionnaire was answered by 149 teachers for preschool education, especially from Timis county. The results of the study (analyzed by The Independent-Samples T-Test, ANOVA One-Way, Spearman Correlation) highlight the existence of a positive association between perceptions and practices of educators in ensuring wellbeing, but also the existence of statistically significant differences between teachers' practices in urban vs. rural environment, in the sense that, although they perceive children's well-being similarly, rural teachers tend to use happiness strategies more often. At the same time, teachers' perceptions differ depending on how the teaching activity is carried out in a pandemic context: the self-perceived role and the practices dedicated to ensuring well-being are more intense in hybrid and online format than the traditional one. 
Keywords: children's well-being, Covid-19 pandemic, happiness strategies for children, preschool education, teachers' perception.

\section{Introducere}

Perioada pandemică pe care o traversăm a adus provocări considerabile asupra stării de bine a tuturor, accentuând rolul specialiştilor şi practicienilor pentru a o asigura şi men ine, atât în context educa ional desfăşurat de la distan ă, cât şi în afara sa.

Asigurarea stării de bine a educabililor devine o problematică tot mai des abordată de to i factorii interesa i: cercetători, profesori, politicieni, consilieri, practicieni, beneficiari etc. Astfel, OECD, ca viziune a educa iei 2030, defineşte educa ia de calitate în termeni de asigurare a bunăstării educabilului, atât la nivel individual, cât şi societal (OECDb, 2019). În 2015, liderii mondiali au adoptat Agenda 2030 pentru Dezvoltare Durabilă cu obiectivul nr. 3 stipulând asigurarea ,unei vie i sănătoase şi promovarea bunăstării tuturor, la orice vârstă” (Na iunile Unite, 2018). La nivel na ional, a fost introdus criteriul nr. 4 ca parte a procesului de evaluare institu ională: „In ce măsură şcoala asigură starea de bine a participan ilor la educa ie?" (ARACIP, 2021, p. 4), prevăzut în noile standarde de asigurare a calită ii educa iei în învă ământul preuniversitar românesc.

Studiile interna ionale accentuează această problematică, fiind sistematic investigată în testările interna ionale. Astfel, studiile PISA eviden iază nevoia de a aborda de timpuriu acest aspect problematic, prezentând drept urmări efectele negative, în creştere, ale lipsei stării de bine în şcoală: în 2012, $22,7 \%$ dintre elevii români se declarau neferici i la şcoală, comparativ cu procentul interna ional de 16,3\% (OECD, 2012), iar în 2018, 40\% se sim eau uneori sau întotdeauna trişti, speria i (33\%), nesiguri (35\%) şi temători (30\%) la şcoală, comparativ cu media de $40 \%$ a sondajului interna ional (OECD, 2019). Constatăm că această creştere s-a produs atât la nivel na ional, cât şi interna ional, iar încadrarea elevilor români în media etalon nu minimalizează amplitudinea fenomenului, care necesită, desigur, măsuri ameliorative ferme. Astfel, 49\% dintre tinerii români consideră că îmbunătă irea sănătă ii şi bunăstării ar trebui să devină o prioritate pentru U.E. în anii următori, 
comparativ cu media de $44 \%$ a UE (Comisia Europeană, 2019). În plus, dacă acestea erau datele înainte de perioada pandemică, se discută tot mai intens că aceasta a contribuit la intensificarea problematicii, urmările fiind de aşteptat să se manifeste inclusiv câ iva ani după încheierea pandemiei. Aspectele evocate sunt argumente pentru care profesorii trebuie să fie abilita i şi sensibiliza i asupra problematicii asigurării sistematice a stării de bine a educabililor, la toate nivelurile de şcolaritate.

Preocupări privind identificarea şi dezvoltarea de solu ii metodologice ameliorative au fost recent în aten ia specialiştilor de la Universitatea din Bucureşti, în cadrul proiectului Rodawell (Ciolan et al., 2019; Nedelcu et al., 2018). Ne propunem să investigăm, folosind instrumentul dezvoltat în acest proiect şi etalonat pe popula ia românească, care sunt percep iile profesorilor de învă ământ preşcolar, cu privire la rolul lor în asigurarea stării de bine a preşcolarilor, respectiv cu ce extensie şi cum, prin practicile lor didactice, stimulează aceasta. Pentru a identifica şi cum o fac, ce strategii didactice de înveselire a copiilor folosesc, cât de des, am aplicat şi The Scale of Happiness Strategies for Children Used by Preschool Teachers - HSCPT (Sapsağlam et al., 2019), tradus şi validat de noi pentru popula ia românească. Procedând în această manieră, am putut ob ine o diagnoză cu privire la atitudinea educatorilor fa ă de abordarea nevoilor socio-emo ionale ale copiilor, respectiv o autoapreciere referitoare la frecven a utilizării unor strategii de asigurare a bunăstării şi contextele aferente în care acestea sunt valorificate. Studiul constatativ este un punct de pornire, un referen ial, pentru interven ii formative ulterioare asupra profesorilor din învă ământul preşcolar şi asupra educabililor lor.

\section{Cadrul teoretic}

2.1. Starea de bine

Starea de bine - wellbeing - este un concept dificil de definit sau de opera ionalizat, recunoscut ca un construct complex şi multidimensional, ce include atât componente materiale, obiective, cât şi fa ete psihologice, subiective (OECD, 2019). Conceptul se referă la calitatea vie ii unei persoane în termeni de sănătate şi siguran ă, bunăstare materială, acces la educa ie 
sau la servicii sociale de calitate (Mashford-Scott et al., 2012; Rodawell, 2019), fiind asociat frecvent cu concepte precum ,fericire”, „calitatea vie ii”, ,satisfac ia vie ii”, ,inteligen a emo ională”, , sănătatea mintală” sau „bunăstare” (Aulia et al., 2020; Lewis, 2019; Nedelcu et al., 2018; Pollard \& Lee, 2003; Williams-Brown \& Mander, 2020). Drept urmare, starea de bine nu este o stare înnăscută, fixă sau permanentă, ci o stare dinamică ce poate fi antrenată, poate evolua în timp şi contexte (IBO, 2021).

Potrivit metaanalizelor lui Pollard \& Lee (2003) şi Aulia şi colaboratorii (2020), starea de bine nu este definită în mod consecvent şi nu există un acord cu privire la cea mai bună modalitate de măsurare a acesteia în rândul educabililor, de obicei fiind abordate 5 dimensiuni cheie: bunăstare fizică, psihologică, cognitivă, socială şi economică. Aulia şi colaboratorii (2020) constată faptul că defini ia bunăstării elevilor tinde să se concentreze mai degrabă pe aspectele pozitive ale stării de bine decât pe aspectele negative, iar în majoritatea studiilor analizate, starea de bine este identificată prin 4 aspecte principale: emo ie pozitivă, rela ii sociale, lipsa emo iei negative (anxietate, frici) şi implicarea la şcoală (angajament cognitiv, emo ional şi comportamental), la care se adaugă alte două aspecte secundare: factorii intrapersonali (stima de sine, autoeficacitatea), respectiv realizarea (capacitatea de a finaliza sarcinile zilnice, de a-şi atinge obiectivele de studiu şi de a fi competent). De asemenea, de-a lungul timpului sau conturat o serie de modele teoretice, explicative, precum: Modelul PERMA (Seligman, 2011); Modelul lui Allardt (INSP, 2019); Modelul finlandez al stării de bine în şcoală (Konu \& Rimpela, 2002), şi nu în ultimul rând, modelul asupra căruia ne vom opri în cadrul lucrării: Modelul Româno-Danez al stării de bine (Nedelcu et al., 2018; Ciolan et al., 2019), ce explică existen a bunăstării prin intermediul a patru factori: interac iune, autonomie, mediu de învă are şi incluziune.

În ciuda multor conceptualizări, cercetările au ajuns la concluzia că acest concept de stare de bine a copiilor preşcolari are un slab fundament teoretic (Mashford-Scott et al., 2012; Nedelcu et al., 2018; Pollard \& Lee, 2003; Raghavan \& Alexandrova, 2015; Statham \& Chase, 2010), identificând o lipsă de consens între culturi, limbi şi discipline (Ciolan et al., 2019; Kwi-Ok et al., 2020; Statham \& Chase, 2010), deoarece conceptul „provine din viziunea dominantă şi de lungă durată a copiilor ca viitori adul $i$, care, ca urmare, nu necesită o teorie proprie” (Raghavan \& Alexandrova, 2015, p. 893). 
Raportându-ne la contextul na ional, starea actuală a cunoaşterii referitoare la problematica identificată prezintă lacune accentuate: în conceptualizarea bunăstării copiilor în literatura românească, în corpul de cunoştin e pe această temă specifică în contextul educa ional românesc, în opera ionalizarea conceptului pentru studiu şi pentru o utilizare eficientă în practicile educa ionale (Ciolan et al., 2019). Aşadar, vom folosi accep iunea de stare de bine, respectiv de bunăstare pentru a descrie calitatea vie ii educa ionale preşcolare $c u$ accent pe analiza dimensiunii subiective a acesteia, dat fiind faptul că la copiii preşcolari nu avemîn vedere toate dimensiunile integrative ale conceptului analizat, respectiv suntem consonan i cu studiul na ional RODAWELL (Nedelcu et al., 2018), care a abordat problematica stării de bine la această vârstă, contribuind semnificativ la avansarea conceptualizării problematicii în spa iul românesc.

2.2. Atitudinea educatorilor fa ă de abordarea nevoilor socioemo ionale ale copiilor

Atitudinea educatorilor joacă un rol important în întregul proces de asigurare a bunăstării copiilor. În structura atitudinii se identifică ,o componentă afectivă (aspectul central al atitudinii), o componentă cognitivă (componenta fundamentală), o componentă comportamentală (de care va depinde situarea activă sau pasivă în raport cu obiectul atitudinii) şi, nu în ultimul rând, o componentă evaluativă care înglobează toate aceste atribute" (Marineanu, 2013, p.21).

Studiile efectuate în acest sens au arătat că majoritatea cadrelor didactice manifestă, în general, o atitudine pozitivă fa ă de bunăstare şi fa ă de oportunită ile de a facilita starea de bine în rândul copiilor, alegând imediat să intervină dacă parametrii bunăstării sunt în general negativi (Sönmez \& Ceylan, 2016). În elegerea generală a conceptului de stare de bine în rândul educatorilor este strâns legată de fericire, satisfac ie şi co-participare (Ben-Arieh et al., 2014). Modul în care educatorii satisfac nevoile sociale, emo ionale şi fizice ale copiilor, propria lor disponibilitate de a se implica în activită ile de joc ale acestora, dezvoltarea sentimentului de apartenen ă, respectul şi capacitatea acestora de a stabili rela ii pozitive sunt de mare importan ă pentru calitatea vie ii preşcolarilor (Williams-Brown \& Mander, 2020). Nevoile social-emo ionale sunt atinse şi starea de bine a copiilor este îmbunătă ită atunci când autonomia, ini iativa, 
implicarea şi controlul asumat sunt încurajate în jocul celor mici, cu o interven ie minimă a adul ilor; când mediul educa ional este unul incluziv, stimulativ, provocator, dar sigur, ce furnizează oportunită i de joc, varietă i de jocuri şi jucării; şi când sunt încurajate permanent interac iuni pozitive între copii, între profesori şi copii, ce conduc, astfel, la închegarea unor rela ii sigure, conferind stabilitate socio-emo ională (Bjørgen, 2015; Kwi-Ok et al., 2020). Astfel, putem corela cei patru factori componen i ai stării de bine (Nedelcu et al., 2018) cu patru roluri principale ale educatorului în crearea bunăstării educa ionale în grădini a de copii: rolul de a dezvolta un comportament autonom, rolul de a stabili rela ii şi interac iuni pozitive cu şi între preşcolari, rolul de a asigura un mediu de învă are autentic şi rolul de a crea un mediu educa ional incluziv.

\section{Metodologie}

Lucrarea de fa ă prezintă un design cantitativ, non-experimental, de tip corela ional şi comparativ, în baza căruia am căutat să identificăm cum autoapreciază profesorii din învă ământul preşcolar rolul şi practicile lor pentru asigurarea stării de bine a preşcolarilor.

În acest sens, între 8 şi 24 martie 2021 am chestionat online, prin intermediul Formularelor Google, profesori pentru învă ământ preşcolar, apelând la un mijloc rapid, convenabil şi gratuit de colectare a datelor, indiferent de zona geografică, care nu identifică nicio informa ie despre responden i, asigurând confiden ialitatea datelor şi premisele pentru răspunsuri oneste. Distribuirea chestionarului s-a realizat prin postări pe pagini de interes: grupuri ale educatorilor, e-mail-uri trimise profesorilor sau institu iilor de învă ământ, asigurându-se consim ământul responden ilor.

149 de profesori au oferit răspunsuri valide. Cei mai mul i dintre aceştia $(40,9 \%)$ au vârste cuprinse între 36 şi 45 de ani, respectiv 26,2\% sunt între 26 şi 35 de ani. Participan ii sunt de gen feminin în propor ie de $100 \%$, reflectând structura ocupa ională din România pentru această profesie; provin din 10 jude e şi predau la grădini e de stat $(96,6 \%)$ sau private $(3,4 \%)$, aflate atât în medii urbane $(72,5 \%)$, cât şi în medii rurale (27,5\%). Dintre cei 149 de educatori, 130 sunt din jude ul Timiş $(87,2 \%)$ şi doar 19 din alte jude e (12,8\%). $125(83,9 \%)$ îşi desfăşoară 
activitatea în grădini e cu program prelungit, $23(15,4 \%)$ în unită i de învă ământ preşcolar cu program normal şi doar $1(0,7 \%)$ în grădini e cu program săptămânal. Adi ional acestor date, Tabelul 1 prezintă sintetizat distribu ia eşantionului şi caracteristicile responden ilor.

Tabelul nr. 1. Distribu ia eşantionului pe baza datelor socio-demografice colectate

\begin{tabular}{|c|c|c|}
\hline Date socio-demografice categoriale & Frecven $\mathrm{a}(\mathrm{N})$ & Procentaj(\%) \\
\hline \multicolumn{3}{|l|}{ Genul } \\
\hline Feminin & 149 & 100 \\
\hline Masculin & 0 & 0 \\
\hline \multicolumn{3}{|l|}{ Vârsta } \\
\hline sub 25 de ani & 18 & 12.1 \\
\hline între 26 şi 35 de ani & 39 & 26.2 \\
\hline între 36 şi 45 de ani & 61 & 40.9 \\
\hline între 46 şi 55 de ani & 20 & 13.4 \\
\hline peste 56 de ani & 11 & 7.4 \\
\hline \multicolumn{3}{|l|}{ Vechimea în învă ământ } \\
\hline mai pu in de 1 an & 9 & 6 \\
\hline $1-3$ ani & 21 & 14.1 \\
\hline 4-10 ani & 28 & 18.8 \\
\hline $11-25$ ani & 65 & 43.6 \\
\hline peste 25 ani & 26 & 17.4 \\
\hline \multicolumn{3}{|l|}{ Gradul didactic } \\
\hline Debutant & 26 & 17.4 \\
\hline Definitivat & 24 & 16.1 \\
\hline Gradul II & 24 & 16.1 \\
\hline Gradul I & 75 & 50.3 \\
\hline \multicolumn{3}{|l|}{ Tipul institu iei } \\
\hline De stat & 144 & 96.6 \\
\hline Privată & 5 & 3.4 \\
\hline \multicolumn{3}{|l|}{ Tipul de program al grădini ei } \\
\hline Program Normal & 23 & 15.4 \\
\hline Program Prelungit & 125 & 83.9 \\
\hline Program Săptămânal & 1 & 0.7 \\
\hline \multicolumn{3}{|c|}{ Mediul de reziden ă al institu iei de învă ământ } \\
\hline Rural & 41 & 27.5 \\
\hline Urban & 108 & 72.5 \\
\hline \multicolumn{3}{|l|}{ Jude ul } \\
\hline Timiş & 130 & 87.2 \\
\hline Altele & 19 & 12.8 \\
\hline \multicolumn{3}{|l|}{ Grupa (nivelul de vârstă) } \\
\hline mică (3-4 ani) & 37 & 24.8 \\
\hline mijlocie (4-5 ani) & 38 & 25.5 \\
\hline mare (5-6 ani) & 55 & 36.9 \\
\hline mixtă (combinată) & 19 & 12.8 \\
\hline \multicolumn{3}{|c|}{ Scenariul de desfăşurare a activită ii didactice în perioada pandemică din luna Februarie 2021} \\
\hline exclusiv online & 8 & 5.4 \\
\hline exclusiv fa ă în fa ă & 58 & 38.9 \\
\hline fa ă în fa ă şi online & 83 & 55.7 \\
\hline
\end{tabular}


Datele au fost colectate utilizând două chestionare: Instrumentul de autoevaluare a stării de bine (IASB), dezvoltat de Centrul Educa ional Româno-Danez pentru Starea de Bine a Copiilor (Ciolan et al., 2019) şi The Scale of Happiness Strategies for Children Used by Preschool Teachers (HSCPT), elaborat de Sapsağlam şi colaboratorii (2019).

Instrumentul de autoevaluare a stării de bine (IASB) a fost folosit pentru a evalua percep iile cadrelor didactice din grădini e privind rolul lor în asigurarea stării de bine a copiilor preşcolari. Chestionarul conceput, testat şi validat pe popula ia românească cuprinde 16 itemi împărti i pe 4 factori de evaluare a percep iei educatorilor fa ă de asigurarea bunăstării preşcolarilor: F1 interac iune; F2 - autonomie; F3 - mediu de învă are şi F4 - incluziune. Acesta este alcătuit din afirma ii formulate într-o manieră pozitivă cu răspunsuri măsurate cu ajutorul Scalei Likert cu 6 trepte, variind de la: $0=$ Deloc, la $5=\hat{\text { In }}$ totalitate . Acordul pentru utilizarea acestui instrument a fost ob inut de la dezvoltatorii instrumentului, Facultatea de Psihologie şi Ştiin ele Educa iei a Universită ii din Bucureşti, în data de 08.02.2021.

Cel de-al doilea chestionar, Strategii de inveselire a copiilor folosite de profesorii din învă ământul preşcolar (HSCPT), a fost utilizat pentru a evalua frecven a strategiilor folosite de educatori în scopul creării unui climat educa ional pozitiv cu stare de bine, fericire şi emo ii pozitive. Scala cuprinde 12 itemi împăr i i pe 3 dimensiuni de evaluare a strategiilor de înveselire: D1 - rela ii pozitive cu copiii; D2 - satisfacerea dorin elor copiilor şi D3 joaca cu copiii. Dezvoltatorii instrumentului, Sapsağlam şi colaboratorii (2019), prezintă o fiabilitate de .93 per scală şi .92 pentru prima dimensiune, .91 pentru a doua dimensiune, .80 pentru a treia dimensiune. Acesta este alcătuit din afirma ii formulate într-o manieră pozitivă, măsurate cu ajutorul Scalei Likert cu 5 trepte, variind de la: $0=$ Aproape niciodată, la $4=\hat{I n t o t d e a u n a}$. HSCPT nu a fost încă validat pe popula ia românească. În vederea traducerii în limba română şi adaptării culturale a scalei de măsurare a frecven ei practicilor folosite de educatori, am derulat o procedură de traducere a instrumentului prin tehnica retroversiunii, ob inând o bună fiabilitate pe scală (.93) şi pe subscale (.89 pentru prima dimensiune, .78 pentru cea de-a doua şi .91 pentru ultima dimensiune).

Datele descriptive şi datele privind corela iile, respectiv diferen ele dintre 
percep iile practicienilor asupra bunăstării copiilor şi rolurile lor în facilitarea stării de bine a preşcolarilor în institu iile de învă ământ au fost analizate cu ajutorului programul IBM SPSS AMOS 23 (Arbuckle, 2014) şi JASP Team (2020). JASP (Versiunea 0.14.1) [Computer software].

Analiza datelor a permis verificarea următoarelor ipoteze:

1. Există o legătură între percep iile educatorilor privind starea de bine evaluată la nivelul grupei de preşcolari şi utilizarea unor strategii în acest sens.

2. Nu există diferen e semnificative statistic între educatorii care activează în mediul rural şi cei care activează în mediul urban privind percep iile şi practicile acestora în privin a asigurării stării de bine a preşcolarilor.

3. $\mathrm{Nu}$ există diferen e semnificative statistic în func ie de experien a în învă ământ (vechime şi grad didactic) a educatorilor în ceea ce priveşte percep iile şi strategiile folosite în vederea asigurării stării de bine a copiilor preşcolari.

4. Există diferen e semnificative statistic între practicile şi percep iile educatorilor privind asigurarea stării de bine a copiilor în func ie de modalitatea de desfăşurare a activită ii didactice, impusă de contextul pandemic.

\section{Rezultatele cercetării}

În urma efectuării statisticilor descriptive pentru fiecare variabilă, a reieşit o distribu ie neuniformă a datelor şi o omogenitate a varian elor, ceea ce permite folosirea testelor statistice parametrice: Corela ia Spearman, Testul-T pentru două eşantioane independente şi ANOVA One-Way, ale căror rezultate sunt prezentate pe larg în Tabelele 2-6.

Pentru verificarea primei ipoteze am utilizat Corela ia Spearman, ob inând drept rezultat existen a unei legături pozitive între cele două variabile analizate: percep iile profesorilor asupra stării de bine prezente în sala de grupă şi strategiile de asigurare a bunăstării. Corela ia este semnificativă statistic la pragul de .01, unde $\rho(147)=.474, \rho^{2}=.224, \mathrm{p}<.001$ (Tabelul 2). Ca atare, $22,4 \%$ din varia ia unei variabile poate fi explicată de varia ia celeilalte variabile şi invers. Mai exact, educatorii care percep un nivel ridicat al stării de bine în 
rândul preşcolarilor tind să utilizeze mai frecvent strategiile de asigurare a bunăstării copiilor şi invers. Astfel, prima ipoteză se confirmă.

Tabelul nr. 2. Analiza corela ională între cele două variabile: IASB şi HSCPT

\begin{tabular}{ccc} 
Variabilele asociate & $N$ & \\
\hline $\begin{array}{c}\text { Percep iile educatorilor privind asigurarea } \\
\text { stării de bine a copiilor }\end{array}$ & 149 & $\begin{array}{c}\text { Strategii de înveselire folosite } \\
\text { de educatori }\end{array}$ \\
\hline
\end{tabular}

** Corela ia este semnificativă la pragul de 0.01 (2-tailed)

În urma aplicării Testului T pentru 2 eşantioane independente rezultă, conform Tabelului 3, că nu există diferen e semnificative statistic între profesorii care predau în mediul rural $(M=3.81, S D=.87)$ şi cei care activează în mediul urban $(M=3.71, S D=.94)$, privind percep iile acestora asupra asigurării stării de bine a preşcolarilor, pentru toate cele 4 dimensiuni: interac iune $\left(\mathrm{t}_{(147)}=.11\right.$, $\mathrm{p}>.05)$, autonomie $\left(\mathrm{t}_{(147)}=.69, \mathrm{p}>.05\right)$, mediu de învă are $\left(\mathrm{t}_{(147)}=.62, \mathrm{p}>.05\right)$, incluziune $\left(\mathrm{t}_{(147)}=.22, \mathrm{p}>.05\right)$, cât şi pentru media acestora $\left(\mathrm{t}_{(147)}=.60, \mathrm{p}>.05\right)$.

În urma aplicării Testului T pentru eşantioane independente rezultă că există diferen e semnificative statistic între educatorii din mediul urban şi mediul rural în privin a frecven ei utilizării strategiilor de asigurare a stării de bine a copiilor pentru toate cele 3 dimensiuni: rela ii pozitive $\left(\mathrm{t}_{(147)}=2.93, p<.01\right.$, $\mathrm{d}=.49)$, satisfacerea dorin elor copiilor $\left(\mathrm{t}_{(147)}=3.24, p<.01, \mathrm{~d}=.62\right)$, joaca cu copiii $\left(\mathrm{t}_{(147)}=3.02, p<.01, \mathrm{~d}=.59\right)$, cât şi pentru media acestora $\left(\mathrm{t}_{(147)}=3.31\right.$, $p<.01, \mathrm{~d}=.65)$, unde mărimea efectului este una medie. Cadrele didactice care activează în mediul rural au ob inut scoruri mai mari în compara ie cu cei care activează în mediul urban pentru toate cele 3 tipuri de strategii: de rela ionare pozitivă - încurajări, laude şi aprecieri $(M=3.81, S D=.39$ fa ă de $M=3.57, S D=.57$ ), de satisfacere a dorin elor copiilor - bonusuri, recompense, surprize, aten ie şi receptivitate la solicitările de moment ale copiilor $(M=3.42, S D=.57$ fa ă de $M=3.04, S D=.64)$ şi de joacă împreună cu copiii - participare la jocurile preferate ale celor mici, la activită ile de dans/ muzicale sau cele ini iate de copii $(M=3.59, S D=.49$ fa ă de $M=3.25$, $S D=.65$ ), iar aceste diferen e sunt medii (Tabel 3). Aşadar, ipoteza 2 se confirmă par ial, la nivelul percep iilor educatorilor, nu şi al practicilor. 
Tabelul nr. 3. Rezultatele testelor T pentru analiza diferen elor dintre educatorii din mediul rural şi cei din mediul urban, privind asigurarea stării de bine a copiilor şi frecven a utilizării strategiilor specifice

\begin{tabular}{|c|c|c|c|c|c|c|c|c|}
\hline \multirow{3}{*}{$\begin{array}{l}\text { Dimensiuni/factori } \\
\text { ai stării de bine }\end{array}$} & \multicolumn{4}{|c|}{ Mediul de provenien $\breve{a}$} & \multirow[t]{2}{*}{$t$} & \multirow[t]{2}{*}{$d f$} & \multirow[t]{2}{*}{$p$} & \multirow[t]{2}{*}{$d$} \\
\hline & \multicolumn{2}{|c|}{$\begin{array}{c}\text { rural } \\
(N=41)\end{array}$} & \multicolumn{2}{|c|}{$\begin{array}{c}\text { urban } \\
(N=108)\end{array}$} & & & & \\
\hline & $M$ & $S D$ & $M$ & $S D$ & & & & \\
\hline $\begin{array}{c}\text { Percep ia } \\
\text { educatorilor fa ă de } \\
\text { asigurarea stării de } \\
\text { bine a copiilor }\end{array}$ & 3.81 & .87 & 3.71 & .94 & 0.60 & 147 & .55 & - \\
\hline F1-Interac iune & 3.92 & .86 & 3.90 & .95 & .11 & 147 & .91 & - \\
\hline F2-Autonomie & 3.40 & .97 & 3.32 & 1.02 & .39 & 147 & .69 & - \\
\hline $\begin{array}{l}\text { F3-Mediu de } \\
\text { invă are }\end{array}$ & 4 & .93 & 3.91 & 1.01 & .49 & 147 & .62 & - \\
\hline F4-Incluziune & 3.92 & 1.01 & 3.70 & 0.99 & 1.23 & 147 & .22 & - \\
\hline $\begin{array}{c}\text { Strategii de } \\
\text { asigurare a stării } \\
\text { de bine }\end{array}$ & 3.61 & .42 & 3.29 & .55 & 3.31 & 147 & $.001 * *$ & .65 \\
\hline $\begin{array}{l}\text { Dl-Rela ii } \\
\text { pozitive }\end{array}$ & 3.81 & .39 & 3.57 & .57 & 2.93 & 147 & $.004 * *$ & .49 \\
\hline $\begin{array}{c}\text { D2-Satisfacerea } \\
\text { dorin elor } \\
\text { copiilor }\end{array}$ & 3.42 & .57 & 3.04 & .64 & 3.24 & 147 & $.001 * *$ & .62 \\
\hline $\begin{array}{c}\text { F4-Joaca cu } \\
\text { copiii }\end{array}$ & 3.59 & .49 & 3.25 & .65 & 3.01 & 147 & $.003 * *$ & .59 \\
\hline
\end{tabular}

Notă: semnificativ *p<.05; **p<.01.

Legendă: $t$-diferen a dintre cele două grupuri, $d f$-gradele de libertate, $p$-pragul de semnifica ie, $d$-mărimea efectului.

Pentru a determina dacă există o diferen ă semnificativă statistic în func ie de experien a în învă ământ (vechime şi grad didactic) a educatorilor în ceea ce priveşte percep iile şi strategiile folosite, în vederea asigurării stării de bine a copiilor preşcolari, am aplicat Testul ANOVA simplă (Tabelul 4 şi Tabelul 5). În urma analizei post-hoc Hochberg, rezultă că nu există diferen e semnificative statistic între cadrele didactice în func ie de vechimea în învă ământ a acestora, în privin a modului în care îşi percep rolul în 
asigurarea stării de bine a preşcolarilor $(\mathrm{F}=2.04, \mathrm{p}>.05)$, respectiv în privin a frecven ei utilizării strategiilor de înveselire $(\mathrm{F}=.09, \mathrm{p}>.05)$. De asemenea, diferen ele nesemnificative dintre grupurile de educatori se păstrează dacă avem în vedere variabila independentă gradul didactic al profesorilor, ob indând un scor de $\mathrm{F}=.40, \mathrm{p}>.05$ pentru percep iile educatorilor şi un scor de $\mathrm{F}=.09, \mathrm{p}>.05$ pentru strategiile de înveselire analizate. Aşadar, presupunerea noastră (ipoteza 3) se confirmă, fapt care demonstrează o practică didactică asemănătoare a educatorilor debutan i cu cea a profesorilor experimenta i, cu o vechime considerabilă în învă ământ, atât la nivelul strategiilor de înveselire, cât şi a modului în care percep rolul lor în asigurarea stării de bine a copiilor.

Tabelul nr. 4. Testul ANOVA simplă pentru percep ia educatorilor asupra asigurării stării de bine şi frecven a utilizării strategiilor de înveselire, în func ie de vechimea în învă ământ

\begin{tabular}{|c|c|c|c|c|c|c|c|c|c|c|c|c|c|}
\hline & \multicolumn{10}{|c|}{ Vechimea în învă ământ } & \multirow{3}{*}{$F$} & \multirow{3}{*}{$p$} & \multirow{3}{*}{$d$} \\
\hline & \multicolumn{2}{|c|}{$\begin{array}{c}\text { mai pu in de } \\
1 \text { an } \\
(N=9)\end{array}$} & \multicolumn{2}{|c|}{$\begin{array}{l}1-3 \text { ani } \\
(N=21)\end{array}$} & \multicolumn{2}{|c|}{$\begin{array}{l}\text { 4-10 ani } \\
(N=28)\end{array}$} & \multicolumn{2}{|c|}{$\begin{array}{c}11-25 \text { ani } \\
(N=65)\end{array}$} & \multicolumn{2}{|c|}{$\begin{array}{c}\text { peste } 25 \text { ani } \\
\quad(N=26)\end{array}$} & & & \\
\hline & $M$ & $A S$ & $M$ & $A S$ & $M$ & $A S$ & $M$ & $A S$ & $M$ & $A S$ & & & \\
\hline $\begin{array}{l}\text { Percep ia asupra } \\
\text { asigurării stării } \\
\text { de bine a } \\
\text { preşcolarilor }\end{array}$ & 3.60 & .69 & 4.1 & .65 & 3.5 & .94 & 3.64 & .98 & 3.98 & .88 & 2.04 & .09 & - \\
\hline $\begin{array}{l}\text { Strategii de } \\
\text { înveselire }\end{array}$ & 3.55 & .39 & 3.52 & .37 & 3.32 & .60 & 3.31 & .59 & 3.42 & .48 & .09 & .44 & - \\
\hline
\end{tabular}

Notă: Diferen ă nesemnificativă a percep iei fa $\breve{a}$ de asigurarea stării de bine şi a frecven ei utilizării strategiilor specifice, în func ie de vechimea în învă ământ: (a) mai pu in de 1 an, (b) 1-3 ani, (c) 4-10 ani, (d) 11-25 ani, (e) peste 25 ani; în func ie de rezultatele ob inute $\hat{\imath}$ urma analizei post-hoc Hochberg. 
Tabelul nr. 5. Testul ANOVA simplă pentru percep ia educatorilor asupra asigurării stării de bine şi frecven a utilizării strategiilor de înveselire, în func ie de gradul didactic

\begin{tabular}{|c|c|c|c|c|c|c|c|c|c|c|c|}
\hline & \multicolumn{8}{|c|}{ Gradul didactic } & \multirow{3}{*}{$F$} & \multirow{3}{*}{$p$} & \multirow{3}{*}{$d$} \\
\hline & \multicolumn{2}{|c|}{$\begin{array}{c}\text { Debutant } \\
(N=26)\end{array}$} & \multicolumn{2}{|c|}{$\begin{array}{l}\text { Definitivat } \\
\quad(N=24)\end{array}$} & \multicolumn{2}{|c|}{$\begin{array}{l}\text { Gradul II } \\
(N=24)\end{array}$} & \multicolumn{2}{|c|}{$\begin{array}{l}\text { Gradul I } \\
(N=75)\end{array}$} & & & \\
\hline & $M$ & $A S$ & $M$ & $A S$ & $M$ & $A S$ & $M$ & $A S$ & & & \\
\hline $\begin{array}{c}\text { Percep ia asupra } \\
\text { asigurării stării de } \\
\text { bine a preşcolarilor }\end{array}$ & 3.79 & .92 & 3.61 & .84 & 3.89 & .93 & 3.71 & .94 & 0.40 & .75 & - \\
\hline Strategii de înveselire & 3.43 & .57 & 3.48 & .36 & 3.38 & .58 & 3.32 & .56 & 0.70 & .55 & - \\
\hline
\end{tabular}

Notă: Diferen ă nesemnificativă a percep iei fa $\breve{a}$ de asigurarea stării de bine şi a frecven ei utilizării strategiilor specifice, în func ie de gradul didactic: (a) debutant, (b) definitivat, (c) gradul II, (d) gradul I, în func ie de rezultatele ob inute în urma analizei post-hoc Hochberg.

Pentru a determina dacă există diferen e între practicile şi percep iile educatorilor privind asigurarea stării de bine a copiilor în func ie de modalitatea de desfăşurare a activită ii didactice impusă de contextul pandemic (exclusiv fa ă în fa ă, exclusiv online, fa ă în fa ă şi online), am aplicat Testul ANOVA simplă (Tabelul 6). În urma analizei post-hoc Hochberg, rezultă că există diferen e între percep iile profesorilor $(F=6.08, \mathrm{p}<.05, \mathrm{~d}=.05)$ şi practicile acestora $(F=2.78, \mathrm{p}>.05)$ în func ie de variabila independentă (scenariul pandemic adoptat), însă aceste diferen e se dovedesc a fi semnificative statistic doar în privin a primei variabile dependente: percep ia asupra asigurării stării de bine a preşcolarilor. Educatorii care au predat în format online au evaluat mai bine eforturile lor în asigurarea stării de bine a copiilor, comparativ cu cei care au predat în format hibrid, respectiv comparativ cu cei care au predat exclusiv fa ă în fa ă. Cu toate acestea, educatorii spun că au aplicat la fel de frecvent toate cele trei tipuri de strategii de înveselire, indiferent de modalitatea de desfăşurare a activită ii didactice. În acest caz, ipoteza 4 se confirmă par ial, existând diferen e semnificative statistic între percep iile educatorilor care şi-au desfăşurat activitatea didactică exclusiv fa ă în fa $\breve{a}$ şi cei care şi-au desfăşurat activitatea atât $f a \breve{a}$ în $f a \breve{a}$, cât şi online, respectiv între cei care au activat exclusiv fa $\breve{a}$ in fa $\breve{a}$ şi cei care au predat exclusiv online. 
Tabelul nr. 6. Testul ANOVA simplă pentru percep ia educatorilor asupra asigurării stării de bine şi frecven a utilizării strategiilor de înveselire, în func ie scenariul pandemic adoptat privind desfăşurarea activi $\breve{a}$ ii didactice din grădini a de copii

\begin{tabular}{|c|c|c|c|c|c|c|c|c|c|}
\hline & \multicolumn{6}{|c|}{ Modalitatea de desfăşurare a activită ii didactice } & \multirow{3}{*}{$F$} & \multirow{3}{*}{$p$} & \multirow{3}{*}{$d$} \\
\hline & \multicolumn{2}{|c|}{$\begin{array}{c}\text { exclusiv fa ă în } \\
\text { fa ă } \\
(N=58)\end{array}$} & \multicolumn{2}{|c|}{$\begin{array}{c}\text { fa ă în fa ă şi } \\
\text { online } \\
(N=83)\end{array}$} & \multicolumn{2}{|c|}{$\begin{array}{l}\text { exclusiv } \\
\text { online } \\
(N=8)\end{array}$} & & & \\
\hline & $M$ & $A S$ & $M$ & $A S$ & $M$ & $A S$ & & & \\
\hline $\begin{array}{c}\text { Percep ia asupra } \\
\text { asigurării stării de } \\
\text { bine a preşcolarilor }\end{array}$ & 3.44 & .99 & 3.89 & .82 & 4.29 & 69 & 6.08 & .003 & .05 \\
\hline Strategii de înveselire & 3.32 & .56 & 3.37 & .53 & 3.8 & .25 & 2.78 & .06 & - \\
\hline
\end{tabular}

Notă: Diferen ă semnificativă a percep iei fa $\breve{a}$ de asigurarea stării de bine în func ie de modalitatea de desfăşurare a activită ii didactice: (a) exclusiv fa $\breve{a}$ in $f a \breve{a}$, (b) fa $\breve{a}$ in fa $\breve{a}$ şi online (c) exclusiv online, în func ie de rezultatele ob inute în urma analizei post-hoc Hochberg, mai exact între (a) şi (b), respectiv (a) şi (c). Diferen $\breve{a}$ nesemnificativă a frecven ei utilizării startegiilor de bunăstare în func ie de scenariul didactic adoptat.

\section{Discu ii}

Analiza rezultatelor ob inute oferă o serie de date despre practicile şi autoaprecierile profesorilor din învă ământul preşcolar cu privire la maniera în care asigură starea de bine a copiilor la grădini ă.

Astfel, confirmarea primei ipoteze cu privire la existen a unei corela ii pozitive între starea de bine evaluată la nivelul grupei de preşcolari şi utilizarea unor strategii în acest sens reliefează, potrivit itemilor selecta i, aprecierile acestora cu privire la demersurile realizate, care asigură stare de bine. Aceştia aprecieză îmbunătă irea nivelului stării de bine a preşcolarilor ca urmare a unei rela ionări pozitive cu copiii, prin: încurajări frecvente, laude, aprecieri, recunoaşterea eforturilor în fa a întregii grupe, disponibilitate la solicitările de moment ale copiilor. De asemenea, profesorii care au perceput un nivel ridicat al stării de bine în rândul copiilor au raportat practici evidente de satisfacere a dorin elor copiilor, precum: oferirea de recompense, de surprize, de oportunită i de valorificare a intereselor copiilor prin activită i distractive, respectiv practici frecvente de joacă cu copiii, prin participarea 
la activită ile de joc preferate ale copiilor, la activită ile de dans sau la cele muzicale ini iate de preşcolari.

În plus, potrivit datelor care confirmă şi a doua ipoteză, raportându-ne din nou la cele patru dimensiuni de analiză delimitate în proiectul Rodawell (Nedelcu et al., 2018), indiferent de mediul de provenien ă în care activează educatorii, aceştia reuşesc să asigure în aceeaşi măsură o interac iune pozitivă la nivelul grupei de preşcolari, prin strategii precum: stimularea empatiei, respectului, încurajării, coeziunii grupului, sprijinului reciproc, cu o celebrare evidentă a reuşitelor şi o valorificare atentă a greşelilor în procesul ulterior de învă are. Pentru stimularea autonomiei, educatorii apelează, cu extensie comparabilă, la strategii didactice specifice de valorificare a situa iilor reale de învă are, în vederea adaptării copiilor la via a cotidiană; de proiectare a activită ilor în grup împreună cu copiii şi părin ii; de oferire a libertă ii preşcolarilor în realizarea, conducerea şi monitorizarea propriilor activită i de învă are, ca adevăra i lideri ai grupului apar inător. În vederea asigurării unui mediu de învă are autentic, profesorii consideră că sala lor de grupă oferă un sentiment permanent de siguran ă; învă area are loc în contexte diverse, stimulând copiii cognitiv, emo ional şi ac ional, cu o dozare potrivită a efortului, mişcării şi repausului între activită i, iar din punctul de vedere al incluziunii, responden ii confirmă accesul copiilor cu cerin e educative speciale la servicii de suport, cu o organizare flexibilă a activită ilor în vederea integrării tuturor preşcolarilor în grupă, stimulând ataşamentul şi solidaritatea.

Deopotrivă, datele confirmă folosirea strategiilor de înveselire a preşcolarilor, indiferent de experien a didactică (ipoteza 3). Astfel, profesorii debutan i, deopotrivă cu profesorii experimenta i, apreciază că folosesc în mare măsură strategii precum: încurajări, aprecieri, laude, surprize, recompense, aten ie constantă manifestată prin participarea educatorilor la activită ile de joc preferate ale copiilor ori la cele ini iate de aceştia, respectiv prin deschiderea de a-i asculta pe copii de fiecare dată când aceştia îi solicită, iar acestor strategii le-au acordat o şi mai mare importan ă, folosindu-le mai frecvent atunci când s-au aflat la distan ă fa ă de copii, în mediul online (ipoteza 4).

\section{Concluzii}

Studiul de fa ă a fost realizat în contextul unei nevoi crescânde de asigurare 
a unui mediu educa ional pozitiv, în care copilul să se simtă bine din punct de vedere cognitiv, fizic şi emo ional. Astfel, am avut drept scop al cercetării identificarea percep iilor şi practicilor educatorilor privind asigurarea stării de bine a preşcolarilor în grădini a de copii. Rezultatele sunt clare: profesorii manifestă aceeaşi atitudine asupra rolurilor în asigurarea stării de bine în grădini ele de copii, indiferent de experien a educa ională (vechimea în învă ământ), formarea ini ială/continuă (gradul didactic ob inut) sau mediul de provenien ă al institu iei în care aceştia activează (rural/urban). Totodată, s-a demostrat că ar exista o corela ie pozitivă între percep iile cadrelor didactice în asigurarea bunăstării copiilor şi utilizarea unor strategii de influen are a stării de bine, ceea ce înseamnă că, cu cât se utilizează mai des o serie de strategii de înveselire a copiilor, cu atât percep iile profesorilor cu privire la prezen a unui climat educa ional pozitiv, cu stare de bine sunt mai bune.

Pe de altă parte, s-au raportat diferen e semnificative statistic în privin a a două analize comparative efectuate: (1) între practicile cadrelor didactice din mediul rural şi urban în vederea asigurării stării de bine şi (2) între percep iile profesorilor care şi-au desfăşurat activitatea didactică exclusiv fa ă în fa $\breve{a}$ şi cei care au activat atât fa $\breve{a}$ în fa $\breve{a}$ cât şi online, respectiv între cei care au predat fizic şi cei care au predat exclusiv online. Ca atare, educatorii din mediul rural raportează o frecven ă mai mare de utilizare a celor trei tipuri de strategii de înveselire analizate (jocul cu copiii, satisfacerea dorin elor şi dezvoltarea unor rela ii pozitive), comparativ cu cei din mediul urban, iar profesorii care au predat în format hibrid şi exclusiv online manifestă o atitudine mult mai bună asupra rolului lor în asigurarea stării de bine la clasă, comparativ cu cei care au activat doar in format fizic. Aceştia consideră că au depus eforturi mult mai consistente pentru a asigura bunăstarea preşcolarilor în cadrul formatului online şi blended learning, comparativ cu cei care au predat clasic, prin întâlniri exclusive fa ă în fa ă. Educatorii care au activat doar în mediul online au ob inut cel mai mare scor $(M=4.29$, $S D=.69$ ), fiind urma i de cei care au îmbinat cele două alternative: fa ă în fa ă şi online $(M=3.89, S D=.82)$, pe ultimul loc clasându-se formatul tradi ional, fa ă în fa ă $(M=3.44, S D=.99)$. Principalul motiv pentru care tratăm cu precau ie valoarea de adevăr a acestui rezultat este dat de numărul scăzut de responden i (8) care şi-au desfăşurat activitatea didactică exclusiv online. 
De asemenea, rezultatele studiului de fa ă trebuie privite inând seama de principala limită a demersului de cercetare: compozi ia lotului de responden i. Prin faptul că avem un număr relativ mic de responden i, respectiv nu este un eşantion reprezentativ din punct de vedere statistic, nu putem generaliza rezultatele la nivelul întregii popula ii de profesori din învă ământul preşcolar românesc. În acest sens, considerăm utile ca direc ii viitoare de cercetare: a) reluarea studiului pe un eşantion mai mare, reprezentativ de educatori proveni i din toate zonele ării; b) derularea unui studiu calitativ/ mixt de cunoaştere a modalită ilor abordate de profesori în vederea sus inerii bunăstării copiilor pe perioada scenariului roşu (exclusiv online) - formatul care în studiul nostru a ob inut cel mai ridicat scor al percep iilor cadrelor didactice asupra asigurării stării de bine, sau hibrid; c) dezvoltarea unui studiu calitativ de cunoaştere a altor strategii/ metode de influen are a bunăstării copiilor, folosite de profesori la grupă; d) extinderea factorilor de influen ă în crearea unui climat educa ional pozitiv în grădini ele de copii (rezultatele noastre arată că deşi profesorii din mediul rural declară că au folosit mult mai des strategiile de înveselire în compara ie cu educatorii din mediul urban, aceştia au evaluat asemănător climatul educa ional din sala de grupă); e) analiza influen ei stării de bine a profesorilor asupra percep iilor lor în asigurarea stării de bine a copiilor.

Aşadar, studiul de fa ă aduce în discu ie problematica asigurării stării de bine a preşcolarilor, oferind o serie de argumente, date şi abordări investigative utile de folosit ca referen ial reflexiv, ac ional, formativ sau decizional. Demersul investigativ propus este necesar a fi extins şi aprofundat, atât în scop diagnostic, cât şi ameliorativ, fiind o resursă la care se pot raporta viitoare cercetări.

\section{Mul umiri}

Mul umim Prof.univ.dr. Anca Nedelcu, drd. Elena Ungureanu şi echipei de exper i educa ionali din cadrul Universită ii din Bucureşti pentru instrumentul IASB pus la dispozi ie şi sprijinul acordat. 


\section{Referin e}

- Amerijckx, P., \& Humblet, G. (2014). Child well-being: what does it mean? Children \& Society, 28(5), 404-415. https://doi.org/10.1111/chso.12003

- ARACIP. (2021). Ghiduri pentru aplicarea unitară a standardelor de evaluare. Evaluarea internă şi externă a dezvoltării institu ionale. Vol.1.

https://www.isjbn.ro/sites/default/files/documente/2021-02/GHID\%20DE\%20 DEZV.\%20INSTITUTIONALA\%20NR.\%204\%20DIN\%2004.02.2021.pdf

- Arbuckle, J.L. (2014). Amos (Version 23.0) [Computer Program]. IBM SPSS

- Aulia, F., Hastjarjo, T.D., Setiyawati, D., \& Patria, B. (2020). Student Well-being: A Systematic Literature Review. Buletin Psikologi, 28(1), 1-14. https://doi.org/10.22146/buletinpsikologi.42979

- Ben-Arieh, A., Casas, F., Frones, I., \& Korbin, J.E. (2014). Multifaceted Concept of Child Well-Being. In A. Ben-Arieh (Ed.), Handbook of Child Well-Being. Theories, Methods and Policies in Global Perspective (pp.1-27). Springer.

- Bjørgen, K. (2015). Children's Well-Being and Involvement in Physically Active Outdoors Play in a Norwegian Kindergarten: Playful Sharing of Physical Experiences. Child Care in Practice, 21(4), 305-323.

https://doi.org/10.1080/13575279.2015.1051512

- Ciolan, L., Nedelcu, A., Ulrich-Hygum, C., \& Iucu, R.(2019). Shaping the Research Puzzle in an Intervention Project. In M.H. Hoveid, L. Ciolan, A. Paseka \& S. Marques da Silva (Eds.), Doing Educational Research. Overcoming Challenges in Practice (pp.249-268). Sage.

- Comisia Europeană. (2019). Eurobarometru - Cum construim o Europă mai puternică, mai unită? Opiniile tinerilor. Flash 478.

https://ec.europa.eu/commfrontoffice/publicopinion/index.cfm/survey/ getsurveydetail/instru ments/flash/surveyky/2224

- Institutul Na ional de Sănătate Publică (INSP). Evaluare stării de bine a copilului in şcoală 2017-2019. https://insp.gov.ro/sites/cnepss/wp-content/uploads/ 2014/12/Sinteza-stare-de-bine-in-scoala-2019.pdf

- International Baccalaureate Organization (IBO). (2021). What is well-being?. Policy Research Paper.

https://ibo.org/globalassets/publications/ib-research/policy/what-is-well-beingeng.pdf

- Konu, A., \& Rimpelä, M. (2002). Well-being in schools: a conceptual model. Health Promotion International, 17(1), 79-87. https://doi.org/10.1093/heapro/17.1.79

- Kwi-Ok, N., Bjørgen, K., Go., Y.M., \& Yoo, Y.E. (2020). A comparative study of ECEC practitioners' perceptions of children's well-being and their roles in South Korea and Norway. European Early Childhood Education Research Journal, 28(6), 847-863. https://doi.org/10.1080/1350293X.2020.1836585 
- Lewis, A. (2019). Examining the concept of well-being and early childhood: Adopting multi-disciplinary perspectives. Journal of Early Childhood Research, 17(4), 294-308. https://doi.org/10.1177/1476718X19860553

- Marineanu, V. (2013). Mecanisme psihologice de influen are a atitudinilor. Editura Militară.

- Mashford-Scott, A., Church, A., \& Tayler, C. (2012). Seeking children's perspectives on their wellbeing in early childhood settings. International Journal of Early Childhood, 44(3), 231-247. https://doi.org/10.1007/s13158-012-0069-7

- Na iunile Unite. (2018). Raportul privind obiectivele de dezvoltare durabilă 2018. Editura Na iunilor Unite. https://unstats.un.org/sdgs/files/report/2018/ TheSustainableDevelopmentGoalsReport2018-EN.pdf

- Nedelcu, A., Ulrich-Hyngum, C., Ciolan, L., \& ibu, F. (2018). Educa ie cu stare de bine. După o re etă româno-daneză. https://rodawell.fpse.unibuc.ro/wp-content/uploads/2019/04/RODAWELL.pdf

- OECD. (2019). PISA 2018 Assessment and Analytical Framework. OECD Publishing. https://doi.org/10.1787/b25efab8-en

- OECD. (2019b). OECD Future of Education and Skills 2030 Conceptual learning framework - Learning compass 2030. OECD Publishing. https://www.oecd.org/education/2030-project/teaching-and-learning/learning/ learning-compass-2030/OECD_Learning_Compass_2030_concept_note.pdf

- OECD. (2012). Rezultatele testului PISA. OECD Publishing. http://www.oecd.org/pisa/keyfindings/pisa-2012-results.htm

- Pollard, E.L., \& Lee, P.D. (2003). Child Well-Being: A Systematic Review of the Literature. Social Indicators Research, 61(1), 59-78. https://doi.org/10.1023/A:1021284215801

- Raghavan, R., \& Alexandrova, A. (2015). Toward a theory of child well-being. Social Indicators Research, 121, 887-902. https://doi.org/10.1007/s11205-014-0665-z

- Rodawell. (2019). Instrument de autoevaluare. https://rodawell.fpse.unibuc.ro/instrument-de-autoevaluare/

- Rodawell. (2019). Starea de bine. https://rodawell.fpse.unibuc.ro/modelul-rodawell/starea-de-bine/

- Sapsağlam, Ö. , Bakkaloğlu, A.B., \& Eryýlmaz, A. (2019). The Scale of Happiness Strategies for Childrens Used by Preschool Teachers. Journal of Computer and Education Research, 7(13), 171-182. https://doi.org/10.18009/jcer.535593

- Seligman, M.E.P. (2011). Flourish: A visionary new understanding of happiness and well-being. Free Press.

- Sönmez, S., \& Ceylan, B. (2016). Teachers' perceptions of well-being and involvement in preschool children. Early Child Development and Care, 187(1), 35-44. https://doi.org/10.1080/03004430.2016.1150272 
- Statham, J., \& Chase, E. (2010). Childhood Wellbeing: A Brief Overview. Childhood Wellbeing Research Centre. https://citeseerx.ist.psu.edu/viewdoc/ download?doi=10.1.1.453.9199\&rep=rep1\&type=pdf

- Williams-Brown, Z., \& Mander, S. (2020). Childhood Well-being and Resilience: Influences on Educational Outcomes. Routledge.

The online version of this article can be found at: http://revped.ise.ro/category/2021-en/

\section{(Cc) $\mathrm{BY}-\mathrm{NC}-\mathrm{SA}$}

This work is licensed under the Creative Commons Attribution-NonCommercial-ShareAlike 4.0 International License.

To view a copy of this license, visit http://creativecommons.org/licenses/by-nc-sa/4.0/ or send a letter to Creative Commons,

PO Box 1866, Mountain View, CA 94042, USA.
Versiunea online a acestui articol poate fi găsită la: http://revped.ise.ro/category/2021-ro/

\section{(cc) BY-NC- $\overline{A A}$}

Această lucrare este licen iată sub Creative Commons Attribution-NonCommercial-ShareAlike 4.0 International License.

Pentru a vedea o copie a acestei licen e, vizita $i$ http://creativecommons.org/licenses/by-nc-sa/4.0/ sau trimite i o scrisoare către Creative Commons, PO Box 1866, Mountain View, CA 94042, SUA. 



\title{
ONLINE SCHOOLING IN RURAL AREAS IN ROMANIA DURING THE PANDEMIC: TEACHERS' PERSPECTIVES
}

\section{Cristina Tunegaru*}

\author{
University of Bucharest, \\ Faculty of Psychology and Educational Sciences, \\ Bucharest, Romania \\ cristina.tunegaru@gmail.com
}

\begin{abstract}
Because of the threat of the Coronavirus pandemic, schooling in Romania moved in distance regime in March 2020. During the next school year, each municipality chose the scenario for each school - face-to-face schooling or online learning - according to the local number of infections. However, online education encountered many difficulties in terms of material and human resources, especially in rural areas. In this study we aim to explore rural teachers' perspectives about online schooling in Romania, during the Coronavirus pandemic. The data - obtained through a series of interviews and questionnaires - were collected from rural teachers working in various parts of the country.

In this study we propose to follow two main directions. First, we explore teachers' experiences concerning the access to material resources in the school and at home. The absence of proper digital equipment and the quality of the internet connection are two of the main concerns for policy makers. Second, the study focuses on educational practice, discussing teachers' accounts and experiences during two periods: March-June 2020 and the next school year, until present. We intend to explore rural teachers' experiences in depth, as rural was always disadvantaged in Romania's education system. This study is a starting point for further research of rural teachers' preparedness in Romania and the implications of online learning on rural teachers and students.
\end{abstract}

* PhD. Candidate, Faculty of Psychology and Educational Sciences, University of Bucharest, Bucharest, Romania. 
Keywords: online schooling, pandemic, rural, teachers' experiences.

\section{Rezumat}

Din cauza amenin ării pandemiei de Coronavirus, şcolarizarea în România s-a mutat în regim la distan ă, în martie 2020. În anul şcolar următor, autorită ile din fiecare jude au ales scenariul pentru fiecare scoală - scoală online sau fa ă în fa $\breve{a}$-în func ie de numărul de infectări la nivel local. Educa ia online a întâmpinat însă multe dificultă $i$ în ceea ce priveşte resursele materiale şi umane, în special în zonele rurale. În acest studiu ne propunem să explorăm perspectivele profesorilor din mediul rural despre scolarizarea online din România, în timpul pandemiei de Coronavirus. Datele - ob inute prin interviuri şi chestionare - au fost colectate de la profesori din mediul rural care lucrează în diferite păr $i$ ale ării.

In acest studiu ne propunem să urmărim două direc ii principale. În primul rând, explorăm experien ele profesorilor cu privire la accesul la dotările necesare la şcoală şi acasă. Absen a unui echipament digital adecvat şi calitatea conexiunii la internet sunt două dintre principalele preocupări pentru deciden ii de politici publice. In al doilea rând, studiul se concentrează pe practica educa ională, discutând experien ele profesorilor în cele două perioade: martie-iunie 2020 şi anul şcolar următor, până în prezent. Ne propunem să explorăm în profunzime experien ele profesorilor din mediul rural, deoarece mediul rural a fost intotdeauna dezavantajat în sistemul de învă ământ din România. Acest studiu este un punct de plecare pentru cercetări ulterioare privind pregătirea profesorilor din România şi implica iile învă ării la distan ă asupra profesorilor şi elevilor din mediul rural.

Cuvinte-cheie: experien ele profesorilor, pandemie, rural, şcoala online.

\section{Introduction}

Information technology has had a growing impact in education for the last decades and the concept of online education enjoyed sustained academic interest. Basilaia and Kvavadze (2020) define online education as any learning activity where "information technology and communications are used to help in the development and acquisition of knowledge from the different remote locations. It uses the internet and video/audio and text communication and software to create the learning environment" (p. 1).

Basilaia and Kvavadze (2020) further recognize several types of online 
learning: knowledgebase ("a set of lessons that are published on a website and have general instructions for learning that a student has to follow, with no support available"); online support ("a modified version of the knowledge base where the support is available so there is a discussion board, web forum or another communication way available to get support"); asynchronous training ("the lessons do not take place in real time, but the students are provided with content regularly"; support is given "through email or other communication platforms"); synchronous training ("done in real time with a live instructor and optional moderator"; "participants can communicate directly with the teacher and other group members"); hybrid training ("a combination of online and in-person interaction").

In this article we explore online schooling solely through the Romanian experience during the pandemic which is characterized by improvisation and haphazard measures aiming to replace traditional interactions, which were unexpectedly curtailed. For most rural schools this experience is composed of two periods. The first period is marked by a sense of insecurity, fear in the social reality of the pandemic. School closed at the beginning of the pandemic (March 2020), and there was little interest for developing an online approach to education during that specific school year, though certain attempts were made by teachers and policy makers. Soon after March 2020, some teachers started to organize distance learning sessions using the knowledge they previously had. By the end of the school year 2019-2020, only students who needed to pass national examinations returned to school in special conditions. By the beginning of the next school year, the online schooling context changed dramatically, as the majority of schools/municipalities in Romania had to organize some form of online classes, accordingly to the scenario they were assigned: hybrid or online. Education policy makers scrambled to supply digital equipment for disadvantaged students.

These periods lack a systematic approach to create a cohesive online learning infrastructure. Rather we see a simple transposition from the traditional regime to the virtual one using the same strategies and teaching methods. Exploring teacher's experiences of online teaching, Truzoli et al. (2021) show that "depression and stress are the main predictors of satisfaction level for online teaching" and "coping, locus of control and self-efficacy emerge as important protective factors". 
Kim and Asbury (2020) show that strong relationship between teachers and a sense of community in the school are essential in overcoming uncertainty. Their study explores teachers' experiences during the first five weeks of online teaching caused by the pandemic and it highlights teachers' worries about vulnerable students and the need for "more joined-up thinking from the government", "along with clarity from policy makers".

In this study we explore rural teacher's experiences in the two periods discussed, focusing on the access to digital equipment for students and teachers and on teacher's practice during the online classes, their perceptions, and accounts regarding online teaching. We focus on rural school mainly for two reasons. First, because rural education was always disadvantaged in comparison to urban education, due to high rates of poverty, teacher mobility, staff turnover, poor school infrastructure, school dropout (Horga et al., 2017; Merce et al., 2015). In rural areas, $30 \%$ of households lack internet access, and the service cost constitutes a significant financial disincentive for disadvantaged families (INSSE, 2020). For the 2019-2020 academic year, the dropout rate for rural middle schools stood at $1.9 \%$, significantly higher than $0.8 \%$ for urban schools; for primary schools the rural dropout rate was $1.7 \%$ (INSSE, 2021). The high rates of poverty and early school leaving in recent history can explain the educational success of the parents: rural parents graduate an average of 9.74 years of school and just $0.7 \%$ finish a form of higher education, versus 12.1 years and $18 \%$ for urban parents. (World Vision, 2020). Although several public policies target rural education in Romania (Ungureanu, 2018), reducing inequalities between rural and urban continues to be a challenge, as rural is "a disadvantaged environment" (Stanef \& Manole, 2013). Second, Romania is among the countries with high shares of the rural population at European level (Eurostat, 2021). Thus, concentrating on rural population, seen as a vulnerable group, is a necessary action especially during the pandemic.

\section{Methodology}

The survey conducted collected information through the use of interviews and questionnaires with teachers working in rural schools during the COVID-19 Pandemic. Teachers were approached via email or social 
networks, the only criteria of interest being teaching experience in a rural school during the reference period. The interviews took place via Skype, Zoom or phone, as agreed with each teacher and lasted approximately an hour. The interviews, which consisted of open-ended questions, were recorded, then transcribed.

We employed two tools of data collection - interview and questionnaire. In total we collected 18 interviews and 12 questionnaires. Initially the teachers in the sample were invited to interviews, however some on the teachers who expressed their interest about the research preferred a questionnaire. Therefore, by analyzing the interviews in the sample, a questionnaire was created and sent to the remaining 12 teachers. The interviews and the questionnaires focused on: their teaching experience during the pandemic, the level of support they enjoyed from the school and authorities, whether they had adequate material support, connectivity, etc. and skill development for online teaching, the students' attendance and methods to reach them outside online education, the involvement of the parents, the learning gaps the teachers observed among the students upon return to school and whether they will continue to use online teaching methods after the pandemic restrictions are lifted.

The questionnaire survey and the interviews were conducted from May 2021 to June 2021. The questionnaires were sent by email. Before they answered the questionnaire, participants were offered adequate information about the study, its objectives, and the processing of the data. Moreover, all participants have given their informed consent for the participation and the processing of the data for research purpose.

A first pass over the raw interview data was performed to collect salient issues. These were identified based on the author's experience with online teaching and relevant topics from the literature. This process may be prone to systematic bias. In a second reading, the data was coded in the themes previously identified.

We identified the following themes:

(a) Access to digital resources in school and at home.

(b) Internet connection difficulties and improper equipment. 
(c) The presence of poverty.

(d) Online schooling methods.

(e) Teachers' perceptions about parental involvement in the pandemic context.

(f) Students' motivation and participation in online classes.

(g) Learning gaps occurred due to the new configuration of schooling.

\subsection{Sample}

The sample consists of 30 teachers working in rural schools across the country. They were selected from a large body of rural teachers who were approached online and invited to take part in the research. In total, approximately 200 invitations were sent. The resulting sample is random and no attempt was made to correct for geographical overrepresentation of certain counties. There was no previous contact with any participant. Every teacher in the sample represents a different school.

Table no. 1 outlines the professional profile of the resulting sample: number of teaching years, number of rural teaching years, the subjects they teach, the county.

Table no. 1. Professional profile of rural teachers in the sample

\begin{tabular}{|c|c|c|c|c|}
\hline Teacher & $\begin{array}{c}\text { Total no. of } \\
\text { teaching } \\
\text { years }\end{array}$ & $\begin{array}{c}\text { No. of years in } \\
\text { the rural } \\
\text { school }\end{array}$ & Subject & County \\
\hline AN & 20 & 20 & $\begin{array}{c}\text { Primary school } \\
\text { teacher }\end{array}$ & Constan a \\
\hline AP & 6 & 5 & $\begin{array}{c}\text { Primary school } \\
\text { teacher }\end{array}$ & Maramureş \\
\hline CG & 10 & 10 & $\begin{array}{c}\text { Romanian } \\
\text { Language }\end{array}$ & Vaslui \\
\hline VC & 11 & 11 & $\begin{array}{l}\text { Romanian } \\
\text { Language }\end{array}$ & Suceava \\
\hline MAO & 2 & 2 & $\begin{array}{l}\text { Romanian } \\
\text { Language }\end{array}$ & Vâlcea \\
\hline MD & 2 & 10 & $\begin{array}{l}\text { Romanian } \\
\text { Language }\end{array}$ & Neam \\
\hline BV & 25 & $\begin{array}{l}\text { Romanian } \\
\text { Language }\end{array}$ & Iaşi \\
\hline
\end{tabular}




\begin{tabular}{|c|c|c|c|c|}
\hline Teacher & $\begin{array}{c}\text { Total no. of } \\
\text { teaching } \\
\text { years }\end{array}$ & $\begin{array}{c}\text { No. of years in } \\
\text { the rural } \\
\text { school }\end{array}$ & Subject & County \\
\hline DA & 34 & 34 & $\begin{array}{l}\text { Romanian } \\
\text { Language }\end{array}$ & Ialomi a \\
\hline $\mathrm{CZ}$ & 14 & 14 & $\begin{array}{l}\text { Romanian } \\
\text { Language }\end{array}$ & Buzău \\
\hline MT & 10 & 10 & $\begin{array}{l}\text { Romanian } \\
\text { Language; } \\
\text { English }\end{array}$ & Vaslui \\
\hline SM & 2 & 1 & $\begin{array}{l}\text { Romanian } \\
\text { Language; } \\
\text { English }\end{array}$ & Prahova \\
\hline LMI & 1 & 1 & $\begin{array}{c}\text { Romanian } \\
\text { Language; } \\
\text { French }\end{array}$ & Buzău \\
\hline $\mathrm{PP}$ & 3 & 1 & Informatics & Bacău \\
\hline $\mathrm{AL}$ & 5 & 4 & Mathematics & Dâmbovi a \\
\hline $\mathrm{AB}$ & 12 & 12 & Mathematics & Tulcea \\
\hline $\mathrm{CD}$ & 15 & 10 & Mathematics & Mureş \\
\hline TR & 35 & 35 & Mathematics & Teleorman \\
\hline $\mathrm{MG}$ & 6 & 6 & French & Vaslui \\
\hline MV & 19 & 14 & French & Olt \\
\hline IU & 24 & 20 & French & Giurgiu \\
\hline $\mathrm{MN}$ & 4 & 4 & French & Bacău \\
\hline GA & 9 & 9 & French & Olt \\
\hline $\mathrm{ZC}$ & 23 & 23 & English & Gala i \\
\hline $\mathrm{OB}$ & 27 & 20 & English & Tulcea \\
\hline MM & 2 & 2 & History & Giurgiu \\
\hline $\mathrm{CM}$ & 12 & 10 & History & Bacău \\
\hline $\mathrm{PO}$ & 3 & 3 & Geography & Neam \\
\hline RE & 15 & 10 & $\begin{array}{l}\text { Geography; } \\
\text { Sports }\end{array}$ & Iaşi \\
\hline $\mathrm{EF}$ & 4 & 2 & Counselor & Suceava \\
\hline $\mathrm{CB}$ & 36 & 20 & Science & Dolj \\
\hline
\end{tabular}

In addition, to describe the sample, we explored the remoteness of each rural school. The distance from the teacher's home to school is extremely important in a rural educational context, as schools can be more or less desirable for teachers. The further from the city, the more remote the school is considered. The table below illustrates the distance from home to school for the teachers in the sample. We did not request or recorded objective 
distance data such as distance in kilometers from home to school, duration of commute, etc. Rather we used subjective self-assessment because teachers understand and perceive distance differently, considering some objective criteria, as access to public transportation, access to important roads and motorways, etc. This information was considered relevant because proximity to the school can have an impact on teachers' motivation, their relationship with the local community and colleagues and a long commute is a strong incentive to prefer online schooling to face to face teaching.

Table no. 2. Distance from school to home

\begin{tabular}{|l|c|c|}
\hline & No. of teachers & Percentage \\
\hline Living in the village & 8 & $26 \%$ \\
\hline Living in the city close to the village & 16 & $53 \%$ \\
\hline Far from school & 6 & $21 \%$ \\
\hline
\end{tabular}

Finally, as seen in the table below, we have explored teachers' connection with the rural environment.

Table no. 3. Teachers' connection with the rural environment

\begin{tabular}{|l|c|c|}
\hline & No. of teachers & Percentage \\
\hline Have lived in a rural environment & 15 & $50 \%$ \\
\hline Live in a rural setting & 7 & $26 \%$ \\
\hline Never lived in a rural setting & 8 & $24 \%$ \\
\hline
\end{tabular}

\subsection{Limitations}

One main limitation is the size of the sample and its random nature. Also, some counties are not represented while others are overrepresented.

This study took place at the end of the second school year affected by the pandemic - 2020-2021 - when each school in Romania followed a particular path according to the infection rate in the locality and the changes this rate suffered. Some schools spend more time than others following the online scenario. Some rural schools experienced the hybrid system as defined in 
the Introduction, while others didn't. Given these factors, each school experienced this period differently. This study explores teacher's experiences beyond the particularities of the school scenarios. We do not take into consideration the time each school spent in the online or hybrid system.

\subsection{Objectives}

The aims of this study are: (1) to explore rural teacher's access to digital equipment; (2) to highlight the positive and negative experiences of rural teachers during the pandemic focusing on educational practice; (3) to underline rural teacher's needs in the context of digitalizing education; (4) to give voice to teachers to express their personal and professional challenges they faced during the COVID-19 pandemic.

\section{Results}

3.1. Access to digital resources in school and at home

One of the main concerns of online schooling is the absence of proper equipment for schools, students, and teachers. In order to ensure access to education for all children, national and local strategies were implemented during the 2020-2021 school year. The ministry of education has allocated nationwide 250000 devices with internet connection to children from disadvantaged backgrounds.

However, in this study, teachers complain about the quality of the ministry's equipment for various reasons. Some report the difficulties encountered by using them: "we received those wonderful tablets, which really were not good quality, and made our work very difficult after that. When the child who received that tablet from the ministry was connected, well, I wanted to involve him/her. In response, it created a terrible howling, whistles, grunts, woes and a fantastic noise and it was terrible from this point of view." (AP, Primary school teacher). 
Other teachers report that the tablets arrived too late and were of poor quality and were difficult to use: "The school obtained 312 tablets through the "Home School" program, but they came too late, they broke down very quickly." (CM, History Teacher, Bacău).

Some teachers dispute the usefulness of these equipment, arguing that very disadvantaged students aren't able to use them until the family has access to utilities: "they received equipment, but they don't have electricity at home, or they don't have internet and the internet on the tablet doesn't work" (MM, History teacher).

Local efforts and campaigns may respond better to children's educational needs. As it can be seen in the account below, the social context of the village can have a powerful impact on schooling during critical periods. In one village in Vaslui, the priest is an important figure in children's education, finding and implementing local solutions, so that every student can participate in online classes: "Most of the children had [tablets], because we asked the priest for help. In our village, there was a small campaign to collect functional, but no longer used, tablets or phones and they were given to the children. Also, the priest, topped-up prepaid phone cards every month [...]" (CG, Romanian language teacher, Vaslui). The priest acted not only as an educational liaison for the community, but he organized a special room in the church's courtyard where students could borrow tablets and use them to connect during online classes: "Others [students] were able to go to a place near the church, a larger room with tables and chairs. The priest installed a router and children who had no signal or no equipment, took some tablets left by the priest and connected from time to time". In this particular approach, the school and the priest worked together to encourage and support students. This Romanian language teacher reports that most of the students were able to participate in online classes due to the conjugate efforts of the teachers, priest and the community as a whole.

Teachers argue that many students in rural schools needed to use a phone to connect to classes, even though this equipment is not adequate. "It's difficult on the phone, it's tiny" reports one primary school teacher, who states that, in her class, just 10 students could afford a tablet or a laptop while the other 17 children could only use the phone. Some students claimed they are not allowed to use a phone of a parent to connect to online classes. As a consequence, one Informatics 
teacher $(\mathrm{AB})$ declares that at some point "2-3 students were present at the online class. Teach Informatics to them online! But with what? Even those who log on have just a pitiful phone to watch. It's terrible."

\subsection{The quality of the internet connection}

We have found that the great majority of teachers consider that the quality of the internet connection was rather poor in rural localities and became a source of inequalities: "Some children really weren't malicious, they just couldn't connect because they didn't have a signal" (CG, Vaslui). Internet connection difficulties were encountered even in urban contexts. MG, a French teacher shares that "even in my city I had bad days with almost no connection, but for example in the village of V., in January, there was none at all, the children had to deal with mobile data, if they could afford it; if they didn't, they could not participate". Access to online education was limited for some students due to lack of adequate internet connections. Thus, the families were required to spend on mobile data fees.

The internet connection was disturbed or absent for different reasons, as the following: the area is in a process of modernization and expansion of the cable network $(\mathrm{MN})$, a specific phone network has no coverage in the village (EF, school counselor; CM, History teacher, PO, Geography; IU, French language), teachers experience loss of connections at mid-day, disturbances (MV, French teacher; DA, Romanian language).

\subsection{Online classes and poverty}

Online teaching in rural communities poses specific challenges for students and teachers, given the poverty, deprivation and internal immigration. According to national statistics data, in "rural localities over half of the population is at risk of poverty or social exclusion" (Andrei, 2018). Furthermore, "the likelihood that a person in rural areas will be in such a situation is twice as big, compared to a person from the urban environment; $29 \%$ of the population from rural areas in Romania lives in conditions of absolute poverty" (ibidem). The deprivation is not only reflected in access 
to digital equipment but also in habitation conditions. Teachers report that many children live in overcrowded homes in which it is impossible to assure silence and privacy for each child during online classes. A Romanian language teacher specifies that, during the pandemic, even 3-4 children needed to stay in the same room during the winter and take part in online classes at the same time: "when you want to listen to your student, you also hear the younger brother as his teacher listens to him" (CG). This instance poses specific challenges both for the teachers and the students, the access to quality online education is limited for these students. To summarize, living conditions can profoundly impact education and children's participation and attainment during online classes.

Moreover, the participation in online classes can be affected by farming activities, especially in very poor villages. EF, a school counselor, reports that since the beginning of February 2021, children started to participate more in household activities at the expense of online schooling: "they went on the tractor, they plowed, it didn't matter they were in the $6^{\text {th }}$ or $7^{\text {th }}$ grade". Some older students in high schools and vocational schools transitioned to jobs and other remunerated activities: "when school went online, they left to work abroad. They simply went to work to make money, which is their main goal. They still connected from time to time because their teachers threatened to expel them, but there were many absences, hundreds of absences. I also know cases of children who worked there, locally, at the flower shop, at the hairdresser's, to make money".

3.4. Online schooling methods and the traditional school environment

Because the transition to online classes was sudden and unexpected, many teachers found themselves little prepared to create and organize suitable activities and strategies. Their previous digital skills, their creativity and their ability to learn and reinvent were put to the test.

The first period of online classes (March-June 2020) is described as full of enthusiasm, effervescence for students who participate in sharing their knowledge with the teachers. ZC, English teacher, reports that she is happy because her students helped her in understanding some computer "secrets". While some teachers report that they have had no help and support from 
school, local community or educational institutions, experiencing a form of abandonment (AN: "I participated in training courses on my own initiative and on my own money, I taught the lessons from home"), others claim they could rely on themselves or their colleagues (RE: "I taught myself; when I didn't know I asked my colleagues. We helped each other all the time"; DA: "Within the school, we collaborate very well, it's the school family. I was always in touch with my colleagues, for any problem and at any time.") or the principal (DA: "the principal made accounts for students and teachers on the Google Classroom"; PO: "A guide on access to the platform was developed, both for students and teachers"). Some teachers report that local authorities helped the school with digital resources and connectivity, while others complain they were left to their own devices.

Some teachers attempted to transfer traditional methods and strategies to online classes, by using, for example, white boards or computer graphic tablets: "I used a mini-board on which I explained the lessons as if it were a class board" (LMI, Romanian Language teacher); "all I needed was a graphics tablet and an internet connection" (CZ, Romanian Language); "I paid for a graphics tablet with my own money first, then my school bought one." (AB, Informatics). Others were creative in order to keep students engaged and attentive: "I came up with new things, with innovations and, you realize, that math class on the internet is one thing and drawing class is something else. And I went with interactive games, with things that would attract them" (EF, school counselor).

However, the majority of teachers think they will continue to use and integrate in traditional teaching some form of online activity, because they are easy to use $(\mathrm{MG})$ or because of the diversity of online resources.

\subsection{Parental involvement}

Parents played an important role in online classes and teachers recognize the need of more intense parental involvement during the pandemic. While many teachers in this study complain of lack of control over students' involvement, the responsibility of supervision during online school shifted towards parents and family. Although the size of the sample does not allow us to make generalizable inferences, the interviewed teachers report that 
primary school parents appear more involved, continually talking and interacting with the teacher so that students are present and they complete school activities they are assigned. To point, AN, a primary school teacher confesses of being proud of her work with preparatory class (6-year-old students) because "they learned to read and to write, which were my objectives". Furthermore, she adds: "with those who did not manage to connect today, tomorrow, the day after, I spoke on the phone, or the parents often came to me: "Miss, I'm coming to town because I have shopping to do". "Okay, let's give you another activity sheet, let me explain you what I did, so that you can show it to your child at home" (AN, Primary school teacher).

However, a plurality of middle school teachers in the sample (MG, French teacher; LMI, Romanian teacher; MM, History teacher; PO, Geography) report that while some parents were involved in the students' school life during the pandemic, many parents were absent. The words "lack of interest" is used by the majority of teachers when talking about some parents. MV, a French teacher reports that "Most of the parents seem involved. I had online meetings with them, but only the parents who came to school also attended online meetings; but other parents said relaxed that it was no problem that the child did not attend online classes, it was because he/she was sleeping, or he/she was tired!". Further, MV shows that some parents have a different understanding and perception about education than teachers and a common ground is difficult to establish: "some parents have the impression that, if they start contradictory discussions, endless and full of reproaches to the school and to the teachers in general, on the class groups, they are involved and interested in education!"

\subsection{Students' motivation and participation in online classes}

Motivation is a key issue in education and especially in online schooling. Teachers in the sample report that initially students expressed enthusiasm to learn and interact via internet, but these reactions quickly vanished and made room for weariness, boredom. EF, a school counselor, analyzes the two periods saying that "by the end of February [2021] they were so bored with movies, power point slides, absolutely everything that means an online lesson, that it was very difficult to motivate them to participate". 
In her study of learning in an online environment, Wong (2020) identifies two basic learning needs that are not compatible with online schooling: relatedness "an individual's desire and need to connect and create a bondage with people" (p. 2) and arousal - "the state of learners engaged in an activity" with "positive arousal enabling continuous effort and participation in learning (p. 2).

Students turning their camera off and limiting their interaction with their peers are expressions many teachers encountered "In the class where I am a teacher, I told them "Guys, turn on that camera so everybody can see you, you are not watching TV" and one of them said to me, "I listened to you like the radio, Miss" (AB, Informatics). This attitude is not only a manifestation of tiredness, but it can also have psychological consequences, children learning from home may experience isolation, loss of contact with peers, thus being sensitive for behavioral changes, isolation, anxiety and depression (Deolmi \& Pisani, 2020). However, as Dvorsky et al. (2020) argue, "some youth who experience peer victimization likely find time away from school allows for greater concentration on academics, in addition to improved one-on-one interactions with peers and family, and unexpected social connections".

Turning their cameras off is understood by teachers as signs of formally participating in the lesson, students losing the relatedness and the arousal: "They weren't turning on the camera and they weren't answering when called by name either. I could see they were connected, but they didn't answer." (EF, school counselor); "although the students did not have their cameras on, it was obvious that some were doing something else but attending class, and others appeared connected but never responded when called" (MV, French teacher).

\subsection{Learning gaps}

When speaking about the learning gaps students face when returning to traditional schooling, teachers concentrate on two directions: 1. loss of essential competences, abilities and skills in writing, reading-comprehension, calculus, a slowdown in thinking; 2 . loss or change of social and interactional skills and abilities. The table below illustrates the teacher's evaluations of the students' development. 
Table no. 4. Teacher's evaluations of the students' development

\begin{tabular}{|c|c|c|}
\hline & No. of teachers & Percentage \\
\hline Indubitable learning and behavioral gaps & 12 & $40 \%$ \\
\hline Some learning and/or behavioral gaps & 7 & $23 \%$ \\
\hline Stagnation & 9 & $30 \%$ \\
\hline Progress & 2 & $7 \%$ \\
\hline
\end{tabular}

One Romanian Language teacher (VC, Suceava) expresses her concerns for the lack of proper writing guidance, which puts at risk certain vulnerable age group students: "It seems to me that a lot has been lost for spelling. We have transmitted the information [to students], but because I could no longer see a notebook, I could no longer make a personal correction, show the students where they need to correct something, a lot has been lost."

Students which transitioned from primary to middle school during the pandemic may be more at risk in losing key stages in the development of reading and writing skills: "Especially for students in the 5th grade who went online when they were in the 4th grade, I notice some grammar mistakes that I don't know how I will be able to fix. Good students, I'm not talking about the weak ones, good students who get 9 and 10 [maximum marks]. So, they make some mistakes... Maybe [online schooling is] for older students, which already... but for the little ones there are gaps and, unfortunately, it is for the worse (VC, Romanian teacher).

When returning to traditional schooling, many teachers report they needed to teach again the same lesson taught online: "I even mentioned [to them]: "we did the subject, I don't know if you remember". And it really was obvious that they didn't know, last year the communication at that time was like this ... an exchange of messages on WhatsApp" (VC, Romanian teacher). When talking about the online classes of the second period (2020-2021 school year), one teacher (CG) uses the phrase "unnecessary energy consumption", explaining that the majority of the students were present online, but very few of them were present with their spirit. 
Some learning gaps are due to the students' non-participation in online classes, while others are generated and are bound to the particularities of the school subject, especially when students are faced with a new subject, they may find it difficult to understand and integrate new concepts and knowledge in the context on online interactions with the teacher: "Personally, I believe students lost a great deal, especially the 5 th grade students. For them this was the first year of study for the modern language II. A foreign language is learned by repeating the words, by the teacher correcting the deficient pronunciation, by songs and poems adapted to the theme of the lesson and to the students' age, by explaining several times grammar issues totally different from those of the Romanian language." (MN, French teacher).

Behavioral changes and fear for other people's reaction are reported by EF, school counselor: "they lost the ability to have a conversation, to socialize. I had children who apologized for sneezing and I said "why do you apologize?". It's something physiological, something tickled your nose, it doesn't necessarily mean that ... The children were so scared that they would be kicked out of class coughing or sneezing, these poor people abstained as much as they could." Some students, especially from vulnerable groups estranged themselves from school and, as some teachers report "those who missed online school continued not to come to school or to come episodically. They participated in some classes but not in other" (EF, school counselor).

\section{Discussion and conclusions}

In this study we explore rural teachers' experiences concerning online education during the two periods (March-June 2020; September 2020-June 2021). The study employs in-depths interviews and questionnaire and explores the following themes: (a) access to digital equipment; (b) internet connection; (c) the impact of poverty; (d) online schooling methods; (e) parental involvement; (f) students' motivation; (g) learning gaps. The research found that teachers' experiences were very diverse. Some teachers worry about the negative educational, emotional and behavioral impact online education may have on younger or vulnerable students. They recognize the importance of authentic interactions between students and students and teacher, many advocating for returning to traditional schooling. 
A general theme that can be observed is that there exists a fundamental disconnect between intent and potential of online learning and the teaching practice. Teachers try to replicate traditional interactions using online communication tools which does not respond to students learning needs, especially arousal and relatedness. Most teachers seldom use appropriate teaching methods adapted to the online medium, they lack the appropriate guidance and are not aware that they need it, while the students lack of engagement is justified as bad faith.

Online schooling in rural localities encountered difficulties related to the development of the educational system in Romania, school infrastructure, as well as teachers' preparedness for online classes. Many teachers in the sample report that schools were not adequately prepared for online schooling. Rural school ought to be properly equipped with both the digital and technological infrastructure in order to sustain online classes when they are required. Moreover, a functional internet connection is required in every rural school, including in remote areas, so that online classes are accessible to every student, regardless of their residence.

On the one hand, we have uncovered systemic difficulties for online schooling. They are related to digital resources, school infrastructure, internet connection in school and at home and poverty. On the other hand, there are difficulties attributable to teachers' preparedness for online schooling, as parental involvement in education, online teaching methods, students' motivation and learning gaps.

A concerning problem which emerges from the study is the risk that students who failed to acquire basic competences, such as writing and readingcomprehension, during the haphazard deployment of online learning in Romania, will continue to be affected throughout their academic life. Identifying and correcting such outcomes is of critical importance for policy makers.

Conversely, a positive development is that the majority of teachers developed skills which enable them to use and incorporate digital resources in face-to-face classes. 
Given the contested impact of central educational decisions during the pandemic, we consider that local, community interventions should be encouraged in order to assure that vulnerable groups can participate in education. Additional staff and resources are needed in many rural localities.

\section{References}

- Andrei, T. (coord.). (2018). România: un secol de istorie: date statistice. Editura Institutului $\mathrm{Na}$ ional de Statistică.

- Basilaia, G., \& Kvavadze, D. (2020). Transition to Online Education in Schools during a SARS-CoV-2 Coronavirus (COVID-19) Pandemic in Georgia. Pedagogical Research, 5(4), 1-9. https://doi.org/10.29333/pr/7937

- Deolmi, M., \& Pisani, F. (2020). Psychological and psychiatric impact of COVID19 pandemic among children and adolescents. Acta bio-medica: Atenei Parmensis, 91(4), 1-5. https://doi.org/10.23750/abm.v91i4.10870

- Dvorsky, M.R., Breaux, R., \& Becker, S.P. (2020). Finding ordinary magic in extraordinary times: child and adolescent resilience during the COVID-19 pandemic. European Child \& Adolescent Psychiatry, 30, 1829-1831.

https://doi.org/10.1007/s00787-020-01583-8

- Eurostat. (2021, September 6). Eurostat Statistics on rural areas in the EU. http://ec.europa.eu/eurostat/statistics-explained/index.php/Statistics_ on_rural_areas_in_the_EU

- Horga, I., Jigău, M., Apostu, O., Fartuşnic, C., \& Costache, L. (2017). La şcoală: o privire asupra participării la educa ie folosind analiza pe cohortă. Alpha MDN.

- INSSE. (2020). Population access to information and communication technology - Romania. https://insse.ro/cms/sites/default/files/field/publicatii/accesul_ populatiei_la_tehnologia_informatiei_si_comunicatiilor_romania_2020_0.pdf

- INSSE. (2021). The educational system in Romania - synthetic data. School/ university year 2019-2020. https://insse.ro/cms/sites/default/files/field/ publicatii/sistemul_educational_in_romania_2019_2020.pdf

- Kim, L.E., \& Asbury, K. (2021). "Like a rug had been pulled from under you": The impact of COVID-19 on teachers in England during the first six weeks of the UK lockdown. British Journal of Educational Psychology, 90(4), 1062-1083. https://doi.org/10.1111/bjep.12381

- Merce, I.I., Milin, I., Petroman, C., \& Ciolac, R.M. (2015). School Dropout - A Social Problem in Romania. Procedia - Social and Behavioral Sciences, 182, 623-628.

- Stanef, R.M., \& Manole, A.M. (2013). Educational System Gaps in Romania. Procedia - Social and Behavioral Sciences, 93, 794-798. 
- Truzoli, R., Pirola, V., \& Conte, S. (2021). The impact of risk and protective factors on online teaching experience in high school Italian teachers during the COVID19 pandemic. Journal of Computer Assisted Learning, 37(4), 940-952. https://doi.org/10.1111/jcal.12533

- Ungureanu, E. (2018). An analysis of educational policy measures for rural education. Revista de Pedagogie, 66(2), 103-126. https://doi.org/10.26755/RevPed/2018.2/103

- Wong, R. (2020). When no one can go to school: does online learning meet students' basic learning needs?. Interactive Learning Environments. https://doi.org/10.1080/10494820.2020.1789672

- World Vision Romania. (2020). - Cursa celor 30 de ani de educa ie în România rurală. https://worldvision.ro/wp-content/uploads/2021/06/Sumar-studiu.pdf

The online version of this article can be found at: http://revped.ise.ro/category/2021-en/

\section{$(c))$ BY-NC-SA}

This work is licensed under the Creative Commons Attribution-NonCommercial-ShareAlike 4.0 International License.

To view a copy of this license, visit http://creativecommons.org/licenses/by-nc-sa/4.0/ or send a letter to Creative Commons, PO Box 1866, Mountain View, CA 94042, USA.
Versiunea online a acestui articol poate fi găsită la: http://revped.ise.ro/category/2021-ro/

\section{$( c c ) \longdiv { e r - n e - z a }$}

Această lucrare este licen iată sub Creative Commons Attribution-NonCommercial-ShareAlike 4.0 International License.

Pentru a vedea o copie a acestei licen e, vizita $i$ http://creativecommons.org/licenses/by-nc-sa/4.0/ sau trimite i o scrisoare către Creative Commons, PO Box 1866, Mountain View, CA 94042, SUA. 
SPERAN A FARCA, DESPRE FRICA DE NECUNOSCUT. Bucureşti, Editura Universitară, 2020, 266 pagini, ISBN 978-606-28-1167-9

\section{Oana Gheorghe*}

Universitatea Na ională de Arte, Departamentul pentru Pregătirea Personalului Didactic,

Bucureşti, România

oana.gheorghe@unarte.org

Cartea „Despre frica de necunoscut” este tratată din perspectiva multitudinii de roluri ale autoarei Speran a Farca, cele de psihanalist specializat în rela ia mamă-copil, de pedagog, de cercetător în ştiin ele educa iei, de cadru didactic universitar şi, nu în ultimul rând, din perspectiva rolului de mamă. Ca şi în publica iile precedente, autoarea a reuşit să abordeze aspecte relevante asupra cărora părin ii, psihologii, educatorii, consilierii şcolari şi chiar medicii pot reflecta atunci când se confruntă cu probleme frecvente sau mai pu in frecvente întâlnite atât în dezvoltarea copilului, cât şi în propria dezvoltare.

Cartea „Despre frica de necunoscut” este prima dintr-o serie care tratează subiectul fricii de necunoscut. Cel de-al doilea volum al seriei, ,Leacuri pentru frica de necunoscut", analizează şi dezvăluie diferite cauze ale fricilor, precum şi posibile mecanisme de apărare. Cele două căr i se completează una pe cealaltă, dacă prima identifică şi explică diferite tipuri de frici, cea de-a doua carte oferă cititorilor explica ii şi solu ii pentru toate aceste frici.

Principala temă a căr ii „Despre frica de necunoscut” este, aşa cum se subîn elege din titlu, necunoscutul şi teama de acesta, unul dintre factorii care pot influen a dezvoltarea şi evolu ia copilului. Încă din primele pagini ale căr ii sunt prezentate principalele teme care urmează a fi dezvoltate astfel încât să ajute cititorii să în eleagă de ce uneori se simt ,nesiguri şi agresivi, intoleran i şi rigizi”, care este sensul etichetării, ce îi face să devină

* Lector universitar doctor, Departamentul pentru Pregătirea Personalului Didactic, Universitatea Na ională de Arte, Bucureşti, România. 
prevăzători, să râdă în hohote, să se joace sau să-şi dezvolte sim ul umorului. Din cele cinci capitole ale acesteia, Cum apare spaima de necunoscut, Mama şi necunoscutul, Cine este necunoscutul, Simbolicul - construc ie generată de spaima de necunoscut, Mecanisme de apărare specifice spaimei de necunoscut, aflăm că este în regulă să avem temeri, scăpări sau să greşim; că un părinte/ copil nu trebuie să fie perfect sau să corespundă anumitor tipare prestabilite (de exemplu, Patul lui Procust, ,Pare mai simplu să găsim o sursă autorizată care să ne ajute să nu mai bâjbâim în decizii, care să ne dea iluzia siguran ei. Dar o sursă externă nu are cum să ni se potrivească total. Riscul este ca tocmai astfel să instalăm, fără voie, un pat al lui Procust după care să ne ghidăm.” pag. 30). Cartea ne provoacă să conştientizăm şi să în elegem mai bine propriile frici, să ne acceptăm neputin ele şi defectele pentru a putea deveni mai toleran i fa ă de noi înşine şi, implicit fa ă de ceilal i. De asemenea, prin intermediul căr ii, autoarea atrage din nou aten ia asupra importan ei creării unui mediu asigurator nu numai pentru nou născu i, ci şi pentru adolescen i, care să le permită să se dezvolte, să evolueze, să se descopere. Astfel, teama de necunoscut este prezentată ca o etapă firească, ,naturală” a dezvoltării noastre, ca o modalitate prin care ne putem în elege ,pe noi la diferite vârste şi putem să le fim alături copiilor noştri mici şi adolescen i”.

Laitmotivul lucrărilor sale este regăsit şi în cartea de fa ă. Astfel, mama este prezentată ca ,,principalul intermediar între lume, necunoscut şi copil.” Aceasta înso eşte copilul şi îl ajută, prin exemplul personal să se dezvolte emo ional. Alături de mama sa, copilul înva ă despre consecven $\breve{a}$ - mama cunoscută şi anticipabilă îl face pe copil să se simtă în siguran ă să exploreze şi să fie curios fa ă de lumea din exterior. „O mamă consecventă nu se lasă descifrată doar pe sine, ea îşi ajută copilul să în eleagă lumea din jur. Dacă îi explică emo ional lumea, aceasta îi devine inteligibilă copilului.”' (pag. 21). Înva ă despre consisten $\breve{a}$, mama fiind cea care are aptitudinea de a răspunde ,grabnic şi adecvat trebuin elor” copilului, ,,de a distinge între nevoile şi dorin ele" acestuia.

O altă învă ătură primită de copil de la mama sa este despre flexibilitate, în eleasă ca abilitatea mamei de a ,,vibra afectiv adecvat cu mediul din jur, cu nevoile copilului şi cu ale sale." (pag. 24). Speran a Farca atrage aten ia asupra importan ei adaptării mamei la fiecare situa ie în parte, a urmării 
instinctelor proprii, în defavoarea abordării perceptelor ,exper ilor momentului" în materie de parenting. Lecturarea căr ii ne face să ne conştientizăm propriile limite şi, mai important, să în elegem că aceste limite sunt fireşti şi că rolul de mamă/ părinte nu presupune să faci totul perfect, fără de greşeală. Ajungem, astfel, la următoarea învă ătură, cea despre responsabilitate. În percep ia autoarei, doar o mamă relaxată ,,poate fi capabilă să-şi asume responsabilitatea maternită ii, care presupune dedicare în condi ii de libertate" (pag. 25). Relaxarea nu este în eleasă ca neimplicare sau dezinteres, ci ca o împăcare a mamei cu deciziile luate în privin a ocrotirii şi îngrijirii copilului, ca o eliberare de vinovă ie.

Tot alături de mama sa, copilul înva ă despre disponibilitate, despre acceptarea şi despre primirea de sprijin, indiferent de context. „Copilul are nevoie să-i fim alături şi atunci când nu în elegem ce e cu el. Când nu-l aprobăm şi când suntem nesigure şi nelămurite.” (pag. 28). Nu în ultimul rând, încrederea ,se înva ă” tot prin intermediul ac iunilor şi atitudinilor mamei.

Şi în cartea de fa ă, autoarea atrage aten ia asupra unor hibe împământenite ale şcolii, ,Şcoala nu are răbdare cu copiii, grăbeşte procesul de cunoaştere, iar pentru a-i spori eficien a, apelează la concentrare. Concentrarea înso ită de pasiune necesită mult timp şi dedicare, iar teama este un instrument la îndemână pentru focusare.” (pag. 76), propunând, totodată o abordare adaptată nevoilor fiecărui copil în parte în cazul tuturor situa iilor ivite: „,Deci e simplu, e suficient ca şcoala să fie un mediu sigur, în care oamenii să poată experimenta curioşi şi curajoşi. Să eliminăm frica de greşeală, de batjocura celorlal i, de abuzuri de tot felul. Într-un astfel de mediu, nimeni nu este mai bun decât altul căci fiecare este preocupat să-şi descopere şi să-şi dezvolte propriile abilită i. De succesul cuiva ar trebui să se bucure toată lumea, fiindcă orice descoperire ne ajută pe to i." (pag. 80).

Este interesant modul în care necunoscutul este analizat ca neştiin ă, ca tot ceea ce este în afara corpului propriu sau ca noi înşine, în diferite etape ale dezvoltării umane (copilărie, adolescen ă), când toate schimbările din noi şi din jur ne transformă. În cel de-al treilea capitol al căr ii, autoarea încearcă să identifice ,necunoscutul”, să-l aducă mai aproape de cititor sau să-l determine pe acesta să-şi identifice propriile necunoscute. Doar identificarea 
necunoscutului poate duce la identificarea măsurilor care să ne ajute să facem fa ă spaimelor, asigurându-ne, astfel, un demers terapeutic. Acest demers autoanalitic este foarte bine eviden iat/ surprins în ideea: ,,Străinul este necunoscutul din jurul nostru, dar mai ales ceea ce nu acceptăm la noi. Aproapele nostru este chiar străinul care ne oglindeşte. Rela ia pe care o stabilim cu acesta arată felul în care ne raportăm la noi înşine.” (pag. 262). Sunt prezentate solu ii, explica ii şi exemple ale modurilor în care diferite categorii de persoane gestionează sau îşi înfruntă fricile de necunoscut în via a lor de zi cu zi. Astfel, ultimul capitol al acestei căr i este o anticipare a căr ii „Leacuri pentru frica de necunoscut”, în care autoarea ,explică” fricile pe în elesul cititorului, în elegerea acestora fiind necesară în vederea unei mai bune cunoaşteri de sine şi a consolidării rela iilor sociale.

Cartea clarifică cititorului diferite stări sau reac ii personale, îl ajută să se în eleagă mai bine pe sine şi pe ceilal i. În paginile acesteia, autoarea îndrumă, oferă exemple, descrie tehnici şi metode opera ionale, făcând constant şi firesc trecerea de la abordarea teoretică la cea practică pentru o mai bună în elegere a diferitelor probleme sau solu ii prezentate. Aşa cum ne-a obişnuit în publica iile sale, Speran a Farca ajută cititorul să în eleagă mai bine subiectele abordate prin intermediul unor exemple relevante extrase din poveşti, basme, nuvele, mituri sau legende, dar şi prin exemple personale sau profesionale. Nu în ultimul rând, nu putem să nu admirăm uşurin a cu care autoarea trece de la un subiect la altul şi mai ales firul narativ cursiv. Astfel, subiectele ,curg” firesc şi natural, precum o poveste, făcând lectura uşoară, plăcută şi mai ales revelatoare.

The online version of this article can be found at: http://revped.ise.ro/category/2021-en/

\section{(c) EY-ne-sa}

This work is licensed under the Creative Commons Attribution-NonCommercial-ShareAlike 4.0 International License.

To view a copy of this license, visit http://creativecommons.org/licenses/by-nc-sa/4.0/ or send a letter to Creative Commons, PO Box 1866, Mountain View, CA 94042, USA.
Versiunea online a acestui articol poate fi găsită la: http://revped.ise.ro/category/2021-ro/

\section{$(\mathrm{Cc}) \overline{\mathrm{B}-\mathrm{NC}-\mathrm{sA}}$}

Această lucrare este licen iată sub Creative Commons Attribution-NonCommercial-ShareAlike 4.0 International License.

Pentru a vedea o copie a acestei licen e, vizita $i$ http://creativecommons.org/licenses/by-nc-sa/4.0/ sau trimite i o scrisoare către Creative Commons, PO Box 1866, Mountain View, CA 94042, SUA. 
IONALBULESCUŞI HORA IU CATALANO, e-DIDACTICA. PROCESULDE INSTRUIRE ÎN MEDIUL ONLINE. Bucureşti, Editura Didactica Publishing House, 2021, 416 pagini, ISBN 978-606-048-366-3

\title{
Gina-Florentina Tudorache*
}

\author{
Şcoala Gimnazială ,,Mihai Eminescu”, \\ Ploieşti, România \\ gina.tudorache16@yahoo.com
}

Mihaela Badea*

Universitatea Petrol-Gaze,

Departamentul pentru Pregătirea Personalului Didactic,

Ploieşti, România

mbadea@upg-ploiesti.ro

Revolu ia digitală aduce schimbări însemnate în toate sectoarele de activitate, facilitând desfăşurarea oricărui proces ce stă la baza atingerii elului propus. Pentru aceasta, folosirea eficientă a noilor tehnologii ale informa iilor şi comunica iilor reprezintă cheia de boltă a oricărui demers desăvârşit.

Utilizarea tot mai accentuată a noilor tehnologii digitale, sus inută în ultima perioadă de pandemia de Coronavirus, are reverbera ii inclusiv în plan educa ional, mutând procesul didactic în mediul online. Această mişcare socială fără precedent a adus multiple transformări procesului instructiv-educativ în planul formatului de livrare a con inutului, în planul spa iului de predare-învă are, al accesului la informa ie şi, implicit, al abordărilor didactice. Aşadar, luăm parte la avansarea serviciilor educa ionale şi la constituirea unor comunită i virtuale de învă are, ceea ce suscită redimensionări didactice pentru ca educa ia să răspundă în consonan ă cu cerin ele curente de formare a tinerei genera ii.

* Profesor învă ământ primar doctor, Şcoala Gimnazială „Mihai Eminescu” Ploieşti; profesor asociat, Departamentul pentru Pregătirea Personalulului Didactic, Universitatea Petrol-Gaze, Ploieşti (Prahova), România.

** Conferen iar universitar doctor, Departamentul pentru Pregătirea Personalului Didactic, Universitatea Petrol-Gaze, Ploieşti (Prahova), România. 
În fa a intensită ii noilor tehnologii digitale, profesorul, ca actor principal al evolu iei educa ionale, are nevoie de o redimensionare a didacticii tradi ionale care să-l sprijine în utilizarea şi gestionarea eficientă a multitudinii de device-uri şi materiale digitale. În acest sens, prezenta lucrare pune la dispozi ia dascălilor însemnate repere teoretice şi practice care să îi ghideze atât în dezvoltarea competen elor digitale, cât şi în optimizarea practicilor educa ionale implementate în mediul online.

Fiind structurată în douăsprezece capitole, cartea prezintă un cadru aprofundat al procesului de învă ământ ce necesită a fi adaptat erei digitale, plecând de la „e-Learning şi Blended Learning în societatea informa ională”. Cele două concepte reprezintă formele învă ării online introduse de dinamica educa ională sub influen a noilor tehnologii, unde: e-Learning înglobează toate situa iile educa ionale online (sincron sau asincron) în care mijloacele TIC sunt folosite ca bază în procesul de predare-învă are-evaluare sau în procesul de comunicare; Blended Learning sau învă area mixtă combină situa iile de învă are desfăşurate fa ă în fa ă în interiorul sălii de clasă cu situa iile de învă are online. Profilarea acestor dimensiuni de învă are generate de era digitală suscită revizuirea abordărilor pedagogice în concordan ă cu exigen ele societă ii informa ionale, conturându-se o nouă didactică, Didactica 3.0., care expune mişcarea reformatoare a procesului instructiv-educativ în concordan ă cu evolu ia socială şi condi iile prezente de via ă.

Capitolul II, „Competen ele digitale ale profesorilor”, prezintă detaliat cunoştin ele, abilită ile şi atitudinile necesare dascălilor pentru a folosi eficient întreg ansamblul de materiale şi mijloace digitale în proiectarea, dezvoltarea şi implementarea instruirii, astfel încât să creeze experien e educa ionale semnificative. Astfel, este conturată o gamă extinsă de competen e elementare care vizează şase arii de manifestare: folosirea TIC în interac iunea cu to i actorii implica i în procesul educa ional, dar şi în dezvoltarea profesională; utilizarea creativă a resurselor digitale pentru instruire; utilizarea echilibrată a resurselor digitale în predare şi învă are; folosirea strategiilor digitale în procesul evaluării; alegerea mijloacelor TIC care să poten eze strategiile didactice centrate pe elev; competen e pedagogice care să faciliteze dezvoltarea competen ei digitale a elevilor.

Capitolul III, „Curriculum şcolar: managenentul con inuturilor în spa iul virtual. 
Situa ii şi experien e de învă are online”, profilează parametrii con inutului de tip virtual astfel încât acesta să reprezinte o bază în formarea competen elor ce determină profilul de formare al elevului. De asemenea, pe lângă ilustrarea unei liste generoase cu cele mai bune instrumente de învă are în mediul virtual, prezintă modalită i eficiente de gestionare a con inuturilor curriculare de tip virtual în diverse formate de instruire (fa ă în fa ă, e-Learning sincron şi asincron, Blended Learning).

Capitolul IV, „,Designul strategiilor didactice din perspectiva instruirii online”, aduce în aten ie provocările, oportunită ile şi limitele instruirii în mediul virtual, dincolo de multitudinea demersurilor de a crea experien e de învă are online pline de însemnătate. Totodată, în această fază ascendentă de utilizare a mijloacelor şi resurselor digitale, capitolul subliniază necesitatea implementării Didacticii 3.0., o abordare socio-constructivistă a procesului de învă ământ, conturând clar rolul profesorului şi al elevului în această interac iune didactică. De asemenea, este prezentată o serie de recomandări pentru selectarea celor mai adecvate strategii de instruire online în vederea optimizării şi eficientizării procesului instructiv-educativ, eviden iindu-se poten ialul jocurilor digitale în abordarea personalizată a stilurilor de învă are ale elevilor, cât şi în formarea priceperilor şi deprinderilor în mod autonom.

Capitolul V, „Învă area colaborativă online”, descrie explicit deosebirea dintre învă area colaborativă şi învă area cooperativă, prezentând avantajele, principiile de realizare ale acestora, precum şi repere semnificative în proiectarea şi implementarea unor astfel de activită i desfăşurate în mediul online.

Capitolul VI, ,Conjunc ia teoriilor învă ării cu educa ia online: între metodologie şi tehnologie", prezintă implica iile teoriilor învă ării în procesul de învă ământ desfăşurat în mediul virtual şi schi ează o serie de principii pedagogice în vederea facilitării învă ării online, bazate pe ideologii cognitiviste, constructiviste şi socio-constructiviste. De asemenea, sunt descrise trei modele de hibriditate (intrinsec, mixt şi extrinsec) utilizate ca mijloace didactice în predarea şi învă area online, plecându-se de la reprezentarea explicită a arhitecturii platformelor specifice e-Learning.

Capitolul VII, „,̂nvă are şi design instruc ional online”, orientează aten ia asupra mecanismelor învă ării umane din perspectivă behavioristă, cognitivistă 
şi constructivistă, marcând impactul acestora asupra designului instruc ional online. Astfel, este schi ată o serie de recomandări privind accentuarea interac iunilor cu con inuturile, precum şi sprijinirea interac iunilor sociale care să asigure colaborarea actorilor educa ionali.

Capitolul VIII, „Utilizarea re elelor sociale în procesul de instruire online”, pune la dispozi ie sugestii pentru înglobarea re elelor sociale în predarea şi învă area online, astfel încât dascălii să poată transforma din social media un mijloc favorabil învă ării, dirijând eficient şi creativ timpul pe care elevii îl petrec pe aceste re ele.

Capitolul IX, „Metodica resurselor şi a instrumentelor digitale utilizate în procesul de instruire online", prezintă o gamă largă de platforme şi resurse educa ionale care sus in desfăşurarea procesului instructiv-educativ în mediul virtual. De asemenea, sunt subliniate repere importante de care dascălii trebuie să ină seama în alegerea corectă a resurselor digitale, în îmbinarea lor armonioasă, precum şi în utilizarea eficientă a acestora.

Capitolul X, „Evaluarea în contextul învă ământului universitar de tip online”, conturează dimensiunile acestei păr i inerente a procesului instructiv-educativ din perspectiva implementării sale în mediul virtual, prezintă o serie de principii ce condi ionează eficien a acestui proces desfăşurat online şi, de asemenea, exemplifică descriptori de performan ă pentru diverse tehnici, metode şi instrumente de evaluare online. Totodată, capitolul prezintă registrul competen elor digitale necesare evaluării de tip online astfel încât aceasta să se desfăşoare obiectiv şi fără tentative de fraudă.

Capitolul XI, ,Evaluarea în e-Learning”, subliniază premisele evaluării online în direc ia creşterii implicării şi motiva iei elevilor, impactul dimensiunilor sale asupra stresului, identificând posibile efecte pozitive asupra anxietă ii de evaluare. De asemenea, prezintă o serie de oportunită i pentru dezvoltarea abilită ilor de gândire pe care evaluarea din mediul de instruire online le poate oferi, punând la dispozi ie o varietate de instrumente utile pe care dascălii le pot folosi în crearea unor experien e concludente de evaluare.

Capitolul XII, „Comunitatea de învă are eTwinning”, oferă dascălilor o perspectivă de facilitare a comunicării şi colaborării cu ări europene şi non-europene pentru a fi la curent cu noile mişcări în educa ie. În acest 
sens, ultimul capitol al acestei lucrări prezintă dimensiunile acestui important program pentru educa ie şi formare, criteriile de evaluare a proiectelor din cadrul acestei comunită i, structura portofoliului eTwinning, condi iile de implicare în cadrul acestei comunită i, precum şi paşii necesari pentru crearea unui proiect eTwinning.

Urmărind impactul pe care criza socială adusă de epidemia cu virusul SARSCoV-21-a avut asupra procesului de învă ământ, lucrarea,,e-Didactica. Procesul de instruire în mediul online", coordonată de Ion Albulescu şi Hora iu Catalano, oferă dascălilor, într-o reprezentare extinsă, repere fundamentale de proiectare şi implementare eficientă a procesului instructiv-educativ în contextul învă ământului online. Împletirea armonioasă a abordărilor teoretice cu cele practic-aplicative conturează un cadru cu puternice valen e asupra perspectivelor şi strategiilor didactice ale profesorilor. În acest sens, pe baza analizei detaliate a dimensiunilor procesului de învă ământ aflat sub reverbera iile utilizării tot mai accentuate a noilor tehnologii, este profilată revizuirea abordărilor pedagogice în concordan ă cu era digitală, configurându-se o nouă didactică, Didactica 3.0. Valorificarea principiilor acestei mişcări novatoare declanşate în sistemul de învă ământ va sprijini eforturile cadrelor didactice de a crea în mediul online situa ii şi experien e de învă are pline de semnifica ie şi, de asemenea, de a gestiona eficient con inuturile în concordan ă cu diversele formate de instruire.

Aşadar, oferind repere general valabile în proiectarea şi implementarea procesul de instruire online, considerăm că această lucrare reprezintă un real sprijin în eficientizarea activită ii didactice pentru to i dascălii, indiferent de nivelul de învă ământ la care predau.

The online version of this article can be found at: http://revped.ise.ro/category/2021-en/

\section{(cc) $\mathrm{BY}-\mathrm{NC}-\mathrm{SA}$}

This work is licensed under the Creative Commons Attribution-NonCommercial-ShareAlike 4.0 International License.

To view a copy of this license, visit http://creativecommons.org/licenses/by-nc-sa/4.0/ or send a letter to Creative Commons, PO Box 1866, Mountain View, CA 94042, USA.
Versiunea online a acestui articol poate fi găsită la: http://revped.ise.ro/category/2021-ro/

\section{(cc) BV-NC-sA}

Această lucrare este licen iată sub Creative Commons Attribution-NonCommercial-ShareAlike 4.0 International License.

Pentru a vedea o copie a acestei licen e, vizita $i$ http://creativecommons.org/licenses/by-nc-sa/4.0/ sau trimite i o scrisoare către Creative Commons, PO Box 1866, Mountain View, CA 94042, SUA. 



\section{CEDEFOP, INVENTORY OF LIFELONG GUIDANCE SYSTEMS AND} PRACTICES - ROMANIA, CareersNet national records, 2020

\section{Angela Andrei*}

National Centre for Policy and Evaluation in Education,

Education Research Unit,

Bucharest, Romania

angelica.andrei@ise.ro

CareersNet is a professional network of experts in lifelong career guidance and career development, established in 2017 by the European Centre for the Development of Vocational Training (Cedefop).

CareersNet undertakes thematic research activities in the field of lifelong guidance and monitors policy developments and innovative practices in EU countries and in some European Economic Area (EEA), European Free Trade Association (EFTA), European Union (EU) accession countries. It includes experts from Austria, Belgium, Bulgaria, Cyprus, Denmark, Estonia, Finland, France, Germany, Greece, Hungary, Ireland, Italy, Luxembourg, Malta, Montenegro, Netherlands, Norway, Poland, Portugal, Romania, Serbia, Slovenia, Spain, Sweden, Turkey and the United Kingdom.

CareersNet provides access to harmonised, comparable evidence of relevant practices and promotes their transfer and adaptation; facilitates cross-national comparative analysis of national systems and initiatives; and supports countries in national policy development.

The inventories of lifelong guidance systems and practices of European countries (Cedefop, 2020b) are available on the website of Cedefop for interested practitioners, decision-makers and researchers across the world.

* Senior Researcher, PhD., Education Research Unit, National Centre for Policy and Evaluation in Education (CNPEE), Bucharest, Romania; CareersNet National Expert. 
Practitioners in career guidance have access to relevant European practices and opportunities for transfer and adaptation, peer learning and exchange of ideas on relevant topics such as: ICT use in career guidance or development of career management skills.

Decision-makers have the opportunity to consult information regarding the systems of career guidance in European countries and receive support and insights on national developments and the national relevance of EU initiatives.

Researchers in career guidance have access to cross-national comparative analysis of national guidance systems and initiatives.

The Inventory of lifelong guidance systems and practices - Romania (Cedefop, 2020a) offers insights on career development activities embedded in distinct policy fields, such as education, training, youth and labour market policy in Romania. It contains the following sections: Introduction, Coordination and collaboration among national, regional and local stakeholders, Access to guidance, Quality assurance, Career management skills, Evidence, monitoring and assessment of the effectiveness of career guidance, Career information and ICT in lifelong guidance, Training and qualifications, Funding career guidance, Career guidance for school pupils, Career guidance for vocational education and training (VET) participants, Career guidance for higher education students, Career guidance for the employed, Career guidance for unemployed adults, Career guidance for older adults, Career guidance for Early School Leavers (ESL), Career guidance for Not in education, employment or training (NEET) youth, Career guidance for immigrants and refugees.

In April 2020, CareersNet members contributed to content on how guidance services were adapting in the pandemic (Cedefop, 2020c). The network is involved in Cedefop's update of the 2009 Cedefop publication on professionalising career guidance in line with developments during the last ten years and the evolving digital context. This publication will be released at the end of 2021.

CareersNet plans to update the inventories of lifelong guidance in 2022 and to further develop country reviews using the inventory contents, in addition to a methodology for system assessment and evaluation. 


\section{References}

- Cedefop. (2009). Professionalising career guidance. Practitioner competences and qualification routes in Europe. Office for Official Publications of the European Communities.

- Cedefop. (2020a). Inventory of lifelong guidance systems and practices Romania. CareersNet national records.https://www.cedefop.europa.eu/en/ publications-and-resources/country-reports/inventory-lifelong-guidancesystems-and-practices-romania

- Cedefop. (2020b). Inventory of lifelong guidance systems and practices. CareersNet national records. https://www.cedefop.europa.eu/en/ publications-and-resources/country-reports/inventory-lifelong-guidancesystems-and-practices

- Cedefop. (2020c). Note on lifelong guidance and the COVID-19 pandemic: Responses from Cedefop's CareersNet. https://www.cedefop.europa.eu/files/ 2020_05_27_llg_and_pandemic_cnet_b.pdf

The online version of this article can be found at: http://revped.ise.ro/category/2021-en/

\section{(oc) EY-NG- $2 A$}

This work is licensed under the Creative Commons Attribution-NonCommercial-ShareAlike 4.0 International License.

To view a copy of this license, visit http://creativecommons.org/licenses/by-nc-sa/4.0/ or send a letter to Creative Commons, PO Box 1866, Mountain View, CA 94042, USA.
Versiunea online a acestui articol poate fi găsită la: http://revped.ise.ro/category/2021-ro/

\section{(cc) DY-NC-SA}

Această lucrare este licen iată sub Creative Commons Attribution-NonCommercial-ShareAlike 4.0 International License.

Pentru a vedea o copie a acestei licen e, vizita $i$ http://creativecommons.org/licenses/by-nc-sa/4.0/ sau trimite i o scrisoare către Creative Commons, PO Box 1866, Mountain View, CA 94042, SUA. 



\title{
INNOVATION IN CAREER GUIDANCE: INTERNATIONAL TRENDS AND CASE STUDIES
}

European Training Foundation

European Training Foundation,

Turin, Italy

Middle-East Technical University,

Fusun Akkok*

Ankara, Turkey

fusun@metu.edu.tr

Angela Andrei**

National Centre for Policy and Evaluation in Education,

Education Research Unit,

Bucharest, Romania

angelica.andrei@ise.ro

Florian Kadletz***

European Training Foundation,

Turin, Italy

florian.kadletz@etf.europa.eu

Hanna Voronina****

National Technical University of Ukraine "Igor Sikorsky Kyiv

Polytechnic Institute",

Kyiv, Ukraine

hannavoronina@ukr.net

Almira Zakiyeva*****

National Researcher,

Kazakhstan

almira.zakiyeva@gmail.com

\begin{abstract}
This paper is a summary of a report on innovative examples of policies, practices and research at international level, from the European Union, and from selected

* Emeritus Professor, the Middle-East Technical University, Ankara, Turkey.

** Senior Researcher, PhD in Education Sciences, Education Research Unit, National

Centre for Policy and Evaluation in Education (CNPEE), Bucharest, Romania.

***Specialist in Entrepreneurship and Enterprise Skills for the EU Agency European

Training Foundation, Turin, Italy.

**** Senior teacher, PhD in Education, the National Technical University of Ukraine "Igor Sikorsky Kyiv Polytechnic Institute", Kyiv, Ukraine.

***** National Researcher, Kazakhstan.
\end{abstract}


partner countries (Kazakhstan, Turkey and Ukraine) of the European Training Foundation, Turin, Italy. The report examines career guidance through the analysis of policies and practices, identified in the education and training systems as well as in the employment and social policies developed in different countries as a response to global challenges (e.g., advancement of technology, demographic and environmental changes, health crisis). Moreover, this report analyses the megatrends that career guidance currently faces, centering on the use of Information and Communication Technology (ICT), Career Management Skills (CMS) development, cooperation and coordination mechanisms used in career guidance, the parents' role in supporting their children's career choices.

As well, the paper presents innovative examples that focus on how career guidance has evolved in a constantly transforming world and labour market in order to support individuals to learn throughout life and to develop their competences in education, training and labour market contexts.

Keywords: career guidance, career management skills (CMS), cooperation and coordination mechanisms, information and communication technologies (ICT), role of parents.

\section{Rezumat}

Acest articol este rezumatul unui raport care prezintă exemple inovative de politici, practici şi cercetări din Uniunea Europeană (U.E.), de pe plan international şi din ările partenere ale Funda iei Europene de Formare, Torino, Italia, selectate pentru acest raport (Kazakstan, Turcia şi Ucraina). Raportul examinează consilierea şi orientarea carierei prin intermediul analizei unor politici şi practici identificate in sistemele de educa ie şi formare profesională, precum şi ale unor politici de ocupare a for ei de muncă şi sociale, ca răspuns la provocările globale (exp. evolu iile tehnologiei, schimbările demografice şi de mediu, criza sanitară). În plus, acest raport examinează mega-tendin ele cu care se confruntă în prezent consilierea şi orientarea carierei, axându-se pe utilizarea tehnologiilor informatice şi de comunicare (TIC), dezvoltarea competen elor de managementul carierei (CMC), mecanismele de cooperare şi coordonare utilizate în consilierea şi orientarea carierei, rolul părin ilor în sprijinirea alegerilor de carieră ale copiilor.

De asemenea, articolul prezintă exemple inovative care se focalizează asupra modului în care consilierea şi orientarea carierei evoluează într-o lume şi o pia ă a muncii care se transformă permanent, astfel încât să sprijine indivizii să înve e pe tot parcursul vie ii şi să îşi dezvolte competen ele în contexte de educa ie, formare şi ale pie ei muncii. 
Cuvinte-cheie: competen e de managementul carierei (CMC), consilierea şi orientarea carierei, mecanisme de cooperare şi coordonare, rolul părin ilor, tehnologii informatice şi de comunicare (TIC).

\section{Introduction}

The global developments (e.g., advancement of technology, demographic modifications, environmental deterioration, health crisis) have increased the challenges for education, training and the labour market systems. As a whole, this impact can be observed daily in the lives of individuals and in societies. In other words, the way individuals learn and work was influenced by the technological progress. An example of this transformation can be seen in the idea that a job for life is being replaced by constant change and uncertainty. In this sense, individuals are required on the one hand, to become lifelong learners, and on the other hand, they need to acquire new skills, adapt and shape their existing skills, in order to cope with the changes they face.

Therefore, this puts a challenge for more support for the individual and on the career guidance system in general. As a paradox, the career guidance system is already faced with its own challenges and shifts in developing the innovation capacity of career guidance services and achieving a broader impact. Yet, another equally important challenge refers to empowering the individuals to manage their own career paths.

Desk research combined with interviews and field visits were the foundations of the methodological approach of this report. The 48 innovative examples from the European Union and across the world were presented based on the information collected through desk research and analysis by the international expert. The 25 innovative examples from the ETF partner countries (Kazakhstan, Turkey and Ukraine) were selected and presented by three national experts through desk research and interview-based field work (September-November 2019). 


\section{Education and training systems, employment and social policies in the context of global challenges}

Societies have advanced in an increasing globalized world and the resulting new conditions have profoundly influenced the education, training and labour market systems and social policies as well as the individuals and the society as a whole. These new conditions have modified the skills required on the labour market and the ways in which individuals learn and work (European Training Foundation, 2020a).

The low-skilled workers are negatively influenced by these changes as they usually have poor career expectations and are in danger of becoming jobless (Cedefop, 2019). Since early 2020, the Covid-19 pandemic has generated a global health crisis and has increased the need of introducing technological solutions in the education institutions, workplaces and homes.

2.1. Responses to the global challenges in education and training reforms

Investing in education, vocational education and training (VET) and lifelong learning (LLL) represent the preconditions for strong economic development. In other words, enhanced policies are needed to improve the education systems, in order to better prepare youth for entering the labour market through aspects that relate to changes in school curricula, learning climate, teacher's competences, as well as, ensuring the transition between education and the labour market. These include targeted developments of adult learning, upskilling and reskilling. Two contextual aspects are important in this improvement of policies, the aging of the population and migration.

2.2. Responses to the global challenges in employment and social policies

With the aim to foster inclusive and viable long-term development and reduce poverty, specific programmes that promote skills improvement and social inclusion are all the more necessary through the involvement of employers. In addition, proactive strategies and a holistic approach are vital to ensure the cooperation of labour, health, social and psychological services. Our 
analysis showed that most of the countries have employment programmes targeted to specific groups containing career information, work choice, search and maintenance, skills-development activities, life-skills activities and support services. Moreover as a result, it is even more important to promote decent jobs for individuals, especially for aging, migrant, refugee and displaced workers.

The predictors that can influence employment policy and career guidance are sustainability in employment policy and adjustment to the climate changes. In this context, certain services, such as public employment services (PES) and PES professionals need to consider the increase of demands for skilled labour force (Borbély-Pecze, 2019). In this sense, the employment services have an important contribution to ensure these demands, while PES counsellors need to comprehend on the one hand, the needs of the clients and on the other hand, they should organise the services so as to support the individual's active involvement in the labour market transitions.

\subsection{Career guidance's role - innovation needed}

Career guidance approaches and practices should take into account the global challenges as well as aid both public policies and individuals in approaching those. In other words, it is crucial that the career guidance is integrated in various policies and strategies, e.g. lifelong learning (LLL) or social policy. As a consequence, this integration should be reflected in a qualitative career-development programmes provision and access for citizens to the services, while the strategically policy measures should be seen by stakeholders (governments) as ways to address inequalities, to increase the employment rates of high risk groups, as well as to support college and career readiness efforts (Solberg, 2017).

The focus for career-development programmes and services should be on helping individuals to improve their decision-making, proactive and resiliency skills instead of just helping them to make suitable career decisions (Solberg, 2017). In this context, the demand will be more on the role of career guidance, which means it has to adjust promptly and to be malleable to the dynamic demands of the individuals and the labour market. 
The practitioners should also be well-qualified to assume their mission of 'keeping hope alive and affirming the dignity of their clients' (Herr, 1997). The mission can be assumed by: helping young people in dealing with certain career confusion, working with diverse clients (disadvantaged youth, older workers, migrants, adults involved in new forms of work, etc.), implementing an individualised service provision, developing the sustainability approach, developing the transversal skills of the beneficiaries (for example, social and emotional skills) or increasingly using the Information and Communication Technology (ICT) in career guidance.

Providing career guidance for all categories of beneficiaries is challenging and especially in the case of migrants, ethnic minorities, low-skilled workers, individuals with a low socioeconomic status, NEETs, unemployed adults or people involved in new forms of work (platform work, self-employed, online work). Hence, at the same time, the need to become more diverse and tailored by different career-guidance services is acknowledged. Their aim will be to increase the employability of citizens and link them to the needs of the labour market (Arnkil et al., 2017). Thereby, having access to free careerguidance support is essential for disadvantaged groups.

Offering individualised career-guidance services and taking into consideration the actual life situations of the beneficiaries would help this process even more. In this sense, employers require support to better use the human capital of their staff, as well as to involve them in relevant career development activities (Cedefop, 2011). Employees can receive effective support in their career decisions and personal development through a better coordination between career guidance and the validation of non-formal and informal learning (Cedefop, 2019). Furthermore, a direct involvement of the employees in designing and developing career guidance activities will contribute to offering more effective and tailored services for them.

Another aspect that has become increasingly critical refers to the development of transversal skills (e.g, social and emotional skills and careermanagement skills), that should be developed through career guidance activities. According to European Commission Joint Research Centre (2019), the jobs that are better remunerated than others are the ones that require a combination of digital and transversal skills. 
Employees need effective social awareness skills to collaborate with their colleagues and employers and to deal with various work situations, as well as well-developed self-management skills to take part in lifelong learning activities. In consequence, the focus should be on social and emotional skills expansion: self-awareness, social awareness, self-management, relationship skills, and decision-making (CASEL, n.d.,) through educational and career guidance activities undertaken in various settings (education institutions, public employment services, companies, NGOs, etc.).

Career-management skills (CMS) are considered a category of skills which help an individual to manage his/her career in manners that are individually beneficial. Some of these CMS can be gained through learning, training and work experience in a lifelong process rather than in a single step (e.g. when opting for a career route) (Neary \& Dodd, 2016).

"Green guidance" is an innovative approach which concerns the sustainability aspect, as well as aspects related to environmental conscientiousness and responsibility for the ecosystem. In this sense, this kind of work and job choice deal with reducing environment harm and improving awareness of the value of green careers (Plant, 2014).

The Covid-19 pandemic and the following health crisis generated a new context for the field of career-guidance (Hooley, 2020). In this situation, the role of career-guidance counsellors, lies on supporting individuals to identify and implement solutions to this crisis. The clients, in this sense, should have access to other suitable services of mental-health or welfare support, being referred to them by qualified career-guidance professionals. More so, the importance of implementing ICT and artificial intelligence (AI) solutions in the field of career guidance was emphasized by the Covid-19 crisis. The role of digital technology is even more crucial and should be more reflected upon, not as a mere solution that permits the sustainability and continuance of services during such situation (pandemic) for the future of education and career guidance, but also for the personalization of learning and career guidance. 


\section{Mega-trends in career guidance and innovative examples in the $\mathrm{EU}$ and at the international level}

This article addresses the following mega-trends in career guidance: the use of ICT in career-guidance systems; career-management skills development; cooperation and coordination mechanisms between key stakeholders in career guidance, and the role of parents in young people's career choices. Furthermore, other emerging trends in the international debate have been identified and presented in the ETF report (2020a, 2020b): social justice as an issue in career guidance; bringing career guidance closer to communities; 'co-constructing' the careers of guidance counsellors; providing evidence and accountability of career-guidance practices; and the co-careering approach.

\subsection{Use of ICT in career-guidance systems}

The methods of learning about careers in the new contexts requires the use of open data and mobile devices like smartphones, apps, tablets and wearables (e.g., smart watches) (Attwell \& Hughes, 2019). In this sense, we can include the use of various ICT devices or apps that are known to most people such as audio or videotape tools (Clark, 2016), chatrooms and instant messaging (Nagel \& Anthony, 2016), forums (Carlson-Sabelli, 2016), or more specialist solutions, like massive open online courses (MOOCs) (Bakshi \& Goss, 2019). Anthony Watts expressed the idea of the "transformational potential of ICT" (e.g., Watts, 1986, 1996, 2010). ICT is seen in the literature as a tool, when ICT supplements the other tools that can be used in career guidance services; as an alternative, when it replaces ICT with other careerguidance services elements; and, as an agent of change, when ICT fundamentally modifies the structure of the career-guidance services (e.g., Watts, 1996, 2010, as cited in Kettunen, 2017).

Online career information and its sub-types include: digital and online career information systems (CIS), labour-market information (LMI) systems and web-based interactive systems in career guidance. The enabling of digital transformation was exploited and traded by big data via artificial intelligence (AI). Career guidance can use big data for analysing "real time" educational 
and labour-market information through online platforms with the purpose of supporting individuals in making career and training decisions. Nevertheless, in career guidance, the use of AI is a new and under-researched topic (Bright, 2015). The use of chatbots brings benefits in career guidance as they respond to repetitive and typical questions, as well as to improving the efficiency of a career-guidance service as they allow the practitioners to concentrate on the in-depth counselling and guidance of their beneficiaries. Other apps can use for instance, GPS abilities of mobile devices to offer local employment and training-opportunity information for clients. As well, they allow more time for the practitioner to deal with detailed aspects of career development. The use of career simulators with enhanced AI supports the development of appropriate risk-taking behavior related to career pathways (e.g., Bright, 2015; The Real Game, see Jarvis \& Keeley, 2003).

Offering effective distance career guidance and employment interventions and helping the beneficiaries to search for labour-market information (LMI) require innovative change of career-guidance approaches and practices as well as the transformation of the professional identity of career-guidance practitioners through relevant training and professional support (Bimrose \& Brown, 2019).

\subsection{Career-management skills}

The importance of career-management skills (CMS) development for citizens was brought up through two European Union Guidance Resolutions of the Council of the European Union (2004, 2008). CMS refer to "a range of competences which provide structured ways for individuals and groups to gather, analyse, synthesise and organise self, educational and occupational information, as well as the skills to make and implement decisions and transitions" (ELGPN, 2012). Another important document, European Key Competences for Lifelong Learning framework (European Council, 2018) introduced other key concepts such as 'personal, social and learning to learn competence', defined as 'the ability to reflect upon oneself, effectively manage time and information, work with others in a constructive way, remain resilient and manage one's own learning and career". This key competence 
contains components related to career-management skills. In this sense, countries are requested to identify what career management skills are the most important in their context and thus, integrate them into the education system and skills-development policies (ICCDPP, 2019).

The curriculum model is one of the most relevant modalities to teach careermanagement skills. CMS should be encompassed in school curricula at all education levels (primary, secondary, postsecondary, VET, higher education). The development of instruments for assessing CMS should also be undertaken simultaneously with the elaboration of a national CMS framework (ELGPN, 2015).

\subsection{Cooperation and coordination mechanisms in career guidance}

Across the world and in different countries, institutions in charge of career guidance, service providers and employers are requested to find better ways to work together effectively. The Council Guidance Resolution (2008), through Priority area 4, recommended an increasing of the coordination and cooperation among various national, regional and local stakeholders. The support of guidance policy cooperation in education and employment sectors between the Member States was ensured in the period 2007-2015 by the European Lifelong Guidance Policy Network (ELGPN). This EU-wide collaboration contributed to legislative and strategic measures, as well as to the establishment of national guidance policy forums in many countries.

The activity of the ELGPN is continued by CareersNet, Cedefop's network for lifelong guidance and career development, established in 2017, with the aim to provide access to harmonised, comparable evidence of relevant practices in countries, to advocate their transfer and adjustment; to facilitate cross-national comparative studies of national systems and initiatives; and to support countries in their national policy development (CareersNet Cedefop, n.d.).

Euroguidance is a European network of national resource and information centres for lifelong guidance. It encourages among others, cooperation among different stakeholders in lifelong guidance and education on the one hand, as well as offers support to the national and international networking of lifelong 
guidance practitioners, on the other hand (Euroguidance, n.d.). The International Centre for Career Development and Public Policy (ICCDPP) organizes international symposia as means to develop mechanisms to carry out the communication between career-guidance policy and practice.

\subsection{The parents' role in young people's career choices}

The engagement of parents in career guidance activities is an important topic which needs to be more researched. A Dutch study (Warps, 2013, as cited in Oomen, 2019) showed that, even in one-off, information-centred sessions, the involvement of parents in career education and guidance, can contribute to the growth of study success of Dutch students in the first year of higher education. Nevertheless, other evidence (Barnes et al., 2020) revealed that parental participation in career-guidance activities can be more aspirational than in a systematised or mandated pattern. In this sense, some countries have built specific policies for involving parents in the career decisionmaking of young people, but this implies a broader strategy, more often. These broad strategies refer to the aim of improving educational outcomes, preventing drop-out, supporting socially disadvantaged children, etc.

It is important for policy makers and practitioners to acknowledge the role of career-guidance in informal provisions, all the more when shaping or restructuring formal career-guidance services, especially when it is delivered by peers, the family (mostly parents) and by representatives of the broader community (relatives, friends, private tutors, authorities, people seen as successful models, etc.), where the concerned individuals live (Zelloth, 2009).

3.5. Examples of initiatives illustrating the mega-trends in career guidance

Below is a table that briefly presents selected initiatives for the four megatrends (ICT, CMS, cooperation and coordination, role of parents), based on information regarding their impact, while the ETF report includes a total number of 43 innovative international initiatives and 5 other emerging approaches with detailed descriptions. 
Table no. 1. Examples of initiatives illustrating the mega-trends in career guidance

\begin{tabular}{|c|c|c|c|}
\hline Type of initiative & Name & Country & Key features \\
\hline $\begin{array}{l}\text { Digital communication } \\
\text { apps }\end{array}$ & $\begin{array}{l}\text { eGuidance } \\
\text { (eVejledning) }\end{array}$ & Denmark & $\begin{array}{l}\text { It supports career } \\
\text { counselling delivery by } \\
\text { practitioners using } \\
\text { digital communication } \\
\text { means. It comprises } \\
\text { JobCity and My } \\
\text { Competence Portfolio } \\
\text { apps. }\end{array}$ \\
\hline $\begin{array}{l}\text { Competency } \\
\text { framework }\end{array}$ & $\begin{array}{l}\text { Careers Management } \\
\text { Skills (CMS) } \\
\text { Framework }\end{array}$ & Scotland & $\begin{array}{l}\text { It defines and describes } \\
\text { the career-management } \\
\text { skills under four themes } \\
\text { (self-competences, } \\
\text { strengths, horizons, } \\
\text { networks). It helps the } \\
\text { delivery of career- } \\
\text { guidance services in } \\
\text { different formats. }\end{array}$ \\
\hline $\begin{array}{l}\text { Integrated service } \\
\text { provision/Cooperation- } \\
\text { coordination }\end{array}$ & $\begin{array}{l}\text { One-Stop-Shop } \\
\text { Guidance Centres } \\
\text { (Ohjaamo) }\end{array}$ & Finland & $\begin{array}{l}\text { Private, public and } \\
\text { third-sector service } \\
\text { providers come together } \\
\text { in one centre to help } \\
\text { youth into work. }\end{array}$ \\
\hline $\begin{array}{l}\text { Programme in schools/ } \\
\text { Role of parents }\end{array}$ & $\begin{array}{l}\text { Bridging the dialogue } \\
\text { between parents and } \\
\text { children for career } \\
\text { counselling and } \\
\text { guidance }\end{array}$ & Pakistan & $\begin{array}{l}\text { It aims to support } \\
\text { parents in guiding their } \\
\text { children in career } \\
\text { education by offering } \\
\text { activities for parents in } \\
\text { schools (e.g. responding } \\
\text { to questionnaires, } \\
\text { taking part in dialogues } \\
\text { and participating in } \\
\text { workshops, etc.). }\end{array}$ \\
\hline
\end{tabular}

\section{Innovative examples from selected countries: evidence of international trends and areas for improvement}

In this section, we present a synthesis of the innovative ideas and examples from Kazakhstan, Ukraine and Turkey in relation to the international trends in career guidance and areas for improvement. Detailed descriptions of the innovative practices in career guidance, selected from many countries across 
the world are included in the European Training Foundation report (ETF, 2020b).

\subsection{Kazakhstan}

At the national level, through the Ministry of Labour and Social Protection (MLSP) and the Ministry of Education and Science (MoES), the governance of the career-guidance system is being ensured. Career guidance is put in practice by local government, PES (employment centres) and secondary schools at the regional and local levels. TVET organisations and universities are the supply side of education providers. The National Chamber of Entrepreneurs 'Atameken' (NCE) and its Regional Chambers of Entrepreneurs (RCE) represent the employers and labour-market actors. Information and access to local businesses, entrepreneurs and their workforce requirements are offered by NCE and RCEs.

Kazakhstan actively uses ICT such as web-based interactive systems, as well as big data in public service, education, employment and career-guidance activities. Regarding the digital ecosystem and teaching digital skills, especially in remote and rural areas of the country, there is a lot of work to be done to emphasise these topics, while the government is actively dealing with these challenges. The programme 'Digital Kazakhstan' was approved by the government of Kazakhstan and it is being implemented in 2018-2022.

The career management skills are acknowledged by employers, educational organisations and employment services as crucial to sustainable employment and employability. The career guidance practitioners and policy makers recognize the need of enhancement and streamlining of the coordination mechanisms in career-guidance. The role of parents, families and peers in making career choices is highlighted by career-guidance practitioners and policy makers, with the lack of a systemic informal career-guidance practice. Parents are engaged on an ad-hoc or urgent basis or when career-guidance activities require transmitting test outcomes that demand special attention or when parents themselves are actively interested in the process of career guidance. 


\subsection{Ukraine}

The Ministry of Economy and the State Employment Service Centres, the Ministry of Youth and Sports, the Ministry of Education and Science, the Ministry of Social Policy, NGOs, employer associations and private services are involved in the provision of career-guidance services. A Memorandum for Collaboration has been signed in 2019 to consolidate the efforts of all the related stakeholders for creating an effective system of public career guidance in Ukraine. Since 2019, under the initiative of the Ministry of Youth and Sports, youth centres have been established across the country.

The selected innovative practices illustrate the stakeholders' readiness for the further improvement of the career-guidance system. The ICT tools support the Ukrainian jobseekers to identify appropriate career options. The E-tool SmartJob provides motivating video courses, webinars, video-counselling and video $\mathrm{CV}$ builder for improving soft skills and facilitating a job search process.

Career Hub Ukraine regularly launches career information booklets and career lessons (Career Maps), organizes educational and career projects and competitions, develops methodologies for career counselling for young people in secondary schools, VET schools and universities to support building national strategies and action plans for youth.

A successful partnership of business, state and educational sectors for finding solutions for youth unemployment was initiated by the Ukrainian Pact for Youth-2020 through the National Action Plan, National Conferences and Forums. It involved representatives of international and local businesses, provided workplaces, career mentoring and cooperation programmes for young Ukrainians.

The City of Professions is a mobile career-oriented event which takes place yearly with the participation of children and their parents to learn about the world of occupations. Family Career Tree is another popular educational project for school children that brings a better understanding of family roots and is very important for career self-determination. 


\subsection{Turkey}

The Ministry of National Education (MoNE) and the Turkish Employment Agency ( ŞKUR) affiliated to the Ministry of Labour, Social Security and Family (MLSSF) offer most of the career-guidance services in various contexts: universities, the private sector, trade unions and employer associations. All these institutions have signed a Memorandum of Understanding which represents a foundation for the National Career Guidance Forum. Turkey's National Development Plans contain articles and sections on lifelong guidance for all age levels (Cedefop, 2021). Educational, career and personal/social guidance services are integrated in guidance and psychological counselling services in MoNE. In addition, in Turkey's 'Skills Vision 2020' road map, information guidance, counselling and work-based learning are acknowledged. Their contribution is highlighted in creating a socially cohesive, knowledge-based economy, reducing regional disparities and creating a proactive, entrepreneurial labour force in which young people and women can entirely take part. MoNE released its "2023 Education Vision" paper in November 2018 (Ministry of National Education Turkey, 2018), which introduces consistent revisions in the school curricula and in the system of guidance and counselling. These changes aim to empower the young people for the changing demands of the world of work of 2023. SKUR undertakes activities in schools and provides vocational training to unemployed people on employability skills: https://esube.iskur.gov.tr/kurs/kursOnAir.aspx? ProgrammeTur-1

Turkey is aware of the importance of ICT tools needed for individuals to access educational/training, labour-market and career information. Schools are establishing career offices to support the students, starting with the 9th grade for better self-understanding, self-exploration and awareness to build a career profile based on values, competences and interests. An important role in the socialisation process and in the children's development is played by the nuclear and extended families.

\section{Conclusions and recommendations}

The career guidance systems need to be context specific and the innovative examples included in the ETF report should stimulate reflection and offer 
inspiration for practitioners, decision makers and researchers. Research plays an important role to offer evidence-based information about the impact, as well as career-guidance service effectiveness. This is why decision makers should reflect and implement changes on these matters. Cooperation and collaboration at policy and practice level, a shift from support for making career and/or education choices at transition points towards enabling individuals to manage their own education and careers, a multi-channel approach to delivery, availability of quality labour-market information (LMI) for the use of individuals in their career development and by professionals in guidance provision, as well as professionalism and quality assurance of careerservice provision are just some of the key features overall for having an adequate understanding of career guidance for supporting individuals in the context of the 21st-century labour market and society (ETF, 2020a).

Future lessons that can be learned from this report refer to how career guidance could reflect the need to take into account a wider context of reflection from an economical, employment, social, youth, education and training-policy objectives. Nevertheless, for innovation and effective governance in career-guidance services to occur the following are needed: on the one hand, coherence and efficient partnerships among all the involved organisations and, on the other hand, adequate repartition of resources.

Modern infrastructure for developing and implementing career-guidance services by using different technology (e.g. career information systems, labour market information systems, web-based interactive systems, or integrating social media, apps and chatbots into career-guidance provision), requires decision makers to acknowledge the importance of technology and innovation for career-guidance in general.

\section{NOTES}

This article is a summary version of the report:

European Training Foundation (ETF) (2020a). International trends and innovation in career guidance. Volume I. Thematic chapters:

https://www.etf.europa.eu/sites/default/files/2020-11/innovation_in_career_ guidance_vol._1.pdf 
European Training Foundation (ETF) (2020b). International trends and innovation in career guidance. Volume II. Country case studies:

https://www.etf.europa.eu/sites/default/files/2020-11/innovation_in_career_ guidance_vol._2_0.pdf

\section{Contribution}

The manuscript was drafted by Prof. Fusun Akkok and finalised by Angela Andrei with the contribution of Florian Kadletz, Hanna Voronina and Almira Zakiyeva (in alphabetical order). They are all the authors of the European Training Foundation (ETF) report (2020a, 2020b), mentioned above.

\section{References}

- Arnkil, R., Spangar, T., \& Vuorinen, R. (2017). Practitioner's toolkit for PES building career guidance and lifelong learning. Publications Office of the European Union.

- Attwell, G., \& Hughes, D. (2019). Learning about Careers: Open data and Labour Market Intelligence. Revista Ibero-americana de Educación a Distancia (RIED), 21(2), 81-106. http://dx.doi.org/10.5944/ried.22.1.22289

- Bakshi, A.J., \& Goss, S. (2019). Trends related to ethics, technology, counselling and careers. British Journal of Guidance \& Counselling, 47(3), 265-273. https://doi.org/10.1080/03069885.2019.1630603

- Barnes, S.-A., Bimrose, J., Brown, A., Gough, J., \& Wright, S. (2020). The role of parents and carers in providing careers guidance and how they can be better supported. International evidence report. University of Warwick.

- Bimrose, J., \& Brown, A. (2019). Professional identity transformation: supporting career and employment practitioners at a distance. British Journal of Guidance \& Counselling, 47(6), 757-769. https://doi.org/10.1080/03069885.2019.1698008

- Borbély-Pecze, T. (2019). Prevention for active people: career guidance [Discussion paper]. PES Annual Mutual Learning Conference "How to prevent unemployment in a changing world of work?".

https://ec.europa.eu/social/BlobServlet?docId=20600\&langId=en

- Bright, J.E.H. (2015). If you go down to the woods today you are in for a big surprise: seeing the wood for the trees in online delivery of career guidance. British Journal of Guidance \& Counselling, 43(1), 24-35. https://doi.org/10.1080/03069885.2014.979760

- CareersNet Cedefop. (n.d.). Cedefop's expert network for lifelong guidance 
and career development. https://www.cedefop.europa.eu/en/events-andprojects/networks/careersnet

- Carlson-Sabelli, L. (2016). Using forums to enrich counsellor training and supervision. In S. Goss, K. Anthony, L.S. Stretch \& D.M. Nagel (Eds.), Technology in mental health: Applications in practice, supervision and training (2nd ed., pp. 248-259). CC Thomas.

- Collaborative for Academic, Social and Emotional Learning (CASEL). (n.d.). Fundamentals of SEL. https://casel.org/what-is-sel/

- Cedefop. (2011). Working and ageing. Guidance and counselling for mature learners. Publications Office of the European Union.

- Cedefop. (2019). Coordinating guidance and validation. Publications Office of the European Union.

- Cedefop. (2021). Inventory of lifelong guidance systems and practices Turkey. CareersNet national records. https://www.cedefop.europa.eu/en/ publications-and-resources/country-reports/inventory-lifelong-guidancesystems-and-practices-turkey

- Clark, G. (2016). Traditional uses of technology in counsellor training and supervision. In S. Goss, K. Anthony, L.S. Stretch \& D.M. Nagel (Eds.), Technology in mental health: Applications in practice, supervision and training (2nd ed., pp. 260-271). CC Thomas.

- Council of the European Union. (2004). Resolution of the Council on strengthening policies, systems and practices in the field of guidance throughout life in Europe.

http://ec.europa.eu/education/policies/2010/doc/resolution2004_en.pdf

- Council of the European Union. (2008). Resolution of the Council and of the Representatives of the Governments of the Member States, meeting within the Council of 21 November 2008 on better integrating lifelong guidance into lifelong learning strategies. Official Journal of the European Union.

- Euroguidance. (n.d.). Euroguidance Network. Linking Lifelong Guidance and International Mobility across Europe. https://www.euroguidance.eu/

- European Commission Joint Research Centre. (2019). The changing nature of work and skills in the digital age. Publications Office of the European Union. https://ec.europa.eu/jrc/en/publication/eur-scientific-and-technical-researchreports/changing-nature-work-and-skills-digital-age

- European Council. (2018). Council Recommendation of 22 May 2018 on Key Competences for Lifelong Learning, 2018/C 189/01-13. Brussels.

- European Lifelong Guidance Policy Network (ELGPN). (2012). Lifelong Guidance Policy Development: A European Resource Kit. Saarijärven Offset Oy Saarijärvi.

- European Lifelong Guidance Policy Network (ELGPN). (2015). Designing and Implementing Policies Related to Career Management Skills (CMS). Kariteam Jyväskylä. 
- European Training Foundation. (2020a). International trends and innovation in career guidance - Volume I. Thematic chapters. https://www.etf.europa.eu/en/ publications-and-resources/publications/international-trends-and-innovationcareer-guidance- 0

- European Training Foundation. (2020b). International trends and innovation in career guidance - Volume II. Country case studies. https://www.etf.europa.eu/ en/publications-and-resources/publications/international-trends-andinnovation-career-guidance-volume

- Herr, E.L. (1997). Perspectives on Career Guidance and Counselling in the 21st Century. Educational and Vocational Guidance Bulletin, 60, 1-15.

- Hooley, T. (2020). Why a social justice informed approach to career guidance matters in the time of Coronavirus. Career guidance for social justice. https:// careerguidancesocialjustice.wordpress.com/2020/03/23/why-a-social-justiceinformed-approach-to-career-guidance-matters-in-the-time-of-coronavirus/

- International Centre for Career Development and Public Policy (ICCDPP). (2019). Communiqué 2019. Leading career development services into an uncertain future: Ensuring access, integration and innovation. ICCDPP International Symposium Norway 2019.

- Jarvis, P.S., \& Keeley, E.S. (2003). From vocational decision making to career building: Blueprint, real games, and school counselling. Professional School Counselling, 6, 244-250.

- Kettunen, J. (2017). Career practitioners' conceptions of social media and competency for social media in career services (Doctoral dissertation). University of Jyväskylä, Finnish Institute for Educational Research.

- Ministry of National Education Turkey. (2018). Turkey's Education Vision 2023. http://2023vizyonu.meb.gov.tr/doc/2023_VIZYON_ENG.pdf

- Nagel, D.M., \& Anthony, K. (2016). Using chat and instant messaging (IM) to enrich counsellor training and supervision. In S. Goss, K. Anthony, L.S. Stretch \& D.M. Nagel (Eds.), Technology in mental health: Applications in practice, supervision and training (2nd ed., pp. 242-247). CC Thomas.

- Neary, S., \& Dodd, V. (2016). Understanding career management skills: findings from the first phase of the CMS LEADER project. University of Derby.

https://derby.openrepository.com/bitstream/handle/10545/595866/Understanding+ career+management+skills+Final+Feb+20161.pdf;jsessionid=188F49E442671813C247C145 B905BEDE?sequence=1

- Oomen, A. (2019). Involving parents in careers work in secondary education: an educational innovation.

https://www.researchgate.net/publication/332013812_Involving_parents_ in_careers_work_in_secondary_education_an_educational_innovation

- Plant, P. (2014). Green Guidance. In G. Arulmani, A. Bakshi, F. Leong \& A. Watts (Eds), Handbook of career development: international perspectives. Springer. 
- Solberg, V.S. (2017). Career and workforce development and its role in maintaining a competitive global economy. In V.S. Solberg \& R.S. Ali (Eds.), The handbook of career and workforce development. Research, practice and policy. Routledge Taylor and Francis Group.

- Watts, A.G. (1986). The role of the computer in careers guidance. International Journal for the Advancement of Counselling, 9(2), 145-158. https://doi.org/10.1007/BF00129409

- Watts, A.G. (1996). Computers in guidance. In A.G. Watts, B. Law, J. Killeen, J.M. Kidd \& R. Hawthorn (Eds.), Rethinking careers education and guidance: Theory, policy and practice. Routledge.

- Watts, A.G. (2010). Policy issues relating to the use of ICT in lifelong guidance. Journal of the National Institute for Career Education and Counselling, 25, 33-39.

- Zelloth, H. (2009). In demand: Career guidance in EU neighbouring countries. Office for Official Publications of the European Communities. 


\section{Evaluarea PISA în România}

PISA (Programme for International Student Assessment) este un studiu comparativ interna ional ini iat de către Organiza ia pentru Cooperare şi Dezvoltare Economică (OCDE), cu scopul de a măsura dezvoltarea competen elor de bază ale elevilor de 15 ani, în trei domenii principale: lectură, matematică şi ştiin e. PISA este o evaluare interna ională standardizată care se adresează elevilor cu vârsta de 15 ani.

Ini iată în anul 2000, evaluarea PISA s-a desfăşurat din trei în trei ani, fiecare ciclu de evaluare având un domeniu principal (lectură, matematică sau ştiin e) şi un domeniu de testare nou (de exemplu, competen ele globale, gândirea creativă, domeniul inovativ etc.)

Evaluarea PISA pune accent pe competen ele necesare pentru via a personală, socială sau pentru integrarea pe pia a muncii - cu alte cuvinte accentul nu cade neapărat pe ceea ce ştiu elevii, ci pe aplicarea cunoştin elor în situa ii concrete de via ă.

Evaluarea PISA nu este comprehensivă, adică nu testează toate rezultatele învă ării, toate achizi iile elevilor în preajma finalizării învă ământului obligatoriu, ci vizează un set de competen e definite în cadrul de referin ă, la nivel interna ional, pentru fiecare domeniu de testare.

Administrarea evaluării PISA se realizează sub coordonarea unui consor iu interna ional, pregătirea şi adaptarea la nivelul fiecărei ări participante a instrumentelor de evaluare fiind realizată de un centru na ional, desemnat de Ministerul Educa iei. România este una din cele peste 80 de ări care iau parte la evaluarea PISA. În România, începând cu PISA 2018, coordonarea a fost realizată de Unitatea de Cercetare în Educa iei (în trecut, Institutul de Ştiin e ale Educa iei) din cadrul Centrului $\mathrm{Na}$ ional de Politici în Educa ie, ciclurile anterioare fiind coordonate de fostul Centru $\mathrm{Na}$ ional de Evaluare şi Examinare. 
În România, etapa de pretestare PISA 2022 a avut loc în perioada 4 mai - 4 iunie 2021. La pretestare au participat 43 de şcoli din România şi 2221 de elevi care au sus inut evaluarea computerizată, cu o rată de participare de $94,7 \%$. Evaluarea a presupus rezolvarea de teste cognitive din domeniile matematică, ştiin e, lectură şi gândire creativă, cât şi oferirea de răspunsuri la două chestionare: chestionarul general al elevului şi chestionarul privind TIC.

În perioada 40 aprilie - 30 mai se va desfăşura faza principală a acestei cercetări, care implică evaluarea unui eşantion reprezentativ alcătuit din 7350 de elevi din 180 de şcoli, dintre care 1050 de elevi care înva ă în limba maghiară.

Pregătirea acestei faze implică realizarea activită ilor specifice, în acord cu calendarul interna ional, precum: revizuirea instrumentelor de test în limbile română şi maghiară; testarea sistemului de administrare; pregătirea datelor şi informa iilor necesare alcătuirii eşantionului reprezentativ în conformitate cu reglementările metodologice impuse de studiu; adaptarea şi revizuirea manualelor şi formularelor specifice pentru administrare; formarea administratorilor de test; formarea monitorilor de calitate na ionali; comunicarea şi colaborarea cu şcolile pentru pregătirea administrării.

Datele colectate sunt valoroase pentru faptul că permit raportarea la cerin ele actuale legate de nivelul de pregătire aşteptat într-o societate globalizată, prin realizarea de compara ii la nivel interna ional, ceea ce atrage după sine şi posibilitatea de a lua decizii în timp real în scopul creşterii eficien ei actului educa ional. 


\section{BOARD OF DIRECTORS:}

Researcher Mihai JIGĂU, PhD. Institute of

Educational Sciences, Romania

Prof. emeritus Viorel NICOLESCU, PhD.

University of Bucharest, Romania

Prof. Constantin CUCOȘ, PhD. "Alexandru

Ioan Cuza" University of lași, Romania
REVISTA

DE

PEDAGOGIE
JOURNAL OF

PEDAGOGY

\section{EDITORIAL BOARD:}

Prof. Gabriel ALBU, PhD. Petroleum-Gas University of Ploiești, Romania

Researcher Otilia APOSTU, PhD. N.C.P.E.E. - E.R.U.*, Romania

Alexandru BOBOC, PhD. Romanian Academy

Researcher Laura Elena CĂPITĂ, PhD. N.C.P.E.E. - E.R.U. ${ }^{*}$, Romania

Prof. Carmen CRETTU, PhD. "Alexandru Ioan Cuza" University of lași, Romania

Lecturer Alina Narcisa CRIȘAN, PhD. Tehnical University of Cluj-Napoca, Romania

Senior lecturer Roxana ENẢCHE, PhD. Vice-President, Association "Teachers' Academy”, Romania

Prof. Irfan ERDOGAN, PhD. University of Istanbul, Turkey

Prof. Natasha Angelska GALEVSKA, PhD. "Cyiril and Methodius" University of Skopje, Macedonia

Prof. Dimitrios B. GOUDIRAS, PhD. University of Macedonia, Thessaloniki, Greece

Researcher Atwell GRAHAM, PhD. University of Wales, United Kingdom

Researcher Irina HORGA, PhD. N.C.P.E.E. - E.R.U.*, Romania

Prof. Violeta MIRCHEVA, PhD. National Institute of Education, Bulgaria

Prof. Ioan NEACŞU, PhD. University of Bucharest, Romania

Prof. Rodica NICULESCU, PhD. "Transilvania” University of Brașov, Romania

Prof. Aleksandra PEJATOVIC, PhD. University of Belgrad, Serbia

Prof. Rossitsa PENKOVA, PhD. "K. Ohridski" University of Sofia, Bulgaria

Lecturer Ana-Maria Aurelia PETRESCU, PhD. "Valahia" University of Târgoviște, Romania

Prof. Dan POTOLEA, PhD. University of Bucharest, Romania

Prof. Athina SIPITANOU, PhD. University of Macedonia, Thessaloniki, Greece

Prof. Emil STAN, PhD. Petroleum-Gas University of Ploiești, Romania

Acad. Alexandru SURDU, Romanian Academy

Prof. Nikos TERZIS, PhD. "Aristotle" University of Thessaloniki, Greece

Researcher Simona Luciana VELEA, PhD. N.C.P.E.E. - E.R.U.*, Romania

Prof. Pavel ZGAGA, PhD. University of Ljubljiana, Slovenia

${ }^{*}$ National Center for Policy and Evaluation in Education - Education Research Unit

\section{ISSUE COORDINATOR:}

Researcher Delia GOIA

\section{EDITOR:}

Miruna Luana MIULESCU

\section{GRAPHIC DESIGNER AND DTP:}

Vlad PASCU

\section{JOURNAL BINDING:}

Constantin CHIȚU

Print ISSN: 0034-8678

Online ISSN: 2559-639X

Indexing: CEEOL, Citefactor, Crossref, De Gruyter (IBZ and IBR), DOAJ, EBSCO, ERIHPlus, Google Academic, ROAD and Ulrichweb. The articles on Higher Education can also be indexed in HEDBIB.

The information and views set out in the published contributions are those of the author(s) and do not necessarily reflect the official opinion of the Journal of Pedagogy.

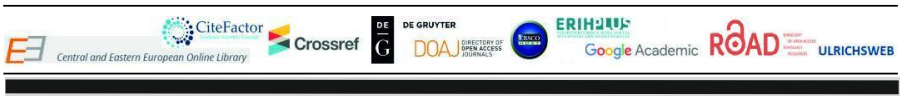

CONTACT: 37 Ştirbei Vodă Street, sector 1, Bucharest 010102

Tel.: 004021 314.27.83 Fax: 004021312.14 .47

E-mail: revped@ise.ro Webpage: http://revped.ise.ro

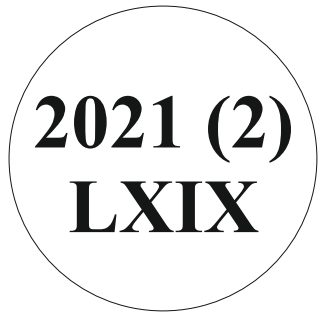




\section{STIMAȚI CITITORI,}

Revista de pedagogie își propune, ca și până acum de altfel, să popularizeze rezultatele cercetării științifice în domeniul educației la nivel național și internațional, să dezbată puncte de vedere și aspecte de actualitate din domenii precum management școlar, curriculum, evaluare, educație permanentă, consilierea și orientarea carierei. Revista contribuie astfel la facilitarea schimbului de experiență și la consolidarea pregătirii riguroase și consecvente a resurselor umane din domeniul educației.

Revista de pedagogie reprezintă o sursă valoroasă de documente care trebuie să facă parte din biblioteca profesorilor, a tinerilor care se pregătesc pentru cariera didactică și a celor interesați de progresele, direcțiile de dezvoltare, inovațiile și bunele practici în domeniul educațional.

Vă informăm că redacția dispune, pentru consultare, de colecția Revistei de pedagogie pe anii 1995-2015, precum și, pentru vânzare, de diferite numere din perioada 2010-2020.

Pentru informații suplimentare privind prețul unui exemplar al Revistei de pedagogie și modalitățile de achiziționare vă stăm la dispoziție la sediul revistei din strada Știrbei Vodă nr. 37, sector 1 , București, tel.: 021-3142783, e-mail: revped@ise.ro, http://revped.ise.ro.

Vă mulțumim,

REDACTIIA

\section{Revista de Pedagogie/Journal of Pedagogy $2021(2) \cdot$ LXIX \\ Print ISSN: 0034-8678 \\ Online ISSN: 2559-639X}

